Aus der Klinik für Kinder- und Jugendmedizin Abteilung Pädiatrische Hämatologie und Onkologie

(Prof. Dr. med. C. Kramm)

im Zentrum Kinderheilkunde und Jugendmedizin

der Medizinischen Fakultät der Universität Göttingen

\title{
Expressionshemmung von MCM3 in Glioblastomen durch RNA-Interferenz
}

\author{
INAUGURAL - DISSERTATION
}

zur Erlangung des Doktorgrades

der Medizinischen Fakultät der

Georg-August-Universität zu Göttingen

vorgelegt von

Peter Lauerer

aus

Furth im Wald

Göttingen 2014 
Dekan: Prof. Dr. rer. nat. H. K. Kroemer

I. Berichterstatter: Prof. Dr. med. M. Lakomek

II. Berichterstatter/in: Prof. Dr. rer. nat. H. D. Bastians

III. Berichterstatter/in: Prof. Dr. med. G. Wulf

Tag der mündlichen Prüfung: 18.03 .2015 


\section{Inhaltsverzeichnis}

1 Einleitung........................................................................................................................... 1

1.1 Übersicht und Klassifikation von Gliomen ........................................................ 1

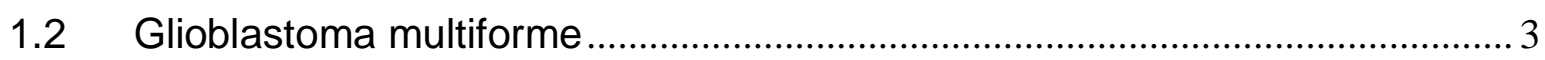

1.3 Minichromosome maintenance-Proteine und minichromosome maintenance-Protein 3 ................................................................................ 7

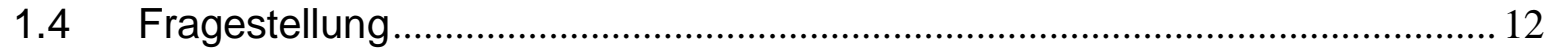

2 Materialien und Methoden.............................................................................................. 13

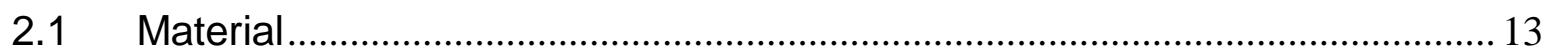

2.1.1 Zelllinie und Medien ............................................................................... 13

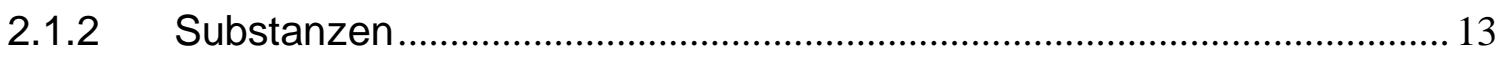

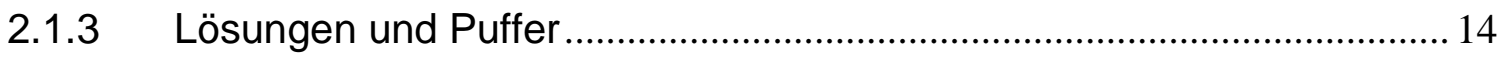

2.1.4 Verbrauchsmaterialen ........................................................................ 14

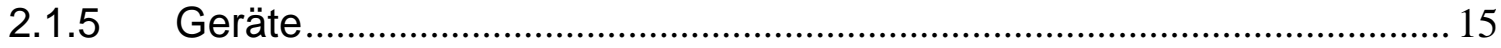

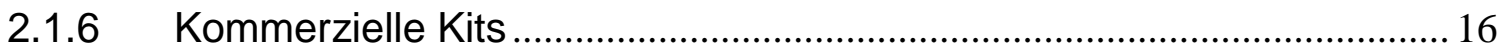

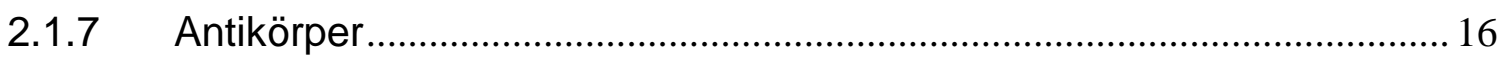

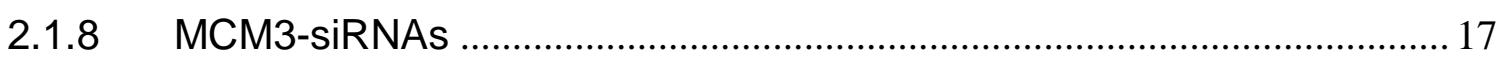

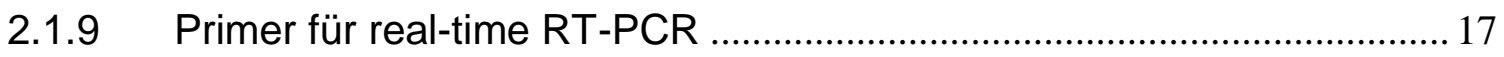

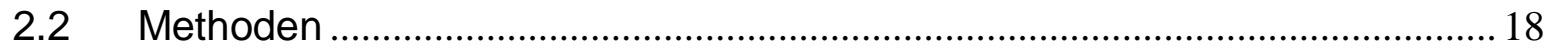

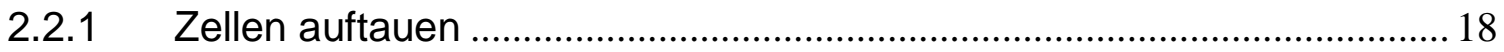

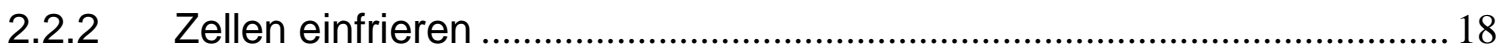

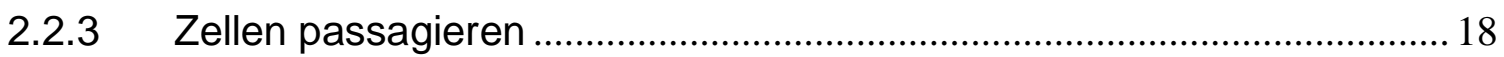

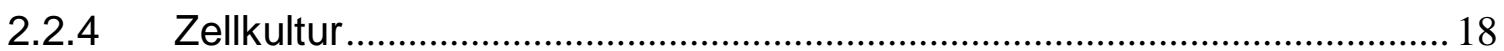

2.2.5 Zellen ernten und Herstellung von Zelllysaten......................................... 19

2.2.6 Zellzählung mittels Neubauer-Zählkammer............................................... 19

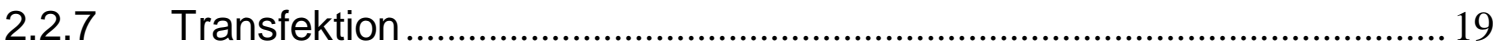

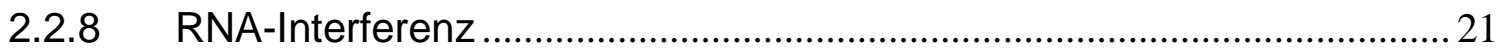

2.2.9 Proteinbestimmung mittels Lowry-Assay .............................................. 24

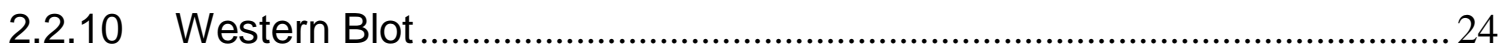

2.2.11 Überprüfung der Stoffwechselaktivität mittels MTT-Test ........................ 28

2.2.12 Proliferationsuntersuchung mittels BrdU-Assay …………………...........29 
2.2.13 Bestimmung der Zellzahl und Zellvitalität durch Zellzählung mit

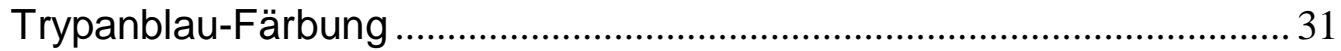

2.2.14 Untersuchung auf Apoptose mittels Cell Death Detection ELISA ..........32

2.2.15 Apoptoseuntersuchung mittels cleaved Caspase-3 Western Blot.......... 33

2.2.16 Zellzyklusanalyse mittels FACS-Analyse mit Propidiumiodid................... 34

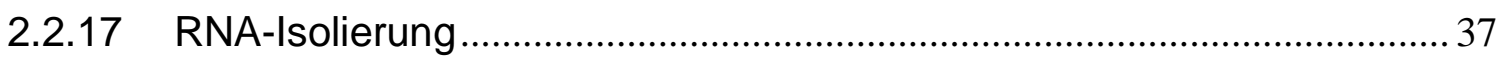

2.2.18 RNA-Konzentrationbestimmung mittels NanoDrop.....................................38

2.2.19 Real-time Polymerase-Kettenreaktion zur Bestimmung der Expressionshemmung von MCM3-mRNA .................................................. 39

2.2.20 Überprüfung des Langzeitüberlebens mittels Clonogenic Assay ........... 43

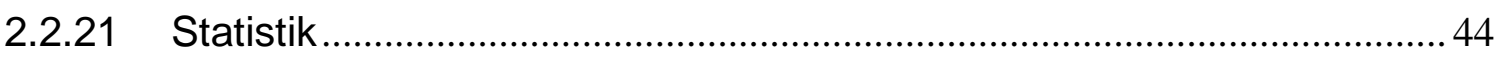

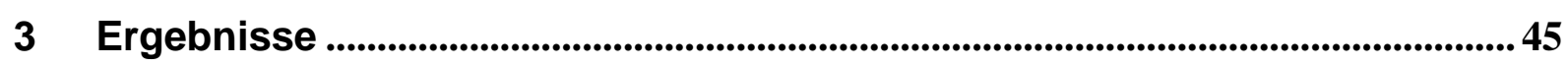

3.1 MCM3-Suppression in U87MG-Zellen durch MCM3-siRNA 13 und MCM3SiRNA 15

3.2 Stoffwechselaktivität der U87MG-Zellen nach Behandlung mit MCM3siRNA 13 und 15 im MTT-Test

3.3 Proliferation der U87MG-Zellen bei Behandlung mit MCM3-siRNA 13 und 15 im BrdU-Assay....

3.4 Trypanblau-Färbung der U87MG-Zellen nach Transfektion mit MCM3siRNA 13 und 15 zur Bestimmung der Zellzahl und Vitalität

3.5 Messung der Apoptoserate nach Behandlung der U87MG-Zellen mit MCM3-siRNA 13 und 15 im Cell Death Detection ELISA....

3.6 Überprüfung der Apoptoseinduktion im cleaved Caspase-3 Western Blot .. 56

3.7 Zellzyklusanalyse mittels FACS-Analyse mit Propidiumiodid .56

3.8 Überprüfung der MCM3-mRNA-Suppression nach Transfektion der U87MG-Zellen mit MCM3-siRNAs mittels real-time RT-PCR

3.9 Langzeituntersuchung der Wirkung von MCM3-Suppression auf die Klonzahl mittels Clonogenic Assay

4 Diskussion

4.1 Starke Suppression von MCM3 auf Proteinebene

4.2 Verminderung der Stoffwechselaktivität und Proliferation durch MCM3Suppression

4.3 MCM3-Suppression bewirkt einen Proliferationsstopp mit Zellzyklusarrest, aber keine Apoptose 
4.4 Bestimmung der MCM3-mRNA-Spiegel in der kinetischen Untersuchung von MCM3-siRNA-behandelten Zellen mittels real-time RT-PCR. 65

4.5 MCM3 ist ein geeignetes Angriffsziel in der Glioblastomtherapie .................66 66

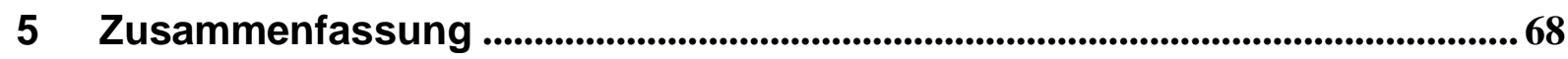

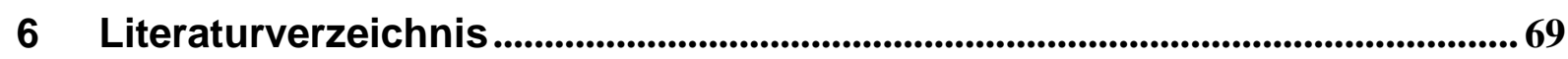




\section{Einleitung}

\section{1 Übersicht und Klassifikation von Gliomen}

Im zentralen Nervensystem (ZNS) spielen zwei verschiedene Zellarten eine wichtige Rolle. Die erste Zellart, die Nervenzellen oder Neurone, sind über Synapsen miteinander verbunden und leiten elektrische Impulse weiter. Die zweite Zellart, die Gliazellen, bilden im ZNS die größte Zellpopulation. Rudolf Virchow beschrieb die Gliazellen erstmalig 1858. Er nahm an, dass es sich um Hilfszellen handelt, die Nervenzellen als eine Art Leim verbinden. Deshalb nannte er diese Zellen Nervenkitt oder Neuroglia (Glia, griechisch = Kitt, Leim). Gliazellen haben wichtige Aufgaben wie z.B. die elektrische Isolation der Neurone.

Mit der Entdeckung der Gliazellen und den fortlaufend verbesserten histologischen Untersuchungsmethoden konnten die Hirntumoren dann auch nach ihrem zu Grunde liegenden Ursprungsgewebe erstmalig einer Einteilung unterzogen werden (Virchow 1864). Diese erste Einteilung der Hirntumoren erstellte Virchow 1864. Zuvor existierten nur Einzelbeschreibungen von „Gehirnverhärtungen“, die deskriptive Begriffe wie "Gehirnkrebse“ oder „knorpelige Geschwülste“ verwendeten (Bressler 1839). Virchows Einteilung war bis in das 20. Jahrhundert die Basis für die nachfolgenden Klassifikationen.

Primäre Tumoren des zentralen Nervensystems bestehen aus einer heterogenen Gruppe benigner und maligner Neoplasien, von denen die meisten Tumoren glialen Ursprungs sind und deshalb als Gliome bezeichnet werden (Ohgaki und Kleihues 2005 a). Die Gliome werden je nach dem ursprünglichen glialen Zelltyp weiter in astrozytäre, oligodendrozytäre und ependymale Gruppen sowie in Mischformen dieser Gruppen unterteilt (Kleihues et al. 2002).

Insgesamt 30-40 \% aller intrakraniellen Tumoren sind Gliome. Gliome treten typischerweise im mittleren Alter auf. Der Erkrankungsgipfel liegt zwischen 40 und 65 Jahren (Schneider et al. 2010).

Ende der 1970er Jahre wurden Gliome von der Weltgesundheitsorganisation (WHO) erstmals weltweit einheitlich klassifiziert. Die Klassifikation umfasste vier Malignitätsgrade (WHO-Grad I - IV). Mit Hilfe dieser Einteilung, die bereits mehrfach überarbeitet wurde, ist es möglich, zuverlässige Aussagen über das biologische und klinische Verhalten von Gliomen, sowie über die Langzeitüberlebenschancen eines Patienten zu treffen (Louis et al. 2007). 
In der aktuellen Klassifikation der WHO von 2007 (Tabelle 1) wird unterschieden zwischen den niedriggradigen, benignen Gliomen (WHO-Grad I), die vor allem bei Kindern auftreten und diffus infiltrierenden Astrozytomen (WHO-Grad II - IV), die vor allem bei Erwachsenen vorkommen. WHO-Grad II-Gliome können die Tendenz haben, sich zu einem WHO-Grad III und letztendlich zu einem sekundären Glioblastom des WHO-Grades IV zu entwickeln, wobei die meisten der Glioblastome primäre Tumoren sind (Riemenschneider und Reifenberger 2009).

\begin{tabular}{|l|c|}
\hline Tumortyp & WHO-Grad \\
\hline pilozytisches Astrozytom, subependymales Riesenzellastrozytom & I \\
\hline diffuses Astrozytom, Ependymon, Oligoastrozytom, Oligodendrogliom & II \\
\hline $\begin{array}{l}\text { anaplastisches Astrozytom, anaplastisches Oligoastrozytom, } \\
\text { anaplastisches Oligodendrogliom }\end{array}$ & III \\
\hline Glioblastom & IV \\
\hline
\end{tabular}

Tabelle 1: WHO-Klassifikation der Gliome von 2007.

Patienten mit niedriggradigen Gliomen wie z.B. einem Astrozytom Grad I haben nach vollständiger Resektion eine sehr gute Prognose. Bei Patienten mit höhergradigen Astrozytomen oder mit einem Glioblastoma multiforme ist die Prognose deutlich schlechter (Tabelle 3). Der Fokus dieser Arbeit liegt auf dem hochmalignen Glioblastoma multiforme. 


\subsection{Glioblastoma multiforme}

Das Glioblastoma multiforme ist der häufigste und aggressivste primäre Hirntumor im Erwachsenenalter mit einer jährlichen Inzidenz von 3,17 Fällen pro 100.000 Einwohner in den USA (Tabelle 2) (Schneider et al. 2010) und 3,55 Fällen pro 100.000 Einwohner in Europa (Ohgaki und Kleihues 2005 b) mit einer geschlechts-spezifischen Verteilung von 1,33: 1 (männlich zu weiblich).

\begin{tabular}{|l|c|c|c|}
\hline \multicolumn{1}{|c|}{ Tumortyp } & WHO-Grad & $\begin{array}{c}\text { Anteil aller } \\
\text { Hirntumoren (\%) }\end{array}$ & $\begin{array}{c}\text { Inzidenz } \\
\text { (100.000 pro Jahr) }\end{array}$ \\
\hline pilozytisches Astrozytom & I & 0,17 & 0,33 \\
\hline diffuses Astrozytom & II & 0,5 & 0,09 \\
\hline Oligodendrogliom & II & 1,4 & 0,27 \\
\hline anaplastisches Astrozytom & III & 2,1 & 0,4 \\
\hline $\begin{array}{l}\text { anaplastisches } \\
\text { Oligodendrogliom }\end{array}$ & III & 0,7 & 0,12 \\
\hline Glioblastom & IV & 17,1 & 3,17 \\
\hline
\end{tabular}

Tabelle 2: Häufigkeit von verschiedenen Gliomen aus dem Central brain tumor registry of the United States (http://www.cbtrus.org).

Das mittlere Alter bei Diagnosestellung beträgt 62 Jahre. Die Bezeichnung dieses Tumors als Glioblastoma multiforme erfolgte aufgrund des zu Grunde liegenden Zelltyps und des sehr variablen Erscheinungsbildes aus Nekrosen, Einblutungen und zum Teil auch Zysten (Abbildung 1).

A

B

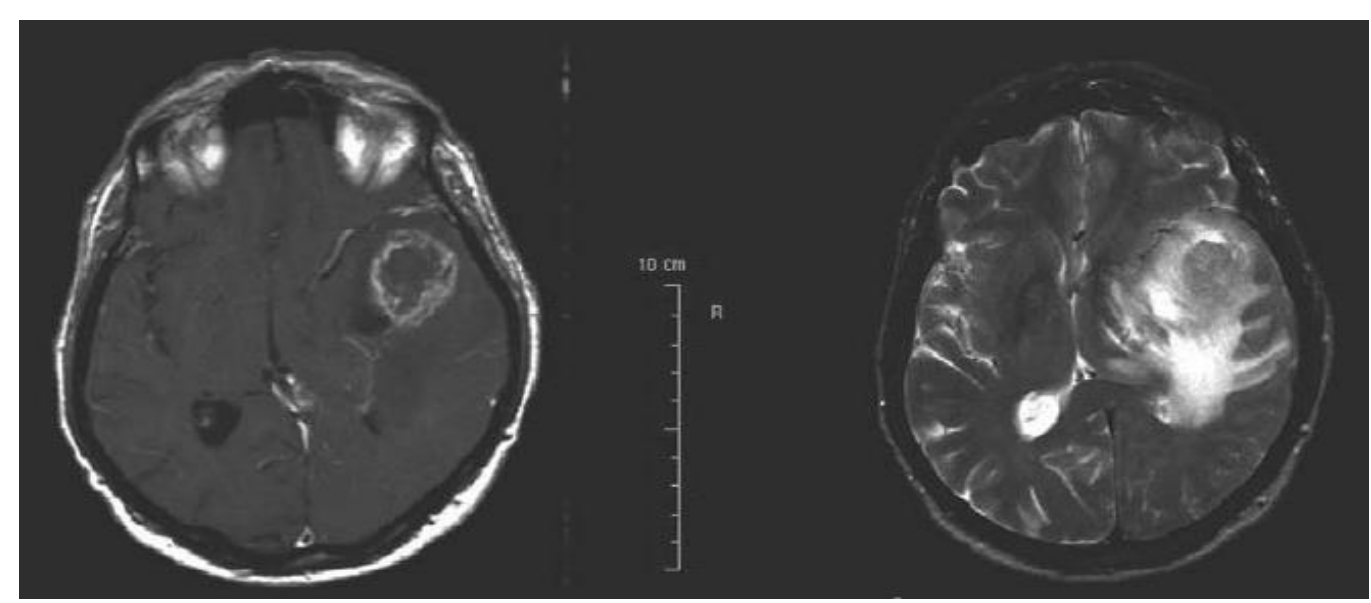

Abbildung 1: MRT-Aufnahme eines Glioblstoms mit zentralnekrotischem Bereich und ausgeprägtem perifokalem Ödem: A) T1-Wichtung mit Kontrastmittel, B) T2Wichtung mit deutlicher Ödemdarstellung. Modifiziert nach Schneider et al. 2010, S. 801. 
Das Glioblastoma multiforme ist ein gering differenzierter Tumor, der in der WHOKlassifikation als Grad IV eingestuft wird. Makroskopisch zeigen Glioblastome ein typisches buntes Bild aus Blutungen und Nekrosen. Des Weiteren sind insbesondere eine starke Vaskularisierung und die diffuse Invasion in das benachbarte Hirngewebe typisch für das Glioblastom. Obwohl der Tumor makroskopisch oft gut abgrenzbar erscheint, wächst er histologisch infiltrativ und diffus in das angrenzende Hirngewebe. Histologisch besteht eine hohe Zelldichte mit einer deutlichen zellulären und nukleären Polymorphie. Es sind sowohl multinukleäre Riesenzellen als auch kleinzellige Formen beschrieben, die eine hohe mitotische Aktivität mit patho-logischen Mitosen zeigen. Charakteristisch für Glioblastome und des Weiteren ein Unterscheidungskriterium zu anaplastischen Astrozytomen ist der Nachweis von Nekrosen mit Bildung von Pseudopalisaden (Claes et al. 2007). Pseudopalisaden sind perifokale Zelldichtesteigerungen, die die nekrotischen Bereiche umgeben.

Glioblastome liegen meist supratentoriell und sind oft in der Nähe des Marklagers lokalisiert. Obwohl auf dem Gebiet der Glioblastome in den letzten Jahrzehnten intensive Forschungen betrieben wurden, ist keine signifikante Verbesserung der Therapie eingetreten und somit auch keine deutlich verbesserten Überlebensraten von Patienten mit einem Glioblastom. Die prognostische Überlebenszeit für Patienten mit einem Glioblastoma multiforme beträgt ohne Therapie meist nur einige Monate (Ohgaki und Kleihues 2005 b) (Tabelle 3).

\begin{tabular}{|l|c|c|c|}
\hline \multicolumn{1}{|c|}{ Tumor } & $\begin{array}{c}\text { mittleres Alter bei } \\
\text { Diagnosestellung } \\
\text { (Jahre) }\end{array}$ & $\begin{array}{c}\text { 2-Jahres- } \\
\text { Überleben } \\
\text { (\%) }\end{array}$ & $\begin{array}{c}\text { 5-Jahres- } \\
\text { Überleben } \\
\text { (\%) }\end{array}$ \\
\hline diffuses Astrozytom & 47 & 67 & 49 \\
\hline Oligodendrogliom & 41 & 80 & 63 \\
\hline anaplastisches Astrozytom & 50 & 46 & 31 \\
\hline $\begin{array}{l}\text { anaplastisches } \\
\text { Oligodendrogliom }\end{array}$ & 46 & 61 & 38 \\
\hline Glioblastom & 62 & 9 & 3 \\
\hline
\end{tabular}

Tabelle 3: 2 und 5 Jahre Überlebensraten nach Diagnose eines primären Hirntumors. Modifiziert nach Davis et al. 1999, S. 487. 
Durch multimodale Behandlungsansätze (Tabelle 4) mittels Operation, Radio- und Chemotherapie kann die mittlere Überlebenszeit auf ca. 1 Jahr verlängert werden (Stupp et al. 2005).

\begin{tabular}{|l|c|l|}
\hline \multicolumn{1}{|c|}{ Tumortyp } & WHO-Grad & \multicolumn{1}{c|}{ Therapie } \\
\hline pilozytisches Astrozytom & I & Operation \\
\hline Astrozytom & II & $\begin{array}{l}\text { Operation (oder Biopsie) und wait and } \\
\text { see oder Strahlentherapie }\end{array}$ \\
\hline $\begin{array}{l}\text { anaplastisches Astrozytom, } \\
\text { anaplastisches } \\
\text { Oligodendrogliom }\end{array}$ & III & $\begin{array}{l}\text { Operation (oder Biopsie) und } \\
\text { Chemotherapie (oder Strahlentherapie) }\end{array}$ \\
\hline Glioblastom & IV & $\begin{array}{l}\text { Operation (oder Biopsie) und } \\
\text { Strahlentherapie und Chemotherapie } \\
\text { (Temozolomid) }\end{array}$ \\
\hline
\end{tabular}

Tabelle 4: Primärtherapie unterschiedlicher Gliome nach einer Empfehlung der Neuroonkologischen Arbeitsgemeinschaft (http://www.neuroonkologie.de).

Der stärkste prognostische Faktor ist das Lebensalter bei Diagnosestellung. Je höher das Alter bei Diagnosestellung ist, desto schlechter ist die Prognose für den Patienten (Ohgaki und Kleihues 2005 a). Einer der entscheidenden Gründe für die schlechte Prognose ist, neben der beschriebenen Lokalisation in der Nähe des Marklagers, die hohe Invasivität der Glioblastomzellen. Dies ist auch einer der Hauptgründe für eine hohe Rate an Rezidiven, die auch bei durchgeführter Behandlung mit Tumorresektion, Radio- und Chemotherapie bis in die kontralaterale Hemisphäre des Gehirns lokalisiert sein können (Abbildung 2).

A

B

C

D

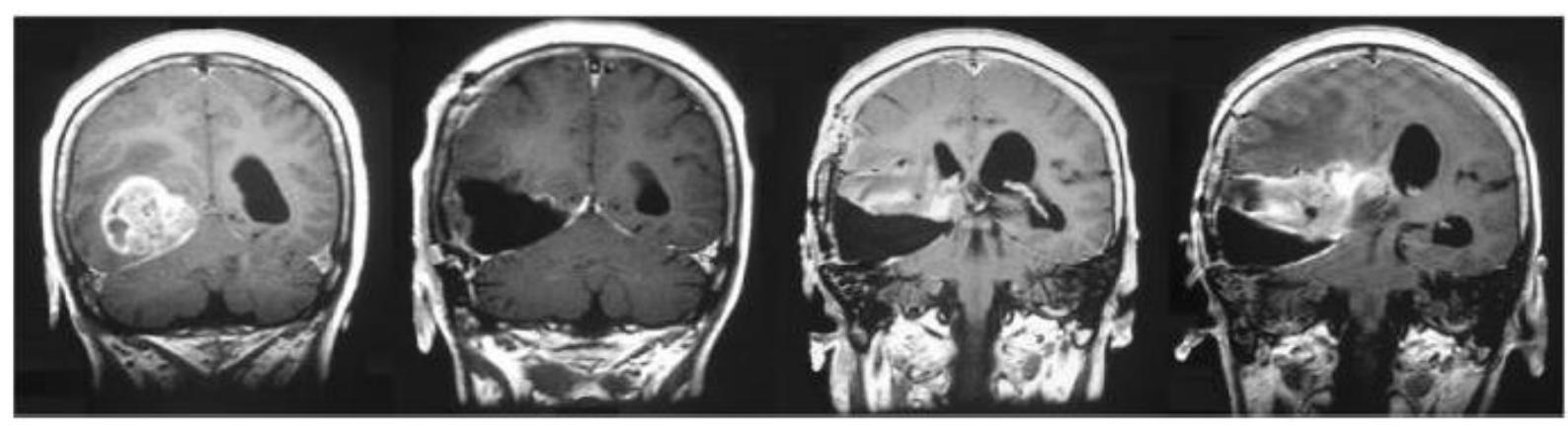

Abbildung 2: Rezidiventwicklung nach Operation. A) Glioblastom bei Diagnosestellung, B) Glioblastom nach Resektion und vor Chemo- und Strahlentherapie, C) Glioblastom mit Rezidiventwicklung nach 12 Monaten, D) Glioblastom nach 17 Monaten kurz vor Tod des Patienten. Modifiziert nach Nakada et al. 2007, S. 459. 
Aktuell gibt es eine Leitlinie der Arbeitsgemeinschaft der wissenschaftlichen medizinischen Fachgesellschaften (AWMF) von 2011 aus dem Fachbereich Neurologie für die Behandlung von Gliomen und eine Leitlinie der Neuroonkologischen Arbeitsgemeinschaft zur Behandlung von Gliomen aus dem Jahr 2008.

Das Ausmaß der operativen Resektion wird als wichtiger positiver Indikator für die weitere Überlebenszeit angesehen (Stummer et al. 2006). Deshalb ist die möglichst komplette makroskopische Resektion, welche aufgrund der Tumorlokalisation oft nicht möglich ist, ein wichtiger erster Therapieschritt im multimodalen Behandlungskonzept. Eine Multicenterstudie zeigte, dass Patienten, bei denen kurz nach der Operation keine Kontrastmittel aufnehmenden Tumorreste mehr mit Hilfe der Magnetresonanztomographie nachweisbar waren, signifikant länger überleben (16,7 Monate im Vergleich zu 11,8 Monaten) (Stummer et al. 2006).

Die Stellung der Indikation zur Operation und die Radikalität der Resektion sind von der Tumorlokalisation abhängig, da die Vermeidung therapiebedingter neuro-logischer Defizite eine höhere Priorität hat als die Radikalität der Operation. Die Reduktion der Tumormasse und die Probengewinnung für die histologische Untersuchung sind dann die primären Ziele.

Eine an den operativen Schritt anschließende Strahlentherapie, konzentriert auf das Tumorzielvolumen, verlängert die mediane Überlebenszeit (Laperriere et al. 2002). Des Weiteren wird eine die Strahlentherapie begleitende Chemotherapie mit Temozolomid empfohlen (Stupp et al. 2005, Stupp und Hottinger 2008). Dieses Vorgehen erhöht die Überlebenszeit von 12,1 auf 14,6 Monate und die 2-JahresÜberlebensrate um $16 \%$ von $10 \%$ auf $26 \%$. Weiterhin konnte gezeigt werden, dass Patienten mit Glioblastomen, bei denen eine Methylierung des O6-Methylguanin-DNAMethyltransferase (MGMT)-Gens nachgewiesen werden kann, besonders gut auf die Chemotherapie mit Temozolomid ansprechen (Hegi et al. 2005). Bei diesen Patienten lag die 2-Jahres-Überlebensrate sogar bei $46 \%$.

Neuere Untersuchungen zur Effektivität zielgerichteter molekulargenetischer Therapeutika, die entwickelt wurden, wie z.B. Inhibitoren des epidermal growth factor receptor, Gefitinib oder Erlotinib, Inhibitoren der Integrine wie Cilengitide und der Tyrosinkinase wie Imatinib konnten bisher keine deutliche Verbesserung der Therapie oder des Überlebens der Patienten belegen (Minniti et al. 2009).

Aufgrund der sehr schlechten Prognose und der ausbleibenden Therapieverbesserungen ist eine weiterführende Erforschung neuer Therapieoptionen von großer Bedeutung. 
Ein Ansatzpunkt könnte die Suppression von zellzyklusassoziierten Genen der Tumorzellen darstellen. Mögliche Zielproteine stellen bei Glioblastomen die an der Replikation beteiligten Bestandteile des minichromosome maintenance-Komplexes dar (Soeling et al. 2005).

\subsection{Minichromosome maintenance-Proteine und minichromosome maintenance-Protein 3}

Die minichromosome maintenance-Proteine (MCM-Proteine) wurden ursprünglich bei genetischen Analysen von Saccharomyces cerevisiae-Mutanten (Hefe) im Zellzyklus identifiziert (Maine et al. 1984). Nach dieser Entdeckung wurden in vielen anderen Spezien homologe Proteine identifiziert.

Die MCM-Proteine spielen bei der DNA-Replikation sowohl bei der Initiation als auch bei der Elongation eine wichtige Rolle. Insgesamt sind 10 verschiedene Subtypen, MCM 1-10, bekannt. Die Zellteilung eukaryotischer Zellen findet im Zellkern statt, dort wird die DNA repliziert. Findet keine Replikation statt, ist die DNA in zwei Strängen ineinander gewunden. Zu Beginn der Replikation wird die DNA an den Replikationsorten lokal entwunden. Ein essentieller Bestandteil der Replikation ist der Präreplikationskomplex. An diesem sind auch die MCM-Proteine beteiligt. Für die Rekrutierung der MCM-Proteine an den Präreplikationskomplex (Abbildung 3) ist die funktionale Interaktion von Origin recognition complex (ORC), cell division cycle 6Proteinen (Cdc6) und cell division cycle 10 dependent transcript 1 (Cdt1) eine wichtige Voraussetzung (Maiorano et al. 2006, Schwacha und Bell 2001). 


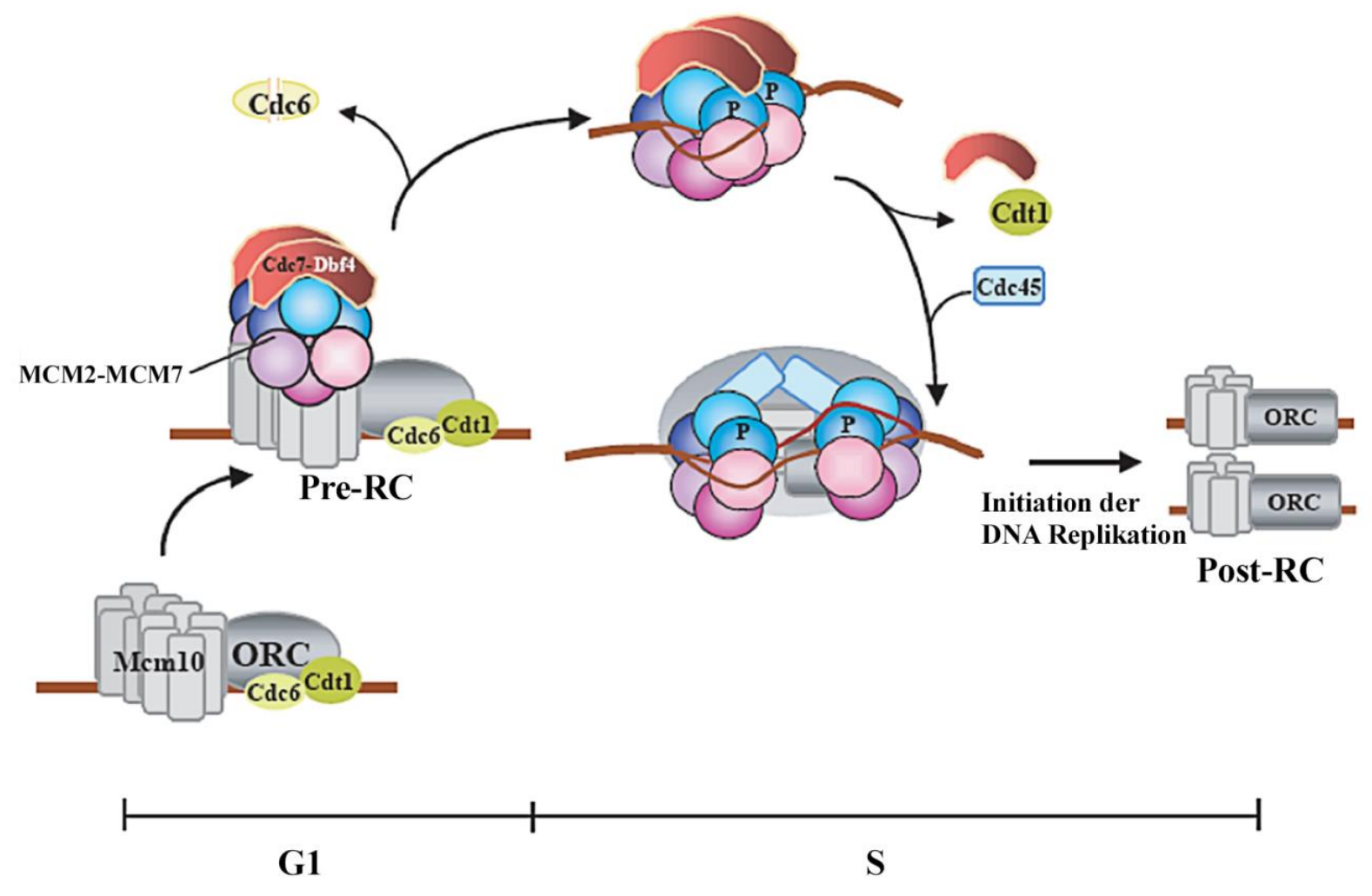

Abbildung 3: Präreplikationskomplex vor Initiation der DNA Replikation. Modifiziert nach Lei und Tye 2001, S. 1448.

Zunächst bindet der Präreplikationskomplex, bestehend aus ORC, Cdc6 und Cdt1 und MCM 2-7, in der G1-Phase des Zellzyklus an die DNA. Durch die Helikase-Aktivität des Präreplikationskomplexes kommt es zur Entwindung der DNA. Dieser Abschnitt wird Replikationsgabel genannt. An der entstandenen Replikationsgabel können nun DNA-Polymerasen und andere wichtige Bestandteile binden und die DNA-Elongation durchführen (Lei und Tye 2001).

Bei den meisten Lebewesen sind die MCM-Proteine für die Dauer des gesamten Zellzyklus im Kern lokalisiert (Kearsey und Labib 1998, Tye 1999). Während sie in der G1-Phase der Mitose an der Origin-DNA lokalisiert sind, lösen sie sich in der S-Phase zunehmend vom Chromatin ab (Aparicio et al. 1997, Hendrickson et al. 1996), so dass die DNA pro Zellzyklus nur einmal repliziert wird. Die Reassoziation von MCM 2-7 kann erst wieder nach erfolgter Mitose stattfinden (Lei und Tye 2001).

Die Regulation der MCM2-7-Aktivität erfolgt über Phosphorylierung durch Kinasen, wodurch die S-Phase und die Dissoziation der MCMs vom Chromatin eingeleitet wird (Masai et al. 2000).

Im Gegensatz zu den ORC-Proteinen und Cdc6 liegen die MCM-Proteine in einer viel größeren Anzahl als benötigt vor. In der Hefe liegen die MCM-Proteine in einem 100500-fachen Überschuss vor (Lei et al. 1996). Die Grundform des MCM-Komplexes 
besitzt einen heterohexameren Aufbau aus allen sechs MCM-Proteinen, der sich in elektronenmikroskopischen Aufnahmen als ringförmige Struktur darstellt. (Kubota et al. 1997). Weiterhin ist beschrieben, dass die MCM-Proteine auch in kleineren Subkomplexen vorliegen können. Diese zeigen im Vergleich zur hexameren Form aber signifikante funktionelle Unterschiede. Für die korrekte Bildung des Präreplikationskomplexes ist ein heterohexamerer Komplex aus allen sechs MCMProteinen nötig (Prokhorova und Blow 2000).

MCM-Proteine können als Indikator für Malignität hilfreich sein, da sie sich nur in teilenden und nicht in ausdifferenzierten Zellen finden (Musahl et al. 1998). Es wurde in der Vergangenheit bereits gezeigt, dass einige der MCM-Proteine als Prognosefaktoren bei verschiedenen onkologischen Erkrankungen eingesetzt werden können. MCM2 ist z.B. ein Prognosemarker bei Brustkrebs (Gonzalez et al. 2003) und beim Harnblasenkarzinom (Korkolopoulou et al. 2005). Des Weiteren wurde die Aussagekraft von MCM6 bei Mantelzell-Lymphomen (Schrader et al. 2005) bereits gezeigt. Eine Überexpression von MCM2, MCM3 und MCM7 konnte in Medulloblastomen gezeigt werden (Lau et al. 2010). MCM3 konnte als Prognosemarker für humane Astro-zytome indentifiziert werden (Soeling et al. 2005). Ebenfalls ist MCM3 ein Marker bei papillären Schilddrüsenkarzinomen (Igci et al. 2014) und Tumoren der Speicheldrüse (Ashkavandi et al. 2013).

MCM3 besitzt ein Molekulargewicht von 105 kDa und besteht aus 808 Aminosäuren, und das korrespondierende Gen ist auf dem kurzen Arm von Chromosom 6. Die Halbwertszeit beträgt in humanen HeLa-Zellen (humane Zervixkarzinom-Epithelzellen) ca. 24 Stunden. (Musahl et al. 1998).

Neben der Beteiligung am Präreplikationskomplex konnte für ein während der Apoptose entstehendes Fragment von MCM3 ein proapoptotischer Effekt gezeigt werden (Schories et al. 2004).

MCM3 wird in humanen Astrozytomen im Vergleich zu normalem Hirngewebe verstärkt exprimiert (Abbildung 4) (Soeling et al. 2005). Des Weiteren konnte gezeigt werden, dass die Höhe der MCM3-Proteinexpression einen prognostischen Wert für Patienten mit anaplastischen Astrozytomen WHO-Grad III besitzt, da eine Überexpression von MCM3 in anaplastischen Astrozytomen mit einer verringerten mittleren Überlebenszeit der Patienten einhergeht (Abbildung 5) (Soeling et al. 2005). 


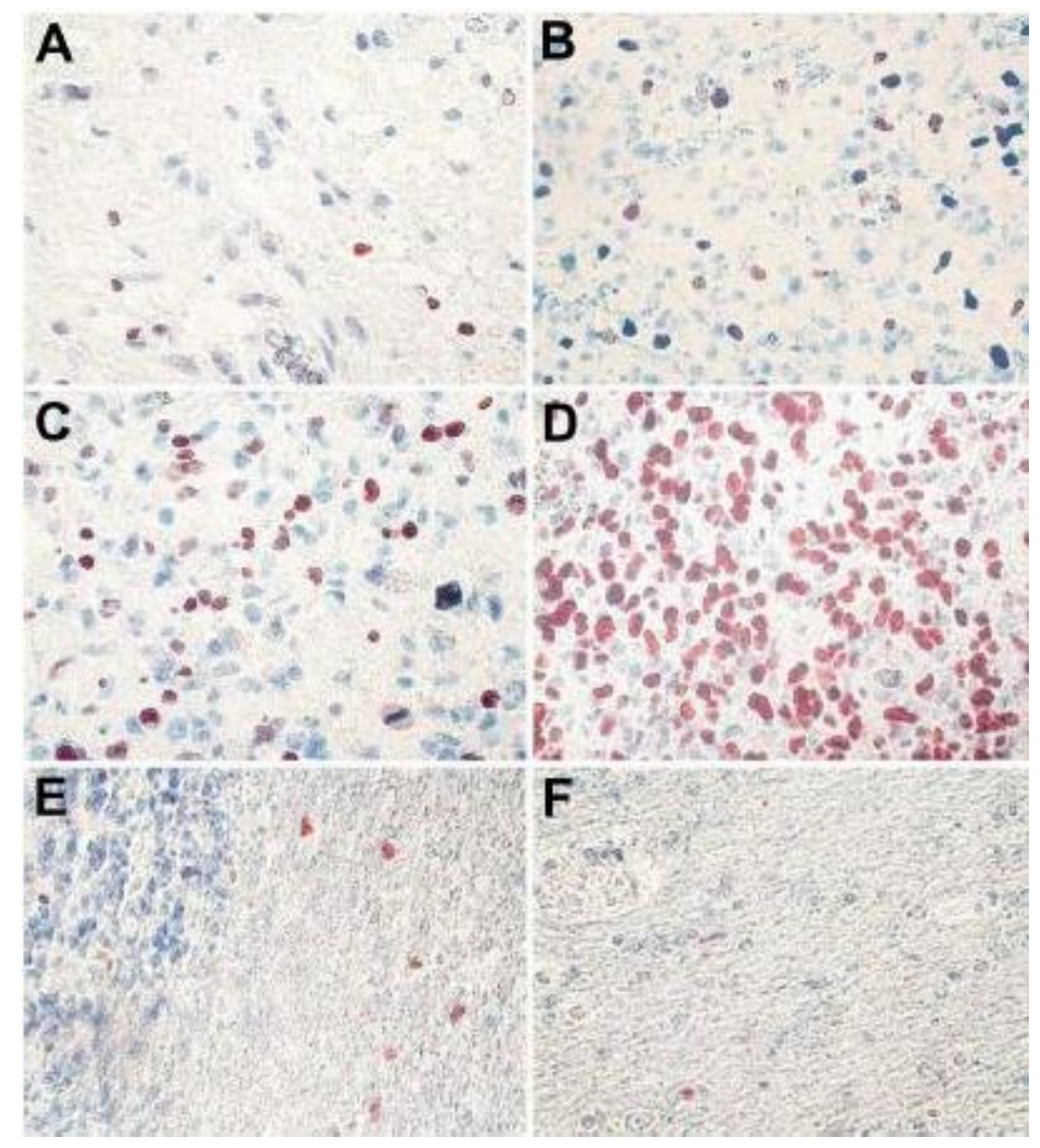

Abbildung 4: Immunhistochemische Detektion der MCM3-Expression in Astrozytomen und normalem Hirngewebe. Es zeigt sich eine größere MCM3Expression (intensivere Braunfärbung) von Glioblastomen im Vergleich zu normalem Hirngewebe. A) Astrozytom WHO-Grad I, B) Astrozytom WHO-Grad III, C) anaplastisches Astrozytom, D) Glioblastoma multiforme, E) normales Kleinhirngewebe, F) normales Großhirngewebe. Modifiziert nach Soeling et al. 2005, S.253. 

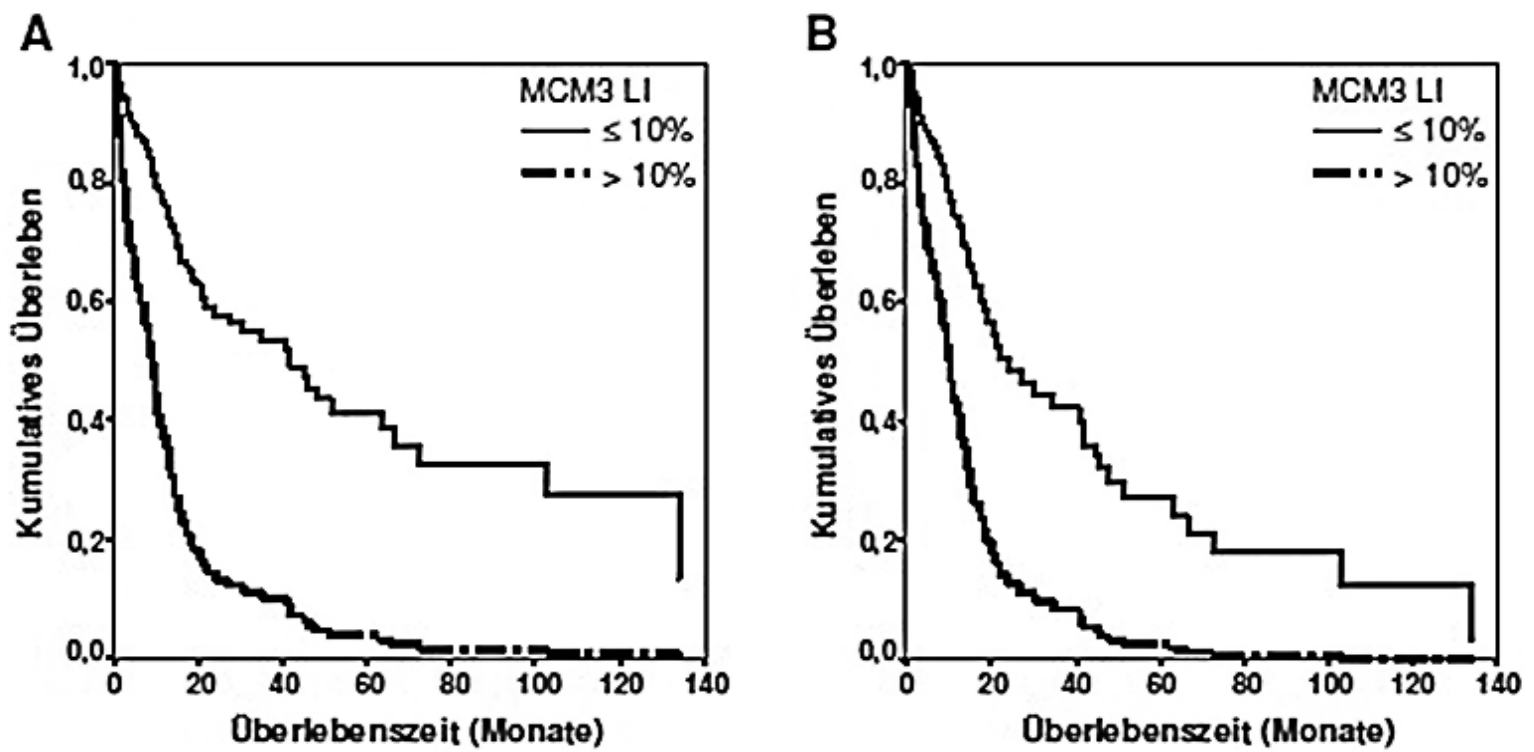

Abbildung 5: Überleben von Patienten mit Astrozytomen Grad II-IV in Bezug auf die intratumorale MCM3-Expression. A) Univariante, B) Multivariante unter Einbeziehung von Geschlecht, Alter und histologischer Differenzierungsgrad. $\mathrm{LI}=$ labeling index entspricht dem Prozentsatz MCM3-positiver Zellen. Patienten mit einem $\mathrm{LI}<10 \%$ überleben signifikant länger. Modifiziert nach Soeling et al. 2005, S.254.

In Glioblastomzellen ist MCM3 im Vergleich zu normalem Hirngewebe ebenfalls vermehrt exprimiert (Abbildung 4). Für MCM7 in Glioblastomen konnte bereits gezeigt werden, dass MCM7 keinen Marker für die Einschätzung der Überlebenszeit darstellt, sehr wohl aber einen Aussagewert für die zu erwartende Proliferation und Radiosensitivität des Tumors haben könnte (Facoetti et al. 2006).

Nicht geklärt ist bislang, welche Effekte eine Suppression von MCM3 in Glioblastomen haben könnte. Da die MCM3-Proteine entscheidend am Zellzyklus beteiligt sind, könnte eine Suppression von MCM3 deutliche Auswirkungen auf den Tumor und sein Wachstum haben. 


\subsection{Fragestellung}

Das Ziel meiner Arbeit war zu prüfen, welche Rolle die MCM3-Proteine bei Glioblastomen spielen und ob MCM3 ein mögliches therapeutisches Angriffsziel darstellt. Da MCM3 bei Glioblastomen im Vergleich zu normalem Hirngewebe vermehrt exprimiert wird, sollte zunächst mittels Western Blot untersucht werden, ob eine spezifische Suppression von MCM3-Proteinen durch RNA-Interferenz in humanen Glioblastomzellen in vitro möglich ist. Dazu wurden humane Glioblastomzellen (U87MG) untersucht.

Da MCM3 eine entscheidende Rolle bei der Zellteilung im Zellzyklus spielt, sollte weiterhin geprüft werden, welche Auswirkungen eine gezielte Suppression von MCM3 auf Zellvitalität, Zellproliferation, Zellzyklus und Zelltod hat. Eine mögliche Induktion von Apoptose oder verminderte Proliferation der Glioblastomzellen infolge von MCM3Suppression könnte einen neuen Therapieansatz liefern. 


\section{Materialien und Methoden}

\subsection{Material}

\subsubsection{Zelllinie und Medien}

Eingesetzte Zelllinie

Zellart

Eingesetztes Medium

\subsubsection{Substanzen}

APS $10 \%$

Acrylamid/ bis-acrylamide $30 \%$

Agarose

BSA

Chloroform

Dc Protein Assay Reagent A, B und S

Dulbecco's modified Eagle's medium

Dimethylsulfoxid

FACSflow

fötales Kälberserum

GeneRuler 100 bp DNA Ladder

Glycerin

Glycin

Isopropanol

iQ SYBR Green Supermix

Laemmli Sample Buffer (4x)

Lipofectamine RNAiMAX

Lumi-Light Western Blotting Substrate

Methanol

Natriumcitrat

Non-Fat Dry Milk (1\%)

Opti-MEM GIBCO

PBS
U87MG

Humane Glioblastomzellen

Dulbecco's modified Eagle's medium mit $10 \%$ fötalem Kälberserum

BioRad, München

Roth, Karlsruhe

Boehringer, Heidelberg

Serva, Heidelberg

Roth, Karlsruhe

BioRad, München

Biochrom AG, Berlin

BioRad, München

BD Biosciences, San Jose, USA

Biochrom AG, Berlin

Fermentas, St. Leon-Rot

Merck, Darmstadt

Applichem, Darmstadt

Roth, Karlsruhe

BioRad, München

BioRad, München

Invitrogen, Darmstadt

Roche Applied Science, Mannheim

Roth, Karlsruhe

SIGMA Aldrich, Steinheim

TSI, Zeven

Invitrogen, Darmstadt

LONZA, Verviers, Belgien 
Ponceau-S-Lösung

Propidiumiodid

Proteinaseinhibitor-Cocktail-Tabletten

(Complete Mini)

RNase-Free DNase Set

RNaseOUT

Roti-Mark Prestained - Protein Marker

Salzsäure

Schwefelsäure

SDS

SuperScript II Reverse Transcriptase

Thiazolylblau Tetrazoliumbromid (MTT)

TEMED

TriFast

Tris

Triton X-100

Trypan-Blau

Trypsin

Tween20
Applichem, Darmstadt

Roth, Karlsruhe

Roche Applied Science,

Mannheim

Qiagen, Hilden

Invitrogen, Darmstadt

Roth, Karlsruhe

Roth, Karlsruhe

Roth, Karlsruhe

SIGMA Aldrich, Steinheim

Invitrogen, Darmstadt

Fluka, Buchs, Schweiz

Roth, Karlsruhe

peqGOLD, Erlangen

Applichem, Darmstadt

Calbiochem, Schwalbach

SIGMA Aldrich, Steinheim

Roth, Karlsruhe

Calbiochem, Schwalbach

\subsubsection{Lösungen und Puffer}

Transferpuffer Tris $25 \mathrm{mM}$, Glycin $192 \mathrm{mM}, 0.01 \%$ SDS, $15 \%$ Methanol

Blotto $1 \%$ 1x TBS, $1 \%$ Milchpulfer, 0,1\% Tween20, 0,01\% Thimerosal

Ripa-Lysispuffer $\quad 300 \mu \mathrm{l}$ Ripa, $30 \mu \mathrm{l}$ Proteinaseinhibitor, $270 \mu \mathrm{l} \mathrm{H}_{2} \mathrm{O}$

Nicoletti-Puffer $\quad 0,1 \%$ Natriumcitrat, $0,1 \%$ Triton X-100, $5 \mu \mathrm{g}$ Propidiumiodid $/ 1 \mathrm{ml}$ Puffer

\subsubsection{Verbrauchsmaterialen}

6-Well-Flachbodenkulturplatten

96-Well-Flachbodenkulturplatten

BioPhotometer Küvetten
TPP, Trasadingen, Schweiz

BD Biosciences, San Jose, USA

Eppendorf AG, Hamburg 
Combitips plus ( $1 \mathrm{ml}, 5 \mathrm{ml}$ )

FACS Rundbodenröhrchen ( $5 \mathrm{ml}$ )

Filterpapier

Gewebekulturflaschen (T25, T75)

Immobilion-P (PVDF; 0,45 $\mu \mathrm{M}$ )

Pipetten ( $5 \mathrm{ml}, 10 \mathrm{ml}, 25 \mathrm{ml}$ )

Reagiergefäß $(0,5 \mathrm{ml}, 1,5 \mathrm{ml}, 2 \mathrm{ml})$

Zellschaber

Zentrifugenröhrchen (15 ml, $50 \mathrm{ml}$ )

\subsubsection{Geräte}

BioPhotometer

Dual Gel Caster

FACScan

Gelelektrophoresekammern

Hämozytometer

(Neubauer, Tiefe 0,1 mm, 0,0025 mm²)

iCycler MyiQ single color Real-Time PCR

Kamera Leica DC 300 FX

Labmate-Pipetten

LAS-4000 Mini (Luminescent Image

Analyzer)

Lichtmikroskop Leica DM IRB

Lichtmikroskop

Mikrotiterplatten-Lesegerät (SUNRISE)

Mikrotiterplatten-Lesegerät (Wallac Victor 2)

Multipette plus

NanoDrop ND-1000 Spectrophotometer

Pipettierhilfe

Schüttelgerät Promax 1020

Semi-Dry-Blot-Apparatur

Sterilbank SterilGARD III advance

Zellkulturinkubator

Zentrifugen
Eppendorf AG, Hamburg

BD Biosciences, San Jose, USA

Schleicher und Schüll, Dassel

TPP, Trasadingen, Schweiz

Millipore, Schwalbach

TPP, Trasadingen, Schweiz

Sarstedt, Nümbrecht

TPP, Trasadingen, Schweiz

Greiner Bio-One, Frickenhausen

Eppendorf AG, Hamburg

Hoefer, Holliston, USA

Becton \& Dickinson

Hoefer, Holliston, USA

Brand, Wertheim

Eppendorf AG, Hamburg

BioRad, München

Leica Microsystems, Cambridge, UK

Abimed, Langenfeld

FujiFilm (LifeScience), Düsseldorf

Leica Microsystems, Wetzlar

Zeiss, Jena

Tecan, Crailsheim

Perkin Elmer, Rodgau

Eppendorf AG, Hamburg

Thermo Fisher Scientific, Epsom, UK

Gilson, Middleton, USA

Heidolph, Schwabach

Hoefer, Holliston, USA

Baker, Sanford, USA

Heraeus Instruments, Hanau

Eppendorf AG, Hamburg 


\subsubsection{Kommerzielle Kits}

RNeasy Mini Kit

Cell Death Detection ELISAplus

„Cell Proliferation Elisa“ BrdU (colorimetric) Roche Applied Science, Mannheim

\subsubsection{Antikörper}

\section{Primär-Antikörper}

MCM3-Antiserum:

Firma Boehringer, Wirt Kaninchen, polyklonaler Antikörper, eingesetzte Kon-zentration $1: 4.000$

\section{a-Tubulin-Antikörper:}

Firma Dianova, Wirt Maus, monoklonaler Antikörper, eingesetzte Konzentration $1: 1.000$

Cleaved Caspase-3-Antikörper:

Firma Cell Signaling, Wirt Kaninchen, polyklonaler Antikörper, eingesetzte Konzentration 1:1.000

\section{Sekundär-Antikörper}

Anti-Rabbit-(HRP-linked lgG) Antikörper:

Firma BD Biosciences, Wirt Ziege, eingesetzte Konzentration 1:1.000

Donkey-Anti-Mouse-(lgG) Antikörper:

Firma Dianova, Wirt Esel, eingesetzte Konzentration 1:10.000 


\subsubsection{MCM3-siRNAs}

\begin{tabular}{|l|l|l|c|}
\hline \multicolumn{1}{|c|}{ siRNA } & \multicolumn{1}{c|}{ Firma } & \multicolumn{1}{c|}{ Target Sequenz } & $\begin{array}{c}\text { Eingesetzte } \\
\text { Konzentration }\end{array}$ \\
\hline $\begin{array}{l}\text { Kontroll- } \\
\text { siRNA }\end{array}$ & $\begin{array}{l}\text { Dharmacon, } \\
\text { Lafayette, USA }\end{array}$ & NON TARGETING siRNA & $20 \mathrm{nM}$ \\
\hline siRNA 10 & $\begin{array}{l}\text { Dharmacon, } \\
\text { Lafayette, USA }\end{array}$ & CUGAUUGCCUGUAAUGUUA & $20 \mathrm{nM}$ \\
\hline siRNA 13 & $\begin{array}{l}\text { Dharmacon, } \\
\text { Lafayette, USA }\end{array}$ & CUAACCGGCUUCUGAACAA & $10 \mathrm{nM}$ \\
\hline siRNA 15 & $\begin{array}{l}\text { Dharmacon, } \\
\text { Lafayette, USA }\end{array}$ & AGUCUCAGCUUCUGCGGUA & $20 \mathrm{nM}$ \\
\hline siRNA 16 & $\begin{array}{l}\text { Dharmacon, } \\
\text { Lafayette, USA }\end{array}$ & GUACCGUGGUGCUGGACGA & $20 \mathrm{nM}$ \\
\hline siRNA 3'UT & $\begin{array}{l}\text { Dharmacon, } \\
\text { Lafayette, USA }\end{array}$ & CAGUUAAGGUGAAUAUGUA & $20 \mathrm{nM}$ \\
\hline
\end{tabular}

Tabelle 5: Eingesetzte siRNAs. Aufgeführt sind Name, Firma, Target Sequenz und die eingesetzte Konzentration. Alle siRNAs sind On-Target-Plus modifiziert und high performance liquid chromatography (HPLC)-gereinigt.

\subsubsection{Primer für real-time RT-PCR}

\begin{tabular}{|l|l|l|}
\hline \multicolumn{1}{|c|}{ Primer } & \multicolumn{1}{|c|}{ Firma } & \multicolumn{1}{c|}{ Sequenz } \\
\hline GAPDH Human Sense & Biomers GmbH, Ulm & 5'-agg gct gct ttt aac tct gg-3' \\
\hline GAPDH Human Antisense & Biomers GmbH, Ulm & 5'-gat ctc gct cct gga aga tg-3' \\
\hline MCM3 Human Sense & Biomers GmbH, Ulm & 5'-tca agc ctg tcc tga cac ag-3' \\
\hline MCM3 Human Antisense & Biomers GmbH, Ulm & 5'-cag gtc cac agt ctt gct ca-3' \\
\hline
\end{tabular}

Tabelle 6: Eingesetzte Primer. Aufgeführt sind Name, Firma und Sequenz. 


\subsection{Methoden}

\subsubsection{Zellen auftauen}

Die Zellen wurden bei $37^{\circ} \mathrm{C}$ im Wasserbad aufgetaut, zentrifugiert (1.200 rpm für 5 Minuten bei $4{ }^{\circ} \mathrm{C}$ ), der Überstand wurde verworfen. Das Zellpellet wurde in $8 \mathrm{ml}$ DMEM mit 10 \% FCS aufgenommen, in 25T-Fläschchen überführt und die Zellen vorsichtig vereinzelt.

\subsubsection{Zellen einfrieren}

Die Zellen wurden in $10 \%$ Dimethylsulfoxid (DMSO), 10 \% FCS, $80 \%$ Roswell Park Memorial Institute Medium (RPMI-Medium) zunächst für 16 Stunden bis 24 Stunden von Raumtemperatur auf $-80{ }^{\circ} \mathrm{C}$ abgekühlt und dann in flüssigem Stickstoff bei $-198^{\circ} \mathrm{C}$ eingefroren.

\subsubsection{Zellen passagieren}

Die Zellen wurden durch Trypsinierung passagiert. Zum Ablösen wurde $1 \mathrm{ml}$ Trypsin auf die Zellen gegeben, das nach ein bis zwei Minuten bis auf wenige Mikroliter abgesaugt wurde. Dann wurde die Kulturflasche für 5 - 10 Minuten in den Inkubator gestellt. Die gelösten U87MG-Zellen wurden danach in DMEM aufgenommen, im gewünschten Verhältnis geteilt und mit frischem DMEM mit 10 \% FCS wieder plattiert.

\subsubsection{Zellkultur}

Die adhärent in Einzelschicht wachsenden U87MG-Gliomblastomzellen wurden in Dulbecco's modified Eagle's medium (DMEM) $+10 \%$ fötalem Kälberserum (FCS) Medium in Gewebekulturflaschen in gesättigter Wasserdampfatmosphäre $\left(5 \% \mathrm{CO}_{2}\right.$, $95 \%$ Luftfeuchtigkeit) bei $37^{\circ} \mathrm{C}$ kultiviert. Die Zellen wurden zweimal pro Woche unter sterilen Bedingungen passagiert und in frischem Kulturmedium in entsprechender Verdünnung wieder ausgesät.

Das verbrauchte Medium wurde dazu aus der Gewebekulturflasche mit einer Pasteurpipette abgesaugt und die Zellen vorsichtig mit phosphate buffered salinePuffer (PBS) gewaschen. Anschließend wurden die Zellen durch Trypsineinwirkung ( 1 - 2 Minuten bei $37^{\circ} \mathrm{C}$ ) vom Flaschenboden gelöst. Durch die Zugabe von DMEM wurde das Trypsin wieder inaktiviert und die Zellen vorsichtig komplett abgelöst und 
vereinzelt. Je nach vorherrschender Zelldichte und Versuchsvorhaben wurde ein bestimmter Anteil der Zellen (1:3 bis 1:5) wieder neu ausgesät.

\subsubsection{Zellen ernten und Herstellung von Zelllysaten}

Zunächst wurde der Radioimmunoprezipitationsassay-Puffer (RIPA-Puffer) hergestellt und die Zellkulturflasche auf Eis gestellt. Nach dem Absaugen des Kulturmediums wurden die Zellen zweimal mit PBS gewaschen und mittels RIPA-Puffer auf Eis lysiert. Danach wurden die Zellen über 20 Minuten auf Eis inkubiert und mit einem Vortexer vorsichtig gemischt. Im folgenden Schritt wurden die Zelllysate für fünf Minuten bei $4{ }^{\circ} \mathrm{C}$ und $13.000 \mathrm{rpm}$ zentrifugiert. Nach Abnehmen und Überführen des Überstandes in bereits vorgekühlte Eppendorf-Röhrchen, wurden diese bei $-80{ }^{\circ} \mathrm{C}$ eingefroren. Zuvor wurde von jeder Probe noch ein Aliquot (1:10 Verdünnung) für die Proteinbestimmung mittels Lowry-Test abgenommen.

\subsubsection{Zellzählung mittels Neubauer-Zählkammer}

Die Neubauer-Zählkammer besteht aus vier großen Quadraten, welche wiederum jeweils 16 kleine Quadrate enthalten, die unter dem Lichtmikroskop ausgezählt werden können. Aus der Summe der Zellen kann die Zellzahl pro $\mathrm{ml}$ mit folgender Formel berechnet werden:

Zellzahl aus Großquadraten $* 2,5 * 1000=$ Zellzahl pro Milliliter

Da die Zellen für die einzelnen Versuche jeweils in einer bestimmten Zellzahl ausgesät werden mussten, wurde vor jedem Aussäen die genaue Zellzahl ermittelt. Dazu wurden nach gutem Durchmischen der Zellsuspension, die bei der Passagierung gewonnen wurde, die Zellen gezählt und ein entsprechender Ansatz mit frischem Medium hergestellt, der dann ausplattiert werden konnte.

\subsubsection{Transfektion}

Das Einbringen von DNA, RNA oder Oligonukleotiden in eukaryotische, lebende Zellen wird als Transfektion bezeichnet. Damit kann erreicht werden, dass z.B. mittels siRNA die Expression eines Zielproteins inhibiert wird. 
Für das Einbringen von Nukleinsäuren in Zellen müssen aufgrund der Polarität der Nukleinsäuren Trägersubstanzen benutzt werden. Ohne die Trägersubstanz können die Nukleinsäuren die Zellmembran kaum überwinden.

Deshalb werden sie notwendigerweise, um einen effektiven Transfer in die Zielzelle zu erzielen, an Trägersubstanzen angehängt. Eine häufig verwendete Methode ist die Koppelung an kationische Lipide, die über elektrostatische Wechselwirkungen die Polarität der DNA oder RNA verringern, so dass der Transport der negativ geladenen Teilchen durch die negativ geladene Zellmembran erleichtert wird (Thierry et al. 1997). In Wasser bilden Lipide vesikuläre Strukturen aus, die als Liposomen bezeichnet werden. Die Liposomen werden direkt in die Zelle aufgenommen und geben nach Überwindung der Zellmembran ihre Ladung ins Zellinnere ab. Damit ist der Transfer abgeschlossen. Inzwischen wurden verschiedene Lipidgemische zur Transfektion entwickelt.

In dieser Arbeit wurde ein häufig mit eukaryotischen Zelllinien verwendetes Transfektionsreagenz, das Lipofectamine RNAiMAX, für die Transfektion verwendet.

Bei der Plattierung der U87MG-Zellen für die Versuche wurden immer $1 \times 10^{5}$ Zellen in $2 \mathrm{ml}$ Medium mit $10 \%$ FCS in 6-Loch-Mikrotiterplatten plattiert. Die Transfektion wurde immer 22 Stunden nach der Plattierung der Zellen durchgeführt. Für die Transfektion wurden, aufgrund der geringen Eigentoxizität und der speziellen Optimierung für siRNA Versuche, Liposomen vom Typ Lipofecatmine RNAiMAX benutzt.

Nachdem im Western Blot (siehe 2.2.10) die siRNA-Konzentration mit der höchsten Protein-Suppression ermittelt wurde, wurden bei allen Versuchen diese ermittelten Konzentrationen eingesetzt. Für die MCM3-siRNA 13 betrug diese $10 \mathrm{nM}$ und für MCM3-siRNA 15 war diese $20 \mathrm{nM}$. Die Kontroll-siRNA wurde ebenfalls in einer Konzentration von $20 \mathrm{nM}$ eingesetzt. Bei der Herstellung der Transfektionsansätze wurde zunächst für jeden Ansatz ein $200 \mu \mathrm{l}$ siRNA/Optimem-Mix mit der entsprechenden siRNA-Konzentration hergestellt und fünf Minuten bei Raumtemperatur inkubiert.

Gleichzeitig wurde je siRNA-Ansatz ein $200 \mu \mathrm{l}$ RNAiMAX/Optimem-Mix mit 7,5 $\mu \mathrm{l}$ RNAiMAX pro Ansatz angesetzt. Danach wurde zu jedem siRNA/Optimem-Mix $200 \mu \mathrm{l}$ des RNAiMAX/Optimem-Mixes hinzugefügt, so dass sich ein Gesamtvolumen von $400 \mu$ ergab. Diese Mixe wurden dann vorsichtig vermischt. Um das Volumen in den 
Wells konstant auf $2 \mathrm{ml}$ einzustellen, wurde vor der Zugabe dieser Mischansätze in die zu transfizierenden Wells der U87MG-Zellen jeweils $400 \mu \mathrm{l}$ altes Medium je Well abgenommen. Die Zellen wurden dann 48 Stunden nach Transfektion für die weiteren Versuche verwendet.

\subsubsection{RNA-Interferenz}

Die RNA-Interferenz (RNAi) ist ein natürlicher, evolutionärer Mechanismus zur ProteinSuppression bei eukaryotischen Zellen, der auf dem Abbau von mRNA beruht. Die mRNA wird dabei in Bruchstücke gespalten, so dass diese nicht mehr verwendet werden kann und die codierte Information zerstört wird.

Die ersten Arbeiten zur RNA-Interferenz wurden bereits Mitte der achtziger Jahre durchgeführt. Izant veröffentlichte 1984 einen Versuch, bei dem er ein DNA-Konstrukt in Zellen eines Gewebes eingeschleuste. Dieses DNA-Konstrukt kodierte für Antisense-RNA, die komplementär zur mRNA der Thymidinkinase war. Er beobachtete dabei, dass es zu einer deutlichen Reduktion der Thymidinkinase in diesen Zellen kam (Izant und Weintraub 1984).

Fire und Mello zeigten dieses ebenfalls für den Fadenwurm Caenorhabditis elegans (Fire et al. 1991, Fire et al. 1998). Im Verlauf wurde dies für zahlreiche Eukaryoten und auch bei humanen Zellen gezeigt.

Aus der Vielzahl von Publikationen zu dem Thema wurde ein Modell zur Funktionsweise von RNA-Interferenz entwickelt (Chapman und Carrington 2007, Zamore et al. 2000). Die Hauptelemente der RNA-Interferenz bestehen aus drei Schritten.

Zunächst wird dsRNA in kleinere Fragmente (19 bis 23 Basenpaare) zerteilt. Die Fragmente dieser Spaltung werden als short interfering RNA (siRNA) bezeichnet. Im zweiten Schritt spielt der RNA-induced silencing complex (RISC), ein Komplex aus RNA und Proteinen, eine wichtige Rolle. Der RNA-Anteil besteht aus einer small interfering RNA (siRNA) und der Proteinanteil besteht aus Proteinen der ArgonautFamilie (Hutvagner und Simard 2008). Zunächst werden die einzelnen Doppelstrangmoleküle in Einzelstrangmoleküle gespalten und der Einzelstrang, der komplementär zur abzubauenden mRNA (guide-Strang) ist, integriert. Dadurch wird der RISCKomplex aktiviert. Die siRNA dient so als Schablone, die dem RISC Komplex den Weg zur komplementären mRNA im Zytosol weist (Bernstein et al. 2001). 
Beim letzten Schritt sucht der mit dem Einzelstrang beladene RISC-Komplex nach einer komplementären mRNA. Wenn diese gefunden wurde, spaltet eine im RISCKomplex enthaltene Endonuklease die entsprechende mRNA (Hutvagner und Zamore 2002). Der übriggebliebene Strang (passenger-Strang) wird durch Spaltung ebenfalls zerstört.

Zusammenfassend kann man sagen, dass die kurzen RNA-Sequenzen die Spezifität bestimmen und die Argonaut-Proteine, die im RISC-Komplex enthalten sind, für die Degradierung der mRNA zuständig sind (Abbildung 6). Das Prinzip der siRNAInterferenz kann dazu benutzt werden, um die Proteinsynthese herunter zu regulieren oder im Extremfall komplett auszuschalten (Chapman und Carrington 2007, Hammond et al. 2000). Für diese Entdeckung erhielten Fire und Mello 2006 den Nobelpreis. 


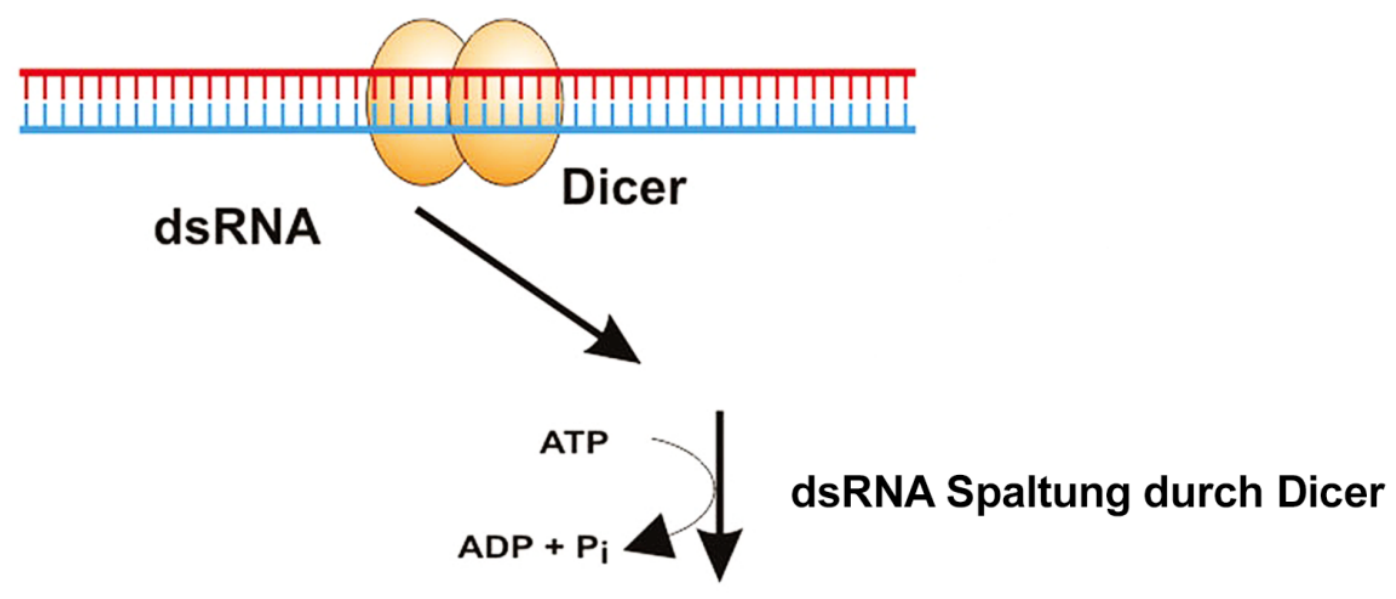

SIRNA
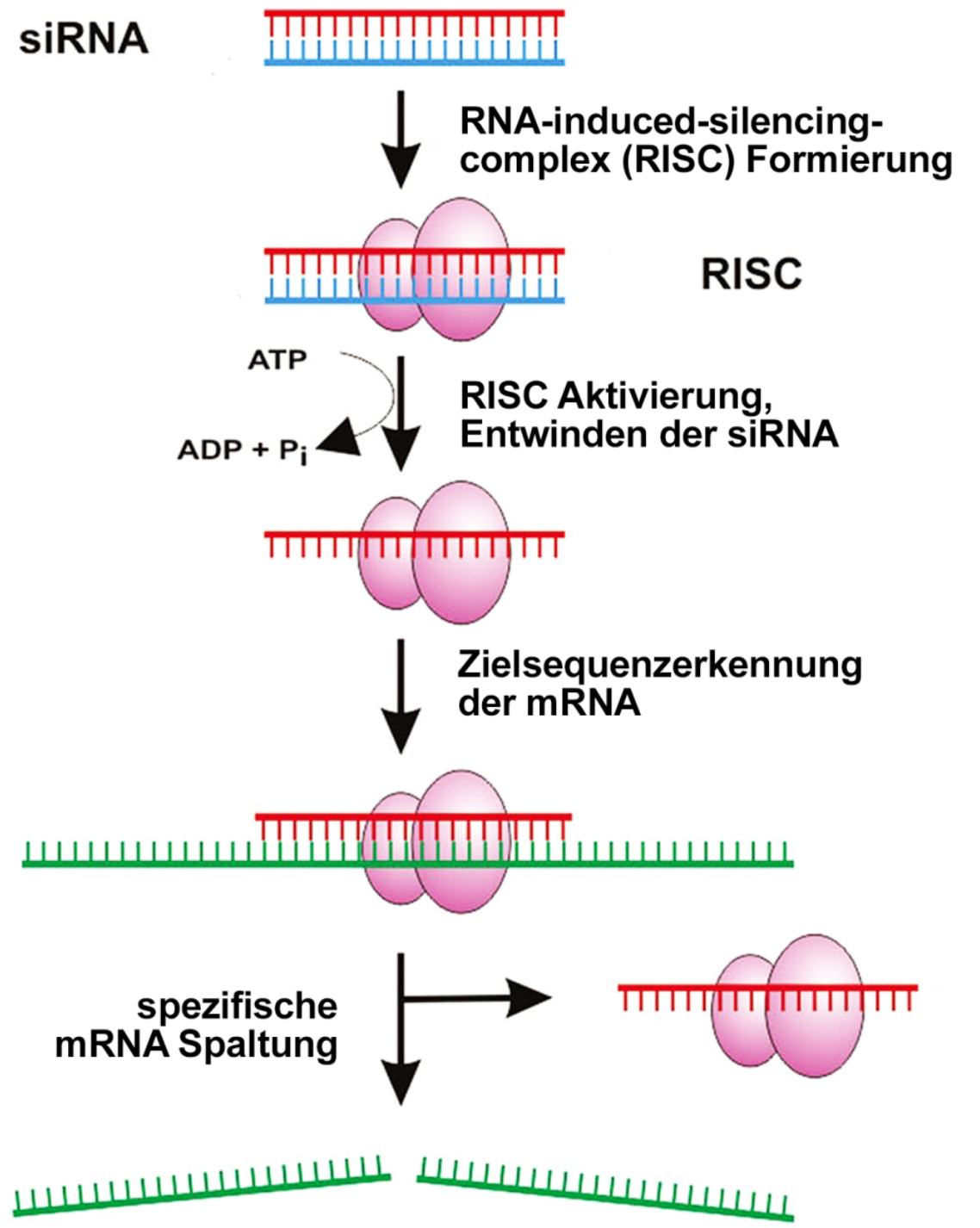

Abbildung 6: Mechanismus der RNA-Interferenz durch short-interfering-RNAs (siRNA). Modifiziert nach Rutz und Scheffold 2004, S.79. 


\subsubsection{Proteinbestimmung mittels Lowry-Assay}

Um gleiche Mengen Protein der Zelllysate in der Western Blot-Analyse einsetzen zu können, wurde eine Proteingehaltsbestimmung der Zelllysate mit einem Lowry-Assay durchgeführt. Bei diesem ist die Bestimmung der Proteinkonzentration durch einen Farbumschlag und die anschließende Messung der Absorption möglich.

Die Methode zur Quantifizierung nach Lowry (Lowry et al. 1951) beruht auf zwei aufeinanderfolgenden Reaktionen. Die erste ist die Reduktion von $\mathrm{Cu}^{2+} \mathrm{zu} \mathrm{Cu}^{+}$in Anwesenheit von Proteinen unter alkalischen Bedingungen. Das entstandene $\mathrm{Cu}^{+}$ führt dann zur Bildung eines blauen Farbstoffs bei Umsetzung mit dem Folin-Reagenz. Die gemessene Absorption bei einer Wellenlänge von $750 \mathrm{~nm}$ und die Proteinkonzentration stehen in einem proportionalen Verhältnis zueinander, wodurch eine genaue Errechnung der Proteinkonzentration möglich ist. Als Proteinstandard wurde eine Verdünnungsreihe mit fünf Verdünnungen der Standardproben in folgenden Konzentrationen hergestellt: $0,25 \mu \mathrm{g} / \mu \mathrm{l}, 0,5 \mu \mathrm{g} / \mu \mathrm{l}, 0,75 \mu \mathrm{g} / \mu \mathrm{l}, 1 \mu \mathrm{g} / \mu \mathrm{l}$ und $1,25 \mu \mathrm{g} / \mu \mathrm{l}$.

Zuerst wurden je $5 \mu \mathrm{l}$ der Standardproben, mit bekannter Konzentration, sowie $5 \mu \mathrm{l}$ Ripa-Puffer als Negativkontrolle in Triplikaten in eine 96-Well-Flachbodenkulturplatte pipettiert. Die Zelllysate wurden direkt nach der Erstellung im Verhältnis 1:10 mit Wasser verdünnt und wurden dann in Duplikaten (je $5 \mu \mathrm{l}$ ) auf die gleiche Platte gegeben. Dann erfolgte die Zugabe von $25 \mu$ pro Well des Reagenzes A. Im Anschluss wurden je Well zudem $200 \mu \mathrm{l}$ des Reagenzes B hinzugefügt und 15 Minuten bei Raumtemperatur inkubiert.

Am Ende der Inkubationszeit wurde die Absorption der Standards und der Lysatproben in einem Mikrotiterplatten-Lesegerät gemessen und die Absorption der Negativkontrolle (Ripa-Puffer) von den Messwerten abgezogen. Da die Probenkonzentration der Standardreihe bekannt ist, kann die Konzentration der unbekannten Proben anhand einer Standardkurve, die mit Hilfe der Standardreihe erstellt wurde, rechnerisch bestimmt werden. Die Auswertung erfolgte mittels Microsoft Excel.

\subsubsection{Western Blot}

Eine Western Blot-Analyse umfasst die Schritte Polyacrylamid-Gelelektrophorese (SDS-PAGE), Proteintransfer auf eine Membran sowie die Immundetektion. 
Mittels der Gelelektrophorese wird das aufgetragene Proteingemisch im Trenngel entsprechend seinem Molekulargewicht durch ein senkrecht zum Polyacrylamid-Gel gerichtetes elektrisches Feld aufgetrennt. Nachdem die Proteine anhand ihres Gewichtes aufgetrennt wurden, folgt der Transfer auf eine Polyvinyldifluorid (PVDF)Membran. Dieses erfolgt ebenfalls mit Hilfe eines elektrischen Feldes, durch das die Proteine aus dem Gel auf die PVDF-Membran transferiert werden. Nach dem Transfer werden die unspezifischen Bindungsstellen durch Inkubation mit einem Blockpuffer, der fettfreies Milchpulver enthält, blockiert, so dass eine unspezifische Bindung der Antikörper verhindert wird. Als nächster Schritt erfolgt die Inkubation mit Antikörpern. Der erste Antikörper bindet an sein entsprechendes Zielprotein. Der zweite Antikörper wiederum ist gegen die konstante Region des ersten Antikörpers gerichtet und bindet dort. Er stammt immer aus einer anderen Spezies und ist an ein Enzym gekoppelt, das durch die Zugabe eines Chemilumineszenz-Substrates, die Bildung eines lichtemittierenden Produktes katalysiert. Diese Lichtemission kann dann über ein Messgerät (Image Reader) quantifiziert werden.

Die für die Beurteilung des Ergebnisses wichtige Normierung auf jeweils gleiche Mengen eingesetztes Protein, wird über die Detektion eines konstant exprimierten Proteins (housekeeping gene) erreicht. In dieser Arbeit wurde a-Tubulin als housekeeping gene eingesetzt.

Zur Durchführung der SDS-Gelelektrophorese wurden jeweils ein Trenngel $(7,5 \%)$ und ein Sammelgel $(3,5 \%)$ gegossen. Das Gel wurde nach der Polymerisation in eine Gelkammer, die mit 1x Laufpuffer gefültt war, eingespannt. Es wurden immer $20 \mu \mathrm{g}$ Protein in $10 \mu$ geladen.

Um gleiche Mengen Protein der Gesamtzellextrakte in gleichem Volumen zu erhalten, wurde die hergestellte Proteinlösung entsprechend der Proteinbestimmung nach Lowry mit $\mathrm{H}_{2} \mathrm{O}$ verdünnt. Die festgelegte Standardproteinmenge (20 $\mu \mathrm{g}$ Protein) wurde in einem festgelegten Standardvolumen (7,5 $\mu \mathrm{l}$ ) hergestellt und anschließend mit 2,5 $\mu \mathrm{l}$ $4 \times$ Lämmli Puffer versetzt, so dass sich ein Gesamtvolumen zur Beladung der Geltaschen von $10 \mu$ l ergab (Tabelle 7).

Danach wurden die Proben für fünf Minuten auf $100^{\circ} \mathrm{C}$ erwärmt, für zwei Minuten auf Eis gelagert und dann zentrifugiert. Im Anschluss wurden die Proben mittels einer Hamilton-Spritze aufgetragen, wobei in der ersten Bahn zur Überprüfung der Molekulargewichte immer der Roti@-Mark prestained Marker geladen wurde. 


\begin{tabular}{|c|c|c|c|c|c|}
\hline $\begin{array}{c}\text { siRNA Probe / } \\
\text { eingesetzte Konzentration }\end{array}$ & $\begin{array}{c}\text { Protein- } \\
\text { konzentration } \\
(\mu \mathrm{g} / \mu \mathrm{l})\end{array}$ & $\begin{array}{l}\text { Mittelwert Protein- } \\
\text { konzentration } \\
(\mu \mathrm{g} / \mu \mathrm{l})\end{array}$ & $\begin{array}{l}20 \mu \mathrm{g} \text { Protein } \\
\text { entspricht } x \mu \mathrm{l}\end{array}$ & $\begin{array}{c}\mathrm{H}_{2} \mathrm{O} \text { ad } 7,5 \mu \mathrm{l} \\
\quad \text { zur } \\
\text { Proteinprobe }\end{array}$ & $\begin{array}{l}\text { ad } 2,5 \mu \mathrm{l} 4 \mathrm{x} \text { Lämmli-Puffer } \\
\text { ergibt } 10 \mu \mathrm{l} \text { Gesamtvolumen }\end{array}$ \\
\hline Kontroll-siRNA, $20 \mathrm{nM}$ & 6,17 & \multirow{2}{*}{5,73} & \multirow{2}{*}{3,49} & \multirow{2}{*}{4,01} & \multirow{2}{*}{2,50} \\
\hline Kontroll-siRNA, 20 nM & 5,28 & & & & \\
\hline MCM3-siRNA 10, $20 \mathrm{nM}$ & 6,77 & \multirow{2}{*}{6,87} & \multirow{2}{*}{2,91} & \multirow{2}{*}{4,59} & \multirow{2}{*}{2,50} \\
\hline MCM3-siRNA 10, $20 \mathrm{nM}$ & 6,97 & & & & \\
\hline MCM3-siRNA 13, $20 \mathrm{nM}$ & 4,17 & \multirow{2}{*}{4,28} & \multirow{2}{*}{4,67} & \multirow{2}{*}{2,83} & \multirow{2}{*}{2,50} \\
\hline MCM3-siRNA 13, $20 \mathrm{nM}$ & 4,39 & & & & \\
\hline MCM3-siRNA 15, $20 \mathrm{nM}$ & 4,79 & \multirow{2}{*}{4,92} & \multirow{2}{*}{4,07} & \multirow{2}{*}{3,43} & \multirow{2}{*}{2,50} \\
\hline MCM3-siRNA 15, $20 \mathrm{nM}$ & 5,05 & & & & \\
\hline MCM3-siRNA 16, $20 \mathrm{nM}$ & 6,44 & \multirow{2}{*}{6,43} & \multirow{2}{*}{3,11} & \multirow{2}{*}{4,39} & \multirow{2}{*}{2,50} \\
\hline MCM3-siRNA 16, 20 nM & 6,41 & & & & \\
\hline MCM3-siRNA 3'UT, 20 nM & 7,28 & \multirow{2}{*}{6,39} & \multirow{2}{*}{3,13} & \multirow{2}{*}{4,37} & \multirow{2}{*}{2,50} \\
\hline MCM3-siRNA 3'UT, 20 nM & 5,49 & & & & \\
\hline
\end{tabular}

Tabelle 7: Schema der Probenherstellung mit behandeltem U87MG-Zelllysat.

Die Elektrophorese erfolgte mit $40 \mathrm{~mA}$ für eine Stunde. Nachdem die Proben durch das Gel gelaufen waren, wurde der Transfer auf eine Membran mittels semi-dry-blot in "Sandwichform“ durchgeführt. Hierfür wurden drei Lagen Filterpapier, PVDFMembran, SDS-Gel und drei weitere Lagen Filterpapier auf der Anode luftblasenfrei aufeinander gelegt und anschließend die Deckplatte (Kathode) aufgesetzt. Alle einzelnen Bestandteile des Sandwiches wurden zuvor für 15 Minuten in Blottingpuffer äquilibriert. Der Transfer erfolgte für eine Stunde mit $0,8 \mathrm{~mA} / \mathrm{cm}^{2}$ Gelfläche. Zur Kontrolle der erfolgreichen Proteinübertragung aus dem Gel auf die PDVF-Membran erfolgte nach jedem Proteintransfer eine Ponceau-S-Färbung (Abbildung 7).

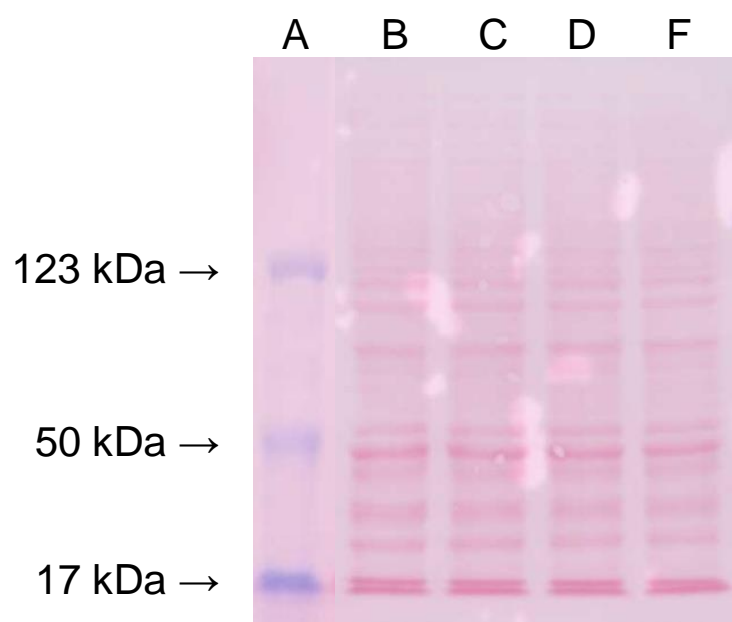

Abbildung 7: Ponceau-S-Färbung einer PDVFMembran. A) Roti@-Mark prestained Marker, B-F) aufgetragenes U87MG-Zelllysat mit jeweils $20 \mu \mathrm{g}$ Protein. Es zeigt sich eine gleiche Proteinverteilung in der Ponceau-S-Färbung. 
Im Anschluss wurde die Membran für eine Stunde in Blockpuffer gelegt und danach über Nacht (15 Stunden) mit dem ersten Antikörper bei $4{ }^{\circ} \mathrm{C}$ auf einem Schüttler inkubiert.

Am nächsten Morgen wurde die Membran dreimal mit Waschpuffer für je sieben Minuten gewaschen und anschließend für eine Stunde bei Raumtemperatur mit dem zweiten Antikörper inkubiert (Abbildung 8).

Danach wurde wiederum dreimal für je 15 Minuten mit Waschpuffer gewaschen. Die Detektion erfolgte mit frisch angesetztem Chemilumineszenz-Substrat (1:1) mit $0,125 \mathrm{ml} / \mathrm{cm}^{2}$ Membranfläche. Die Membran wurde für fünf Minuten inkubiert, in Kopierfolie eingeschlagen, im Anschluss mit dem LAS-4000 Mini belichtet und ausgewertet. Die Auswertung erfolgte mit dem Programm ImageJ.

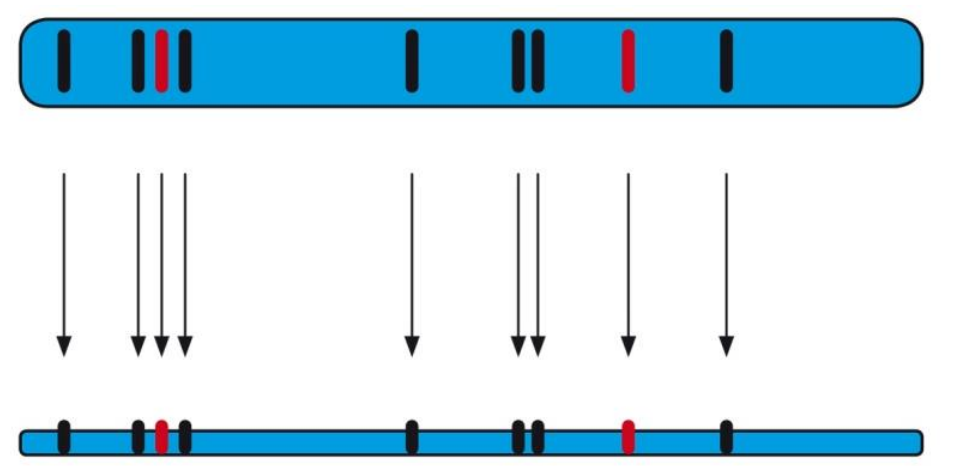

Gel

Transfer

PVDF-Membran

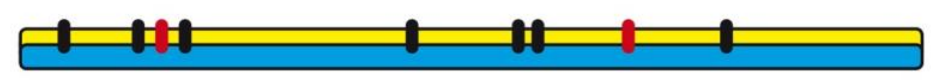

Blockierung der Membran

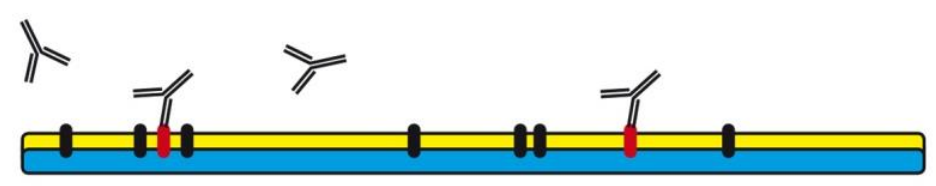

Inkubation mit Primärantikörper

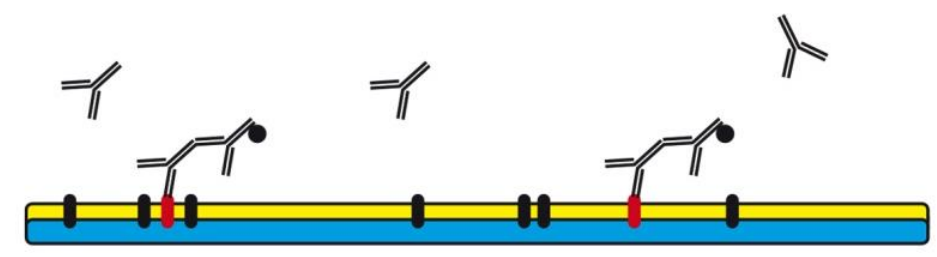

Inkubation mit Sekundärantikörper

Abbildung 8: Schematische Darstellung eines Western Blots. 


\subsubsection{1 Überprüfung der Stoffwechselaktivität mittels MTT-Test}

Der MTT-Test ist ein colorimetrischer Test und wird seit 1983 (Mosmann 1983) für die photometrische Quantifizierung der Stoffwechselaktivität in Zellkultursystemen verwendet.

Die Zellen werden in vitro mit dem namensgebenden gelben, wasserlöslichen Farbstoff 3-(4,5-Dimethylthiazol-2-yl)-2,5-diphenyltetrazolium-bromid (MTT) behandelt, um den Anteil lebender, stoffwechselaktiver Zellen im Vergleich zu einer Kontroll-probe von Zellen zu messen. Die Überprüfung der Stoffwechselaktivität mittels MTT-Test beruht auf einer Reduktion des gelben, wasserlöslichen Farbstoffs in ein blau-violettes, wasserunlösliches Formazan.

Die Reduktion beruht hauptsächlich auf den pyridinhaltigen Reduktionsäquvivalenten NADH und NADPH (Berridge et al. 2005) und nicht wie früher angenommen auf der mitochondrialen Succinat-Dehydrogenasen-Aktivität.

Diese Reduktion kann allerdings nur in lebenden, stoffwechselaktiven Zellen stattfinden, so dass die Quantität dieser Reaktion in einem proportionalen Verhältnis zu der Zahl der vitalen, stoffwechselaktiven Zellen in der Probe steht. Je mehr vitale Zellen also in der Probe vorhanden sind, desto mehr gelbes MTT wird zu einem blauvioletten Formazan reduziert. Innerhalb der Inkubationszeit bilden sich die intrazellulär mikroskopisch gut erkennbaren Farbstoffkristalle. Die Menge des gebildeten Formazans kann dann quantitativ mittels eines Spektrophotometers bestimmt werden.

Der MTT-Test wurde als Verlaufsanalyse zu verschiedenen Zeitpunkten durch-geführt. Gemessen wurden jeweils Octaplicate in einer 96-Well-Flachbodenkultur-platte 96 Stunden, 144 Stunden und 192 Stunden nach Transfektion mit den je-weiligen siRNAs. Da aufgrund der niedrigen Volumina in einer 96-Well-Flachboden-kulturplatte bei einer Transfektion größere Ungenauigkeiten zu erwarten waren, wurde die Transfektion zuerst in einer 6-Well-Flachbodenkulturplatte durchgeführt und die Zellen später umplattiert.

Hierfür wurden die Zellen in einer Dichte von $1 \times 10^{5}$ in $2 \mathrm{ml}$ Kulturmedium pro Well auf einer 6-Well-Flachbodenkulturplatte ausgesät und bei $37^{\circ} \mathrm{C}$ für 22 Stunden im Brutschrank inkubiert. Nach Ablauf dieser Zeit waren die Zellen adhärent und wurden mittels siRNA/RNAiMax/Optimem in der gewählten Konzentration transfiziert.

48 Stunden nach der Transfektion wurden die Zellen auf eine 96-WellFlachbodenkulturplatte zur Durchführung des MTT-Assay umplattiert. Hierzu wurde 
das Medium vorsichtig abgesaugt, die Zellen zweimal gründlich mit PBS gewaschen, mit $200 \mu \mathrm{l}$ Trypsin versetzt und ein bis zwei Minuten in den Brutschrank gestellt. Danach wurden die abgelösten Zellen in $1 \mathrm{ml}$ Medium aufgenommen, vorsichtig vereinzelt und die Zellzahl mit einer Neubauer Zählkammer ermittelt.

Nach Herstellung der Ansätze wurde für jeden Untersuchungszeitpunkt eine eigene 96-Well-Flachbodenkulturplatte mit je 1.000 Zellen pro Well in $200 \mu$ l Medium in Octaplicaten ausplattiert.

Für den Messzeitpunkt Tag 8 nach Transfektion wurde 6 Tage nach Aussaht der Zellen auf der MTP ein Mediumwechsel durchgeführt, um den Zellen genügend Nährstoffe zur Verfügung zu stellen.

Am Tag der Messung wurde $20 \mu \mathrm{l}$ des MTT-Reagenzes pro Well hinzugefügt und für vier Stunden bei $37^{\circ} \mathrm{C}$ im Brutschrank inkubiert. Nach erfolgter Inkubation wurde aus allen Wells das Medium vorsichtig abgesaugt und je Well $100 \mu \mathrm{l}$ 0,1 M Salzsäure in Isopropanol hinzugefügt. Die Platte wurde danach auf den Schüttler gestellt bis sich alle Formazankristalle gelöst hatten, so dass eine Messung am MikrotiterplattenLesegerät (Victor) erfolgen konnte. Bei der photometrischen Messung der Proben wurde die Absorption bei $590 \mathrm{~nm}$ gegen eine Referenzwellenlänge von $660 \mathrm{~nm}$ bestimmt. Mit Hilfe der optischen Dichten (OD) kann dann die Stoffwechselaktivität und somit auch die Zellvitalität berechnet werden.

Jeder MTT-Test wurde mindestens dreimal durchgeführt und in Octaplicaten gemessen. Die Stoffwechselaktivität (\%) der behandelten Zellen wurde aus den ODMittelwerten der Octaplicate der mit Kontroll-siRNA behandelten Kontrollzellen (K) und der behandelten Zellen (E) wie folgt berechnet:

Stoffwechselaktivität (\%) des behandelten Wells $=100 * \frac{E(O D)}{K(O D)}$

\subsubsection{Proliferationsuntersuchung mittels BrdU-Assay}

Der BrdU-Assay misst im Gegensatz zum MTT-Test nicht die Stoffwechselaktivität der vorhandenen Zellen, sondern deren DNA-Synthese als Ausdruck der proliferativen Aktivität. Diese Methode wurde als Alternative zum radioaktiven Thymidin Proliferationsassay entwickelt (Porstmann et al. 1985). Bei diesem Assay wird ein Thymidin-Analogon, das 5-Bromo-2'-deoxyuridin (BrdU), kompetitiv in die DNA eingebaut. Hauptsächlich erfolgt der Einbau während der DNA-Neusynthese bei 
proliferierenden Zellen in der Synthesephase des Zellzyklus. Das von den Zellen eingebaute BrdU wird mittels spezifischer Antikörper, an die Meerrettichperoxidase gekoppelt ist, detektiert. Die an die Antikörper gekoppelte Peroxidase setzt das Substrat Tetramethylbenzidin (TMB) um und bildet ein blaues Endprodukt, welches nach Abstoppen der Reaktion mit Schwefelsäure einen stabilen gelben Farbkomplex bildet. Die Absorption ist nach Abzug des Leerwerts proportional zur Zahl der proliferierenden Zellen in dem jeweiligen Zellkultursystem.

Der BrdU-Assay wurde ähnlich dem MTT-Test als Verlaufsanalyse durchgeführt. Es wurden Octaplicate in einer 96-Well-Flachbodenkulturplatte nach 96 Stunden, 144 Stunden und 192 Stunden nach Transfektion mit den jeweiligen siRNAs ausgewertet. Aufgrund der niedrigen Volumina in einer 96-Well-Flachbodenkulturplatte wurde die Transfektion auch hier zuerst in einer 6-Well-Flachbodenkulturplatte durchgeführt, die Zellen wurden später umplattiert.

Hierfür wurden die Zellen in einer Dichte von $1 \times 10^{5}$ in 2 ml Kulturmedium pro Well auf einer 6-Well-Flachbodenkulturplatte ausgesät und bei $37^{\circ} \mathrm{C}$ für 22 Stunden im Brutschrank inkubiert. Danach wurden die Zellen mit verschiedenen siRNAs der gewählten Konzentration transfiziert.

48 Stunden nach der Transfektion wurden die Zellen auf eine 96-WellFlachbodenkulturplatte umplattiert. Hierzu wurde das Medium vorsichtig abgesaugt, die Zellen zweimal gründlich mit PBS gewaschen, mit $200 \mu \mathrm{l}$ Trypsin versetzt und für ein bis zwei Minuten in den Brutschrank gestellt. Danach wurden die abgelösten Zellen in $1 \mathrm{ml}$ Medium aufgenommen, vorsichtig vereinzelt und die Zellzahl wurde mittels Neubauer Zählkammer ausgezählt.

Für jeden Untersuchungszeitpunkt wurde eine 96-Well-Flachbodenkulturplatte mit je 1.000 Zellen pro Well in $200 \mu \mathrm{l}$ Medium in Octaplicaten ausplattiert. Der letzte Messzeitpunkt wurde 192 Stunden nach Transfektion gewählt. Für diesen Ansatz wurde 96 Stunden nach Umplattierung der Zellen ein Mediumwechsel durchgeführt.

Der Assay wurde nach der Anleitung des Herstellers (Roche Applied Science, Cell Proliferation Elisa, BrdU (colorimetric)) durchgeführt.

Zunächst wurden $20 \mu \mathrm{l}$ des BrdU-Reagenzes pro Well hinzugefügt und für fünf Stunden bei $37^{\circ} \mathrm{C}$ im Brutschrank inkubiert. In dieser Inkubationszeit vollzog sich der Einbau des Pyrimidinanalogons BrdU in die DNA der proliferierenden Zellen anstelle des Thymidins. Nach erfolgter Inkubation wurde das Medium vorsichtig abgesaugt, je 
Well wurden $200 \mu \mathrm{l}$ der zum Kit gehörigen Fixdenat Lösung hinzugefügt. Nach 30 Minuten Inkubation bei Raumtemperatur wurden alle Wells wieder abgesaugt. Nach der Denaturierung der Zellen, durch das mitgelieferte Schnellfixans, wurde je Well $100 \mu \mathrm{l}$ BrdU-Antikörper-Lösung hinzugegeben und 60 Minuten inkubiert. Nach dem erneuten Absaugen der Wells wurden drei Waschgänge mit PBS durchgeführt und durch Zugabe der mitgelieferten TMB-Substratlösung (100 $\mu /$ Well) eine Reaktion zur Detektion der Immunkomplexe ausgelöst. Die Reaktion wurde nach acht Minuten durch Zugabe von $25 \mu \mathrm{l}$ Schwefelsäure $(1 \mathrm{~mol} / \mathrm{l})$ gestoppt und unmittelbar danach wurde die Absorption in einem Mikrotiterplatten-Lesegerät (Sunrise) bei $450 \mathrm{~nm}$ gegen $690 \mathrm{~nm}$ (Referenzwellenlänge) gemessen.

Jeder BrdU-Assay wurde mindestens dreimal in Octaplicaten durchgeführt und gemessen. Die Proliferation (\%) der behandelten Zellen wurde nach Abzug des Leerwertes aus den OD-Mittelwerten der Octaplicate der mit Kontroll-siRNA behandelten Kontrollzellen $(K)$ und der behandelten Zellen $(E)$ wie folgt berechnet:

$$
\text { Proliferation }(\%) \text { des behandelten Wells }=100 * \frac{E(O D)}{K(O D)}
$$

\subsubsection{Bestimmung der Zellzahl und Zellvitalität durch Zellzählung mit Trypanblau-Färbung}

Trypanblau-Färbung ist eine weitere Methode zur Überprüfung der Zellproliferation und der Zellvitalität. Lebende Zellen können den Farbstoff Trypanblau abzuwehren. Tote Zellen hingegen nehmen den Farbstoff auf. Wenn Zellen in der mikroskopischen Betrachtung nach der Farbstoffzugabe bläulich angefärbt sind, zeigt dieses eine Schädigung bzw. den Zelluntergang durch apoptotische oder toxische Prozesse an.

Nach der Plattierung und Transfektion der Zellen, siehe 2.2.11, wurden auch diese Zellen 48 Stunden nach der Transfektion auf eine 6-Well-Flachbodenkulturplatte umplattiert. Um die Versuchsbedingungen zwischen den verschiedenen Methoden möglichst identisch zu halten, wurden 34.360 Zellen in $2 \mathrm{ml}$ Medium pro Well plattiert. Dies entspricht dem Zellzahl/Fläche Verhältnis der Versuche auf einer 96-WellFlachbodenkulturplatte mit 1.000 Zellen/200 $\mu$ l. Es wurden jeweils Triplikate ausplattiert. Insgesamt 192 Stunden nach der Transfektion wurden die Zellen in den Wells gezählt. Hierzu wurde das Medium vorsichtig abgesaugt, zweimal gründlich mit 
PBS gewaschen, die Zellen mit $200 \mu$ trypsinisiert und für ein bis zwei Minuten in den Brutschrank gestellt. Danach wurden die Zellen erneut in Medium aufgenommen und mit Trypanblau angefärbt (10 $\mu$ I Trypanblau und $90 \mu$ Zellen in Medium). Anschließend erfolgte die lichtmikroskopische Zellzählung mittels der Neubauer Zählkammer. Es wurden jeweils alle vier großen Quadrate ausgezählt und aus den Triplikaten ein Mittelwert gebildet.

Jede Trypanblau-Färbung wurde mindestens dreimal durchgeführt und gezählt. Die Ergebnisse der mit MCM3-siRNA behandelten Zellen (E) wurden in Relation zu mit Kontroll-siRNA behandelten Kontrollzellen (K) gesetzt und wie folgt berechnet:

$$
\text { Zellzahl (\%) des behandelten Wells }=100 * \frac{E(\text { Zellzahl })}{K(\text { Zellzahl })}
$$

\subsubsection{Untersuchung auf Apoptose mittels Cell Death Detection ELISA}

Der Cell Death Detection ELISA (CDDE) ist ein Assay mit dem man Apoptose nachweisen kann. Es werden Mono- und Oligonukleosomen, die bei apoptotischen Zellen nach dem Zusammenbruch der Plasmamembran im Zytoplasma entstehen, mit spezifischen Antikörpern nachgewiesen. Bei nekrotischen Zellen können keine Monound Oligonukleosomen nachgewiesen werden.

Durch einen Biotin gekoppelten Anti-Histon-Antikörper werden die Nukleosomen an die Streptavidin beschichtete Oberfläche einer Mikrotiterplatte gebunden. Ein weiterer Peroxidase-gekoppelter Antikörper reagiert mit dem DNA-Anteil der Nukleosomen. Die Antigenmenge und somit die Apoptoseneigung der Zellen kann anschließend anhand der Peroxidase-katalysierten Substratumsetzung relativ quantifiziert werden. Die Messung erfolgt mit einer Wellenlänge von $405 \mathrm{~nm}$ und $490 \mathrm{~nm}$ als Referenzwellenlänge. Der Cell Death Detection ELISA wurde verwendet, um die MCM3-siRNA-induzierte Apoptose im Vergleich zur Basisapoptose zu bestimmen.

Zuerst wurden die zu untersuchenden U87MG-Zellen in einer 6-Well Platte ausplattiert und 22 Stunden später transfiziert. 48 Stunden nach der Transfektion wurden die Zellen auf eine 96-Well-Flachbodenkulturplatte zur Durchführung des CDDE umplattiert.

Für jeden Untersuchungszeitpunkt wurde eine 96-Well-Flachbodenkulturplatte mit je 1.000 bereits transfizierten Zellen pro Well in $200 \mu$ l Medium in Quadruplikaten 
ausplattiert. Die Analyse wurde als Verlaufsuntersuchung durchgeführt. Die Messungen erfolgten wie bei den anderen Versuchen nach 96 Stunden, 144 Stunden und 192 Stunden nach Transfektion mit der jeweiligen siRNA. Für den letzten Ansatz wurde 96 Stunden, nachdem die Zellen umplattiert wurden, ein Mediumwechsel durchgeführt. Zuerst wurde die Mikrotiterplatte zehn Minuten bei $2.500 \mathrm{rpm}$ zentrifugiert. Nachdem das Medium vorsichtig abgesaugt worden ist, wurden die Wells 30 Minuten mit je $200 \mu \mathrm{l}$ Lysispuffer inkubiert und danach erneut zehn Minuten bei $2.500 \mathrm{rpm}$ zentrifugiert. Nach dem zweiten Zentrifugationsschritt wurde der Überstand in ein 1,5 ml-Eppendorfgefäß überführt und $20 \mu \mathrm{l}$ des Überstandes je Well auf die im Kit enthaltene antikörperbeschichtete Mikrotiterplatte überführt. Je Well wurden dann $80 \mu \mathrm{l}$ des Immunreagenzes mit den Antikörpern zu den Proben hinzugefügt und zwei Stunden bei Raumtemperatur auf dem Schüttler (300 rpm) inkubiert. Nach weiteren zwei Stunden Inkubation wurden die Zellen durch Zugabe von Inkubationspuffer zweimal gewaschen. Anschließend wurde das Peroxidase-substrat $(100 \mu \mathrm{l} /$ Well $)$ hinzugegeben und zehn Minuten inkubiert. Die im Kit ent-haltene Positivkontrolle wurde in zwei Wells angelegt. Nach der Inkubation erfolgte die Messung der Absorption. Jeder CDDE-Test wurde mindestens dreimal in Dupli-katen durchgeführt und gemessen.

\subsubsection{Apoptoseuntersuchung mittels cleaved Caspase-3 Western Blot}

Caspase-3 ist eine Effektorprotease und spielt eine wichtige Rolle bei der Apoptoseaktivierung. Sie wird sowohl durch den mitochondrial-vermittelten, als auch durch den Todesrezeptor-vermittelten Signaltransduktionsweg aktiviert. Dabei wird die inaktive Procaspaseform proteolytisch gespalten und es entstehen zwei aktive Spaltprodukte (17 kDa und $19 \mathrm{kDa}$ ).

Die Spaltprodukte können durch spezifische cleaved Caspase-3-Antikörper im Western Blot nachgewiesen werden, wenn eine Apoptose stattgefunden hat.

Der Western Blot wurde wie bereits unter 2.2.10 beschrieben durchgeführt. Die benötigte Positivkontrolle wurde in der Zellkultur mit U87MG-Zellen und 200 nM Staurosporin (Harmalkar und Shirsat 2006) hergestellt. Als primärer Antikörper wurde der cleaved Caspase-3 Antikörper in einer Konzentration von 1:1.000 eingesetzt. Die anderen Antikörperkonzentrationen wurden wie beim MCM3 Western Blot eingesetzt. 
Jeder Caspase-3 Western Blot wurde mindestens dreimal durchgeführt und gemessen.

\subsubsection{Zellzyklusanalyse mittels FACS-Analyse mit Propidiumiodid}

Bei der Durchflusszytometrie, die auch als FACS (Fluorescence Activated Cell Sorting) bezeichnet wird, handelt es sich um die Messung und Analyse von Signalen, die von einzelnen Zellen (oder anderen Partikeln) abgegeben werden. Die Messung erfolgt, wenn die Zellen in einem Flüssigkeitsstrom einen Lichtstrahl passieren (Herzenberg et al. 1976). Für die Messung einer Probe mit einem Durchfluss-zytometer muss diese als Einzelzellsuspension vorliegen. Es sind Partikel mit einem Durchmesser bis zu $1 \mu \mathrm{m}$ differenzierbar. Es können zwei Parameter gemessen werden Streulichtparameter und Fluoreszenzparameter.

Die Streulichtmessung beruht darauf, dass eine Zelle oder ein Partikel mit Licht interagiert. Beim Auftreffen des Lichtstrahls auf die Zelle wird die Richtung des Lichtstrahls verändert und gemessen. Die Wellenlänge des Lichtes wird dadurch hingegen nicht verändert. Dieses macht eine Bestimmung von verschiedenen Zelleigenschaften wie z.B. Zellgröße, Struktur der Zellmembran oder intrazelluläre Bestandteile möglich.

Des Weiteren kann mit einer FACS-Analyse Fluoreszenz gemessen werden. Fluoreszenz entsteht durch das Leuchten eines Stoffes, der mittels Strahlung angeregt wird. Fluoreszierende Verbindungen absorbieren Lichtenergie und heben dabei Elektronen auf ein höheres Energieniveau. Durch das Zurückfallen auf das Grundniveau emittiert das Elektron ein Photon. Die dadurch entstehende Lichtemission bezeichnet man als Fluoreszenz. Jede fluoreszierende Verbindung besitzt einen für sie charakteristischen Wellenlängenbereich. Das Lichtspektrum, über das eine fluoreszierende Verbindung angeregt werden kann, wird Absorptionsspektrum genannt.

Diese Technologie macht es möglich, gleichzeitig physikalische und FluoreszenzParameter sowohl einer einzelnen Zelle als auch einer ganzen Zellpopulation quantitativ zu bestimmen. Es können nukleinsäurebindende, fluoreszierende Farbstoffe eingesetzt werden, um den DNA-Gehalt in einer Zelle zu messen, wodurch Rückschlüsse auf die aktuelle Zellzyklusphase der Zellen gezogen werden können (Nicoletti et al. 1991). Die G1-Phase (Gap 1) ist der Zeitraum zwischen der Kernteilung und der DNA-Synthese. In die G0-Phase treten Zellen, wenn sie sich nicht mehr teilen. 
Dies kann dauerhaft oder nur temporär sein, so dass ein Wiedereintritt in die G1-Phase möglich ist. In der S-Phase (Synthesephase) wird die DNA verdoppelt. Am Ende der S-Phase liegt ein doppelter Chromosomensatz (4n DNA) vor. In der postsynthetischen G2-Phase (Gap 2) wird die nachfolgende Zellteilung (Mitose) vorbereitet. In der MPhase (Mitosephase) findet die Zellteilung statt (Abbildung 9).

\section{M: Mitose}

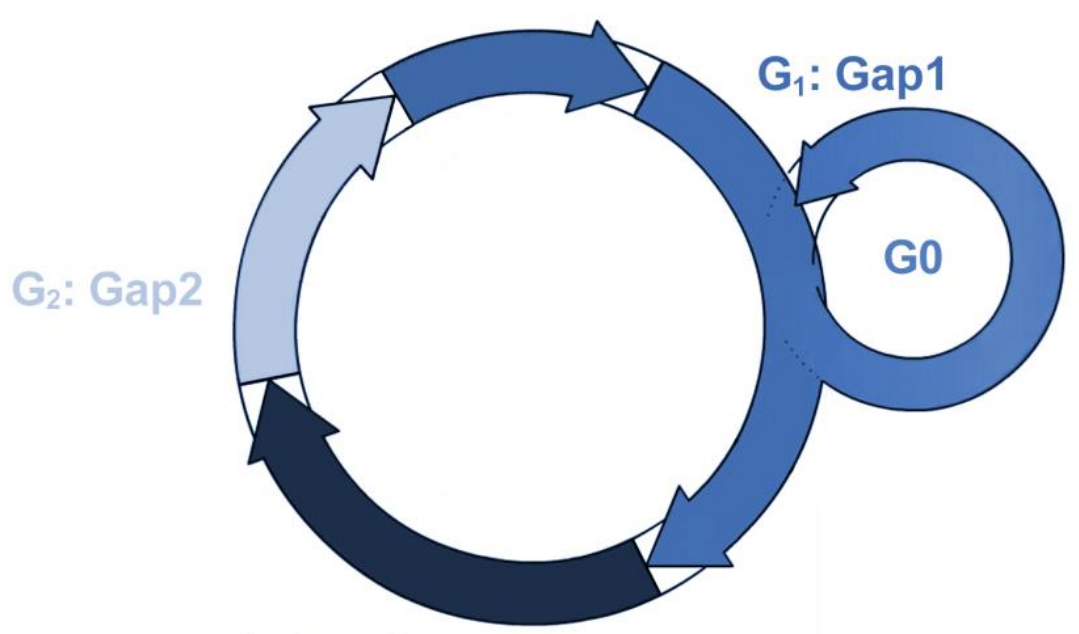

\section{S: Synthese}

Abbildung 9: Schematische Darstellung des Zellzyklus mit den verschiedenen Zellzyklusphasen.

Die Menge an eingelagertem Propidiumjodid ist proportional zum DNA-Gehalt der Zelle. Der DNA-Gehalt einer Zelle ist wiederum abhängig von der Zellzyklusphase, die die Zelle gerade durchläuft. In der G0/G1-Phase liegt ein einfacher Chro-mosomensatz (2n DNA) und in der G2/M-Phase ein doppelter Chromosomensatz (4n DNA) vor (Abbildung 10a und 10b). 


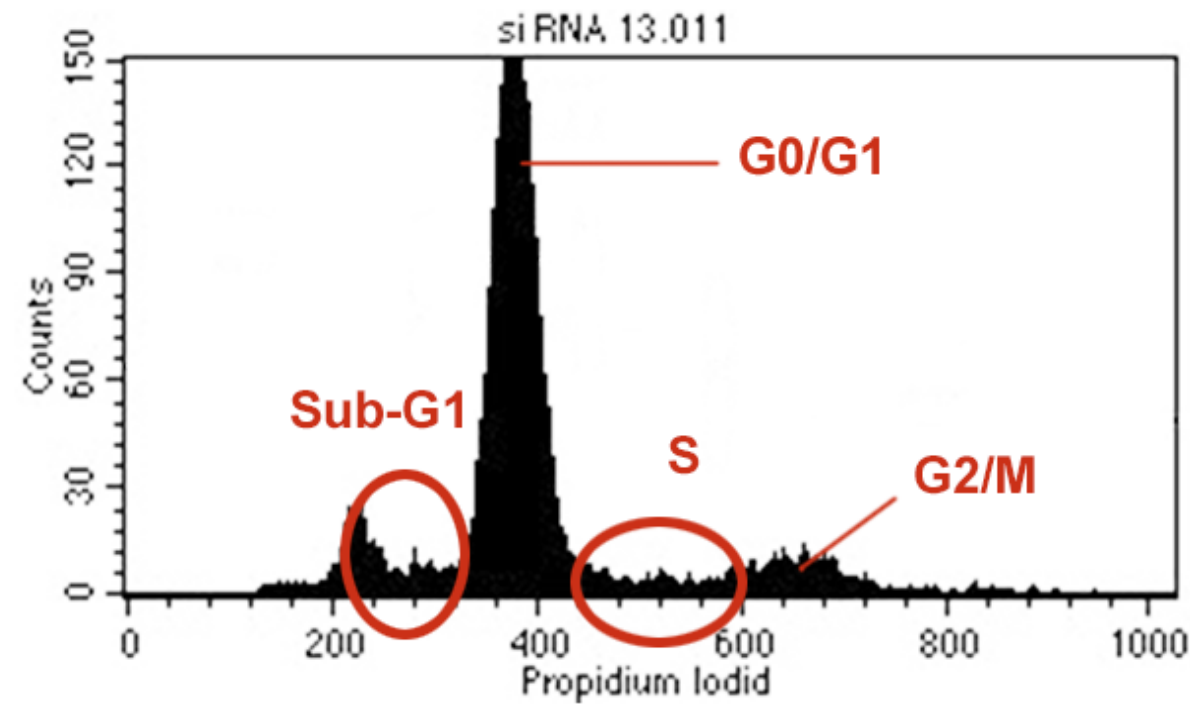

Abbildung 10a: FACS-Analyse zur Bestimmung der Zellzyklusphasen der transfizierten U87MG-Zellen mit Propidiumiodid als Diagramm aufgetragen. Gemessen werden die Menge des eingelagerten Propidiumiodids und die Anzahl der Zellen. Zuordnung zu einer Phase des Zellzyklus je nach Menge des eingelagerten Propidiumiodids. G1/G0-Phase: 2n DNA; G2/M-Phase: 4n DNA, Sub-G1-Phase: apoptotische Zellen.

y-Achse: Anzahl der Zellen, $x$-Achse: logarithmische Darstellung der Fluoreszenz von Propidiumiodid

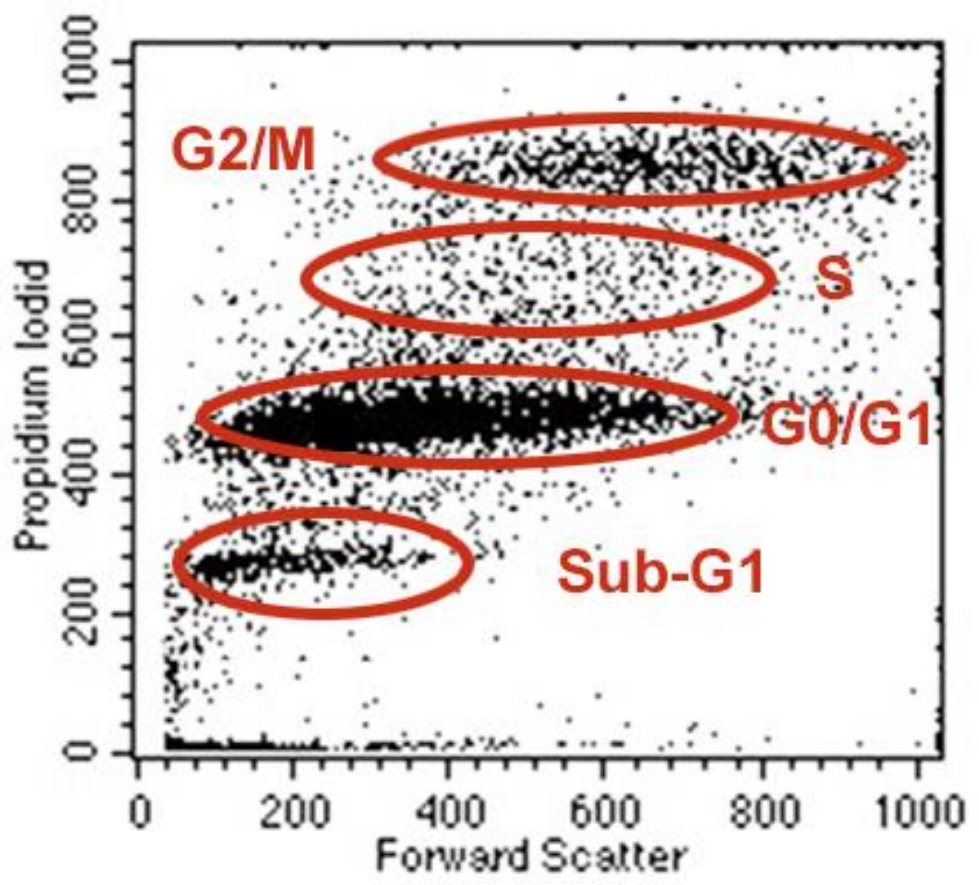

Abbildung 10b: FACS-Analyse zur Bestimmung der Zellzyklusphasen der transfizierten U87MG-Zellen mit Propidiumiodid in Wolkenform. Gemessen werden die Menge des eingelagerten Propidiumiodids und die Größe der Zellen. Zuordnung zu einer Phase des Zellzyklus je nach Menge des eingelagerten Propidiumiodids. G1/G0-Phase: 2n DNA; G2/M-Phase: 4n DNA, Sub-G1-Phase: apoptotische Zellen.

y-Achse: logarithmische Darstellung der Fluoreszenz von Propidiumiodid, $x$-Achse: relative Lichtintensität. 
Die Plattierung und Transfektion der Zellen wurde wie bei den anderen Versuchen durchgeführt. Um die Versuchsbedingungen zwischen den verschiedenen Methoden möglichst vergleichbar zu halten, wurden für die FACS-Analyse die bereits transfizierten Zellen auf eine 6-Well-Platte umplattiert. Dabei wurden 34.360 Zellen in $2 \mathrm{ml}$ Medium pro Well ausplattiert. Dies entspricht dem Verhältnis von Zellzahl pro Fläche der Versuche auf einer 96-Well-Flachbodenkulturplatte mit 1.000 Zellen je $200 \mu$ l.

Die Analyse wurde als Verlaufsuntersuchung an verschiedenen Tagen durchgeführt. Die Messungen erfolgten 96 Stunden und 144 Stunden nach Transfektion mit der jeweiligen MCM3-siRNA. Des Weiteren wurde bei der FACS-Analyse nicht nur die mit Kontroll-siRNA transfizierten Zellen als Referenzwert eingesetzt, sondern auch U87MG-Zellen, die nur mit Liposomen ohne siRNA behandelt wurden, um auszuschließen, dass die Kontroll-siRNA Auswirkungen auf das Zellzyklusverhalten hat.

Die zu untersuchenden Wells wurden nacheinander behandelt. Zuerst wurde das Medium abgesaugt, und die Zellen wurden einmal mit PBS gewaschen. Danach erfolgte die Trypsinisierung und die Aufnahme der Zellen in $1 \mathrm{ml}$ Medium. Die Zellen wurden gezählt und für jeden Ansatz wurden 200.000 Zellen in ein $1,5 \mathrm{ml}$ Eppendorfgefäß überführt. Nach der Zellzählung aller Ansätze, wurde diese für sieben Minuten bei 1.000 rpm zentrifugiert und der Überstand vorsichtig abgesaugt. Das übrig gebliebene Zellpellet wurde in $500 \mu \mathrm{l}$ Nicoletti-Puffer (enthält Propidium-iodid) aufgenommen, vereinzelt und 15 Sekunden gevortext, damit sich das Propidiumiodid gleichmäßig in die DNA einlagert. Danach erfolgte die Zellzyklus-analyse am FACSGerät. Jede FACS-Analyse wurde mindestens dreimal durch-geführt und ausgewertet.

\subsubsection{RNA-Isolierung}

Zur Isolierung der gesamten RNA aus den Zellkulturen wurde das RNeasy-Mini-Kit (Qiagen) benutzt. Bei diesem Verfahren wird die selektive Bindungseigenschaft einer Silikagel-Membran und die Mikrosäulenzentrifugationstechnik in Kombination ausgenutzt. Es wurden die im RNeasy-Mini-Kit vorbereiteten Lyse- und Bindungspuffer zusammen mit den Proben weiterverarbeitet. Über Interaktionen zwischen den RNAMolekülen und den $\mathrm{OH}$-Silkat-Atomen werden Nukleinsäuren selektiv an die SilikagelMembran gebunden. Nach mehreren Wasch- und Säuberungsschritten werden die gereinigten RNA-Molekülstränge mit RNase-freiem Wasser von der Säulenmembran eluiert und weiter verarbeitet. 
Von den adhärenten Zellen wurde zuerst das Medium abgesaugt, die Zellen wurden danach einmal mit PBS gewaschen. Für die Isolierung der RNA wurde TRIzol (TriFast, peqGOLD), eine monophasische Lösung mit Phenol und Guanidin-isothiocyanat benutzt. Die U87MG-Zellen wurden mit $900 \mu \mathrm{l}$ TRIFast abgelöst, gevortext und für zehn Minuten bei $4{ }^{\circ} \mathrm{C}$ und $12.000 \mathrm{rpm}$ zentrifugiert. Nach der Zentrifugation setzte sich ein Überstand ab, in dem sich unter anderem die RNA befand und ein festes Pellet aus Zellresten. Der Überstand wurde in ein neues Röhrchen umpipettiert. Zu jeder Probe wurden nun $200 \mu \mathrm{l}$ Chloroform dazugegeben. Die Probe wurde vorsichtig vermischt, bis die Lösung milchig wurde und danach für weitere 30 Minuten bei Raumtemperatur inkubiert. Nach 15 Minuten Zentrifugation bei $4{ }^{\circ} \mathrm{C}$ und $12.000 \mathrm{rpm}$ bildeten sich drei Phasen. In der unteren roten Phase befand sich das PhenolChloroform-Gemisch und in der trüben Zwischenphase die DNA. In der klaren oberen Phase befand sich die RNA. Diese wurde abpipettiert und zur Fällung der RNA wurde im Volumenverhältnis 1:1 Isopropanol hinzugegeben und gut gemischt.

Die weitere Verarbeitung der Proben erfolgte mit den Puffern und Lösungen des RNeasy Mini Kits. Das Gemisch wurde zunächst in mehreren Schritten auf die im Kit enthaltene Säule pippettiert, zentrifugiert (eine Minute bei Raumtemperatur und 10.000 rpm) und danach gewaschen. Im Anschluss erfolgte die Behandlung mit der im Kit enthaltenen DNase I über 15 Minuten bei Raumtemperatur, um eventuell vorhandene genomische DNA abzubauen. In mehrfachen Zentrifugationsschritten unter Zugabe von Waschpufferlösungen wurden Salze, Proteine und andere zelluläre Bestandteile von der Membran entfernt. Nach einer Lufttrocknung bei Raumtemperatur wurde das RNA-Sediment in $40 \mu \mathrm{l}$ Rnase-freiem Wasser von der Säule losgelöst. Dieser Schritt wurde zur Maximierung der Ausbeute an RNA nochmals wiederholt.

Die Konzentration der RNA wurde danach mittels NanoDrop ND-1000Spektrophotometer bei $260 / 280 \mathrm{~nm}$ bestimmt. Die RNA wurde sofort weiterver-arbeitet oder bis zum Gebrauch bei $-80^{\circ} \mathrm{C}$ aufbewahrt.

\subsubsection{RNA-Konzentrationbestimmung mittels NanoDrop}

Die Konzentrationsbestimmungen der isolierten RNA-Proben erfolgten mit dem NanoDrop-ND-1000-Spektrophotometer. Für eine Messung wurden $2 \mu \mathrm{l}$ der oben beschriebenen Lösung eingesetzt. Die RNA-Konzentration wird durch Absorptions- 
messung bei der Wellenlänge $260 \mathrm{~nm}$ bestimmt. Eine Absorptionseinheit A260 entspricht $40 \mu \mathrm{g} \mathrm{RNA} / \mathrm{ml}$.

Der Absorptionsquotient A260/A280 für reine RNA sollte 1,9-2,1 betragen. Alle Messungen wurden als Duplikate bestimmt durchgeführt.

\subsubsection{Real-time Polymerase-Kettenreaktion zur Bestimmung der Expressionshemmung von MCM3-mRNA}

Die real-time Polymerase-Kettenreaktion (real-time RT-PCR) ist ein molekulargenetisches Verfahren, bei dem bestimmte DNA Abschnitte gezielt vervielfältigt werden. Durch die exponentielle Vervielfältigung von geringen Mengen DNA, können DNA Abschnitte nachweisbar gemacht oder für andere Zwecke genutzt werden.

Die RT-PCR besteht aus drei aufeinanderfolgenden Arbeitsschritten, die mehrfach wiederholt werden: Auftrennung der DNA-Stränge (Denaturierung), Anlagern der Primer (Annealing) und Verdopplung der DNA (Elongation).

Zunächst muss die DNA in der Denaturierungs-Phase entwunden werden. Die Neusynthese von DNA erfolgt dann über zwei synthetische Oligonukleotide, sogenannte Primer, die in der Annealing-Phase sich an die einzelnen DNA-Stränge anlagern. Man wählt die Primer für die real-time RT-PCR so aus, dass sie sequenzspezifisch an den zu vervielfältigenden Bereich der DNA angrenzen. Mittels DNA-Polymerasen wird in der Elongations-Phase die DNA dann vervielfältigt. (Abbildung 11). Es werden 20 bis 30 Zyklen pro Untersuchung durchgeführt.

Um mit Hilfe der Polymerase-Kettenreaktion das genetische Material zu verviel-fältigen und zu untersuchen, muss zunächst die RNA aus der Zellkultur oder dem Gewebe isoliert werden. Anschließend wird die isolierte RNA mittels der reversen Transkription in complementery DNA (cDNA) umgeschrieben und danach mit Hilfe der PolymeraseKettenreaktion amplifiziert. 


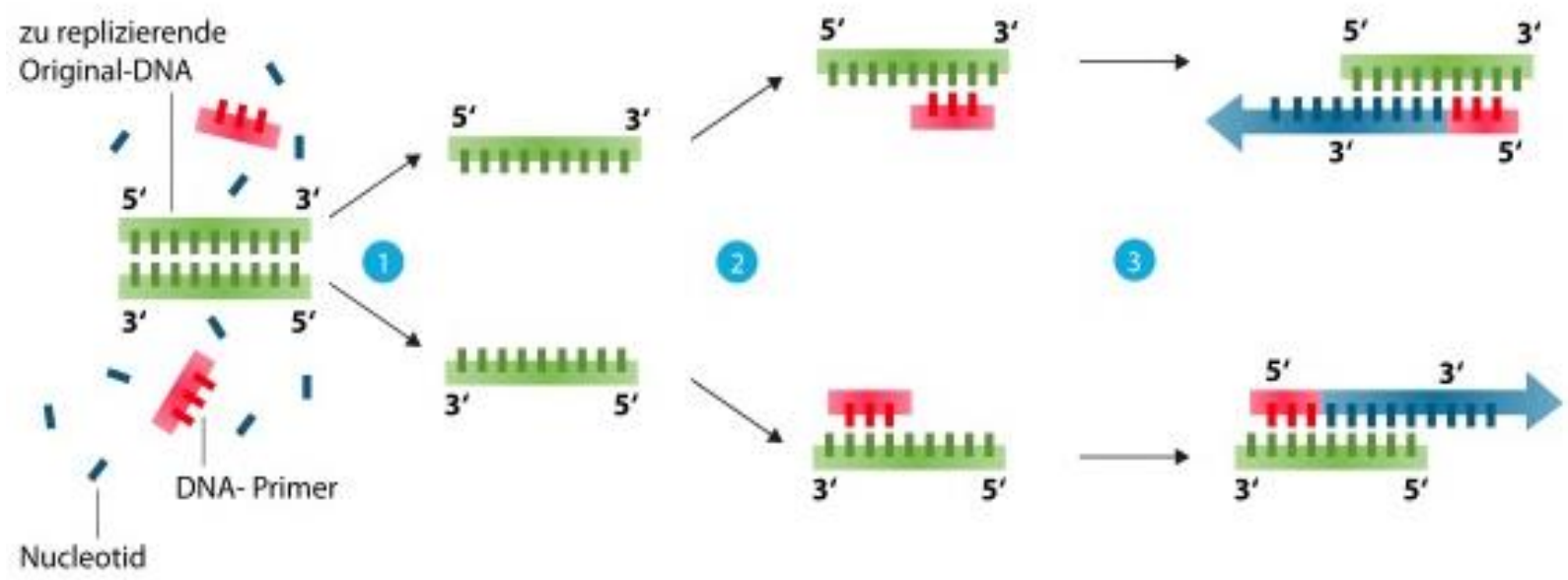

Abbildung 11: Schema einer Polymerase-Kettenreaktion. Schritt 1: Denaturierung, Schritt 2 Primerhybridisierung, Schritt 3 Elongation. Modifiziert nach http://de.wikipedia.org/wiki/Polymerase-Kettenreaktion.

Die Messung der DNA-Menge im Verlauf der real-time RT-PCR basiert auf der Verwendung des Fluoreszenzfarbstoffs SYBR Green. SYBR Green ist ein interkalierender Farbstoff, der sich in die Doppel-Helix einlagert und bei Anregung Licht der Wellenlänge $521 \mathrm{~nm}$ emittiert. Die Intensität des emittierten Lichts kann mittels LightCycler gemessen werden. Das Fluoreszenzsignal wird am Ende der Elongationsphase nach jedem Zyklus gemessen, wenn die maximale amplifizierte Menge an doppelsträngiger DNA vorliegt. Während der Denaturierung löst sich der SYBR Green-Farbstoff wieder aus der DNA. Freie Farbstoffmoleküle senden eine geringe Fluoreszenz aus, die computergestützt vom Zielsignal abgezogen wird (Abbildung 12).

Des Weiteren muss die Spezifität der SYBR Green-Polymerase-Kettenreaktion kontrolliert werden. Dies erfolgt im LightCycler im Anschluss an jede real-time RT-PCR über eine Analyse der Schmelztemperatur. Hierzu wird das Amplifikat (doppelsträngige DNA) über eine kontinuierliche Temperaturerhöhung geschmolzen. Dabei bestimmt die Länge, die Sequenz und der GC-Gehalt des DNA-Doppelstranges seine Schmelztemperatur. Zeigt die Schmelztemperaturkurve (Abbildung 13) viele Gipfel so wurden ggf. unspezifische Produkte amplifiziert. Ein zweiter, einzelner kleiner Gipfel hingegen, meist bei geringerer Temperatur als der des gewünschten Produktes, ist durch die no template control-Probe (NTC) zu erklären. Der Peak ist durch PrimerDimer entstanden. 


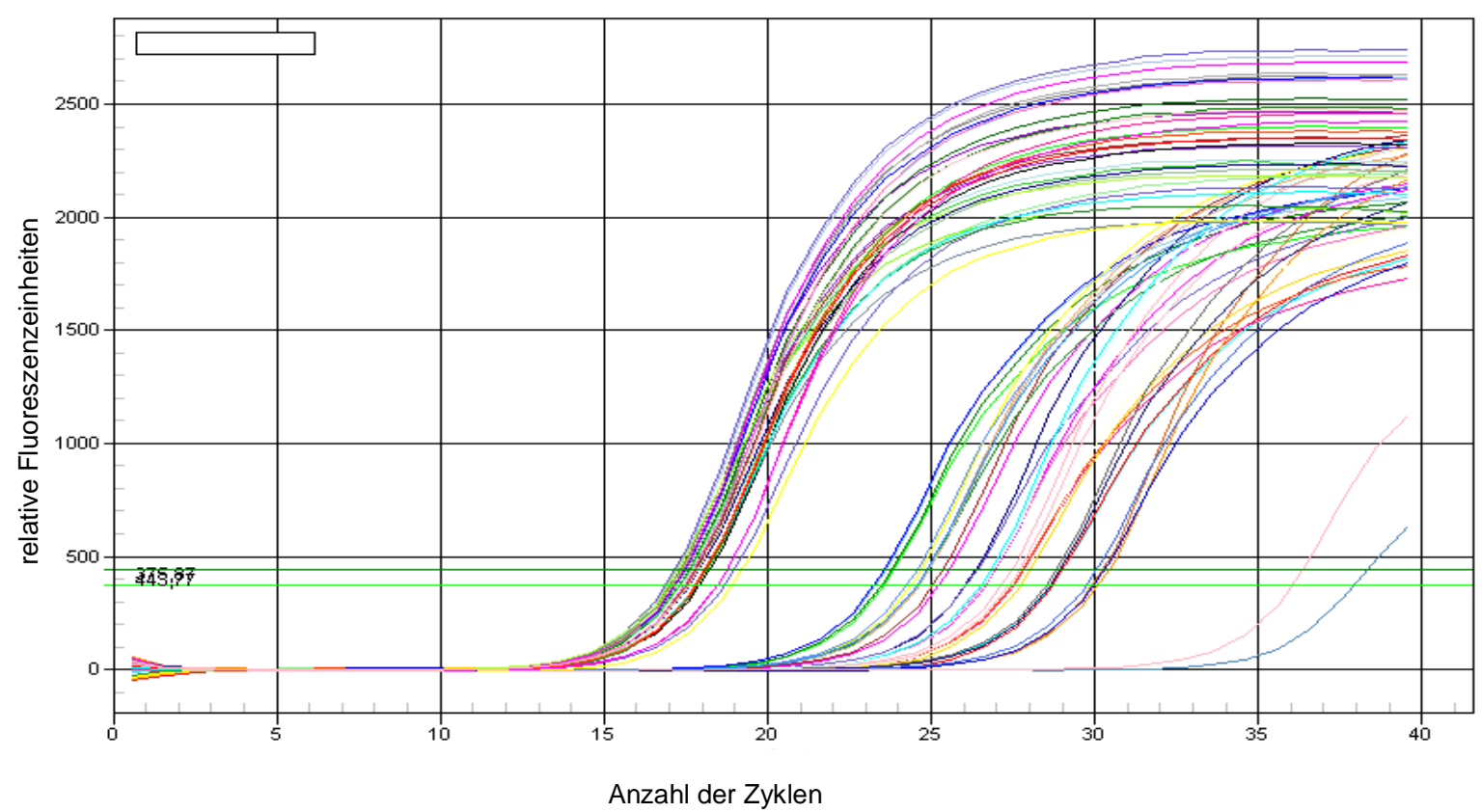

Abbildung 12: Real-time RT-PCR zur Bestimmung der MCM3-mRNA nach Transfektion der U87MG-Zellen mit Kontroll-siRNA (20 nM), MCM3-siRNA 13 (10 nM) und MCM3siRNA $15(20 \mathrm{nM})$. Es wurden 2 Produkte vervielfältigt GAPDH-mRNA (1. Kurve) und MCM3-mRNA (2. Kurve). GAPDH-mRNA wurde als housekeeping gene bestimmt. yAchse: relative Fluoreszenzeinheiten, $x$-Achse: Anzahl der Zyklen.

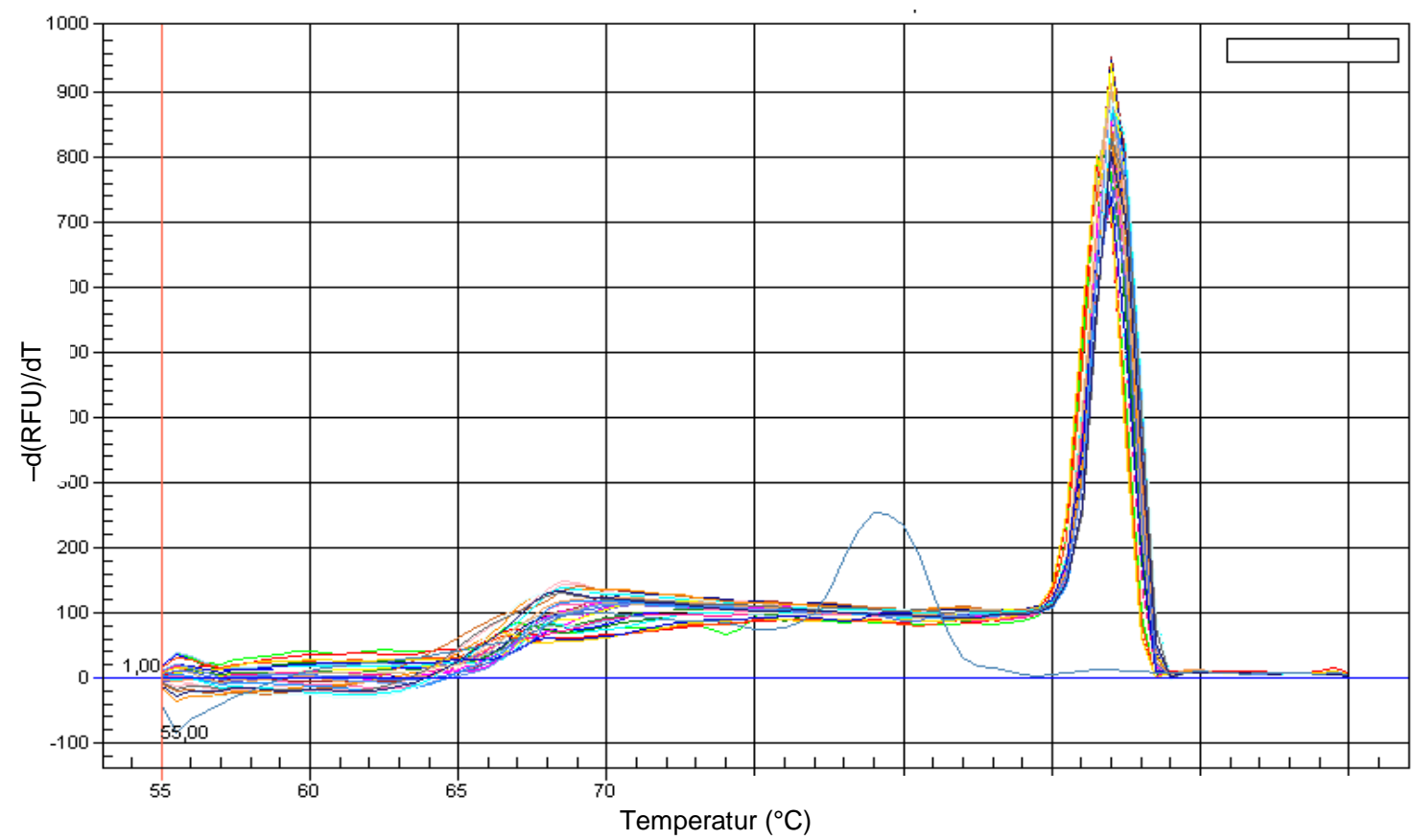

Abbildung 13: Schmelzkurve nach real-time RT-PCR von MCM3-siRNA transfizierten U87MG-Zellen mit Primern für MCM3. In der Probe wurde nur ein Produkt amplifiziert. Die blaue einzelne Kurve ist der Peak durch PrimerDimer der NTC.

y-Achse: -d(RFU)/dT (Änderung der relativen Fluoreszenzeinheiten (RFU) mit der Zeit $(\mathrm{T}))$, $\mathrm{x}$-Achse: Temperatur $\left({ }^{\circ} \mathrm{C}\right)$.

Nachdem die RNA gewonnen wurde, erfolgte die Umschreibung in cDNA mittels der reversen Transkription (Superscrit II von Invitrogen). Zunächst wurde die RNA mit 
Ampuwa-Wasser verdünnt, so dass $1 \mu \mathrm{g}$ RNA in $10 \mu \mathrm{l}$ Lösung enthalten war. Nachfolgend wurden zu der verdünnten RNA $1 \mu \mathrm{l}$ Random Primer (300 $\mathrm{ng} / \mu \mathrm{l})$ und $1 \mu \mathrm{l}$ verdünnte Desoxyribonukleosidtriphosphate (dNTP, hergestellt aus $10 \mu \mathrm{l}$ NTP $+60 \mu \mathrm{l}$ $\mathrm{H}_{2} \mathrm{O}$ ) hinzugegeben und für fünf Minuten auf $65^{\circ} \mathrm{C}$ erhitzt. Im nächsten Schritt erfolgte die Zugabe von $7 \mu$ leines Mastermixes, bestehend aus $4 \mu \mathrm{l}$ 5x Puffer, $2 \mu \mathrm{l}$ 0,1 M DTT (beides im Superscrit II Kit von Invitrogen enthalten) und $1 \mu$ l Rnase out (Invitrogen). Danach wurde das Gemisch für zwei Minuten auf $42{ }^{\circ} \mathrm{C}$ erhitzt. Als letzter Schritt erfolgte die Zugabe von $1 \mu$ Superscript II. Danach wurde der Mix für 50 Minuten auf $42{ }^{\circ} \mathrm{C}$ und für 15 Minuten auf $72{ }^{\circ} \mathrm{C}$ erhitzt. Nach anschließender Abkühlung auf $4{ }^{\circ} \mathrm{C}$ war die Umschreibung in cDNA beendet.

Im Anschluss wurden für die Durchführung der real-time RT-PCR die Primer für MCM3 und GAPDH je 1:10 vorverdünnt. GAPDH wurde dabei als housekeeping gene eingesetzt. Gemessen wurde je Probe ein Volumen von $25 \mu$ l. Dieses bestand aus $5 \mu \mathrm{l}$ Probe und $20 \mu \mathrm{l}$ Mastermix aus Primern (je 0,5 $\mu \mathrm{l}, 100 \mathrm{pmol} / \mu \mathrm{l}$ ), sterilem Wasser $(6,5 \mu l)$ und SYBR Green $(12,5 \mu \mathrm{l})$.

Nun konnte die umgeschriebene RNA mit Hilfe der RT-PCR amplifiziert werden. Zuerst wurde das Reaktionsgemisch zur Denaturierung auf $94{ }^{\circ} \mathrm{C}$ erhitzt. Bei dieser Temperatur trennten sich die DNA-Stränge der cDNA vollständig voneinander. Sie bildeten Einzelstränge, die zu den Vorlagen für die DNA-Polymerase und die Primer werden. Danach wurde die Temperatur gesenkt, damit die Primer an die komplementären Sequenzen der DNA-Moleküle binden konnten. Diese AnnealingTemperatur bestimmt entscheidend die Spezifität der real-time RT-PCR. Bei einer zu niedrigen Temperatur kann es zu unspezifischen Bindungen der Primer kommen und damit zu gegebenenfalls unerwünschten Produkten. Ist die Temperatur hingegen zu hoch, entsteht kein Produkt. Im letzten Schritt wurde die Temperatur auf $72^{\circ} \mathrm{C}$ erhöht, damit die DNA-Synthese erfolgen konnte. Unter der optimalen Temperatur fand die Elongation durch die hitzestabile DNA-Polymerase statt. Der ganze Zyklus mit Erhitzung zur Trennung der Stränge (Denaturierung), Bindung der Primer (Annealing) und Synthese mit Hilfe der DNA-Polymerase (Elongation) wurde mehrfach (20 bis 30 Zyklen) wiederholt. Jede real-time RT-PCR-Untersuchung wurde mindestens dreimal durchgeführt und ausgewertet. 
Die Ergebnisse (E) der aus mit MCM3-siRNA behandelten Zellen wurden in Relation zur Kontrolle, mit Kontroll-siRNA behandelte Zellen, (K) gesetzt und wie folgt nach der $\Delta$ Ct-Methode berechnet:

1. $\Delta \mathrm{Ct}$ berechnet: $\Delta \mathrm{Ct}=\mathrm{Ct} \mathrm{E}(\mathrm{MCM} 3)-\mathrm{Ct} \mathrm{K}(\mathrm{GAPDH})$

2. $\quad$ RNA Expression in $(\%)=100 * \frac{2^{-\Delta \mathrm{Ct}(\mathrm{E})}}{2^{-\Delta \mathrm{Ct}(\mathrm{K})}}$

\subsubsection{0 Überprüfung des Langzeitüberlebens mittels Clonogenic Assay}

Mit diesem Versuch wurde die Fähigkeit einzelner Zellen untersucht, sich nach Vorbehandlung mit MCM3-siRNA zu einer Kolonie zu vermehren. Damit wurde die Langzeitwirkung der in den Vitalitäts- und Proliferations-Assays gesehenen Effekte der eingesetzten MCM3-siRNAs überprüft, da der Versuch erst nach 14 Tagen ausgewertet wurde. Dazu wurden die behandelten Zellen auf einer Argaroseschicht ausgesät und das Überleben der einzelnen Klone im Vergleich zu den Kontrollzellen evaluiert. Es wurden nur Kolonien gezählt, die mindestens 50 Zellen groß waren. Es wird davon ausgegangen, dass eine Kolonie aus einer einzelnen Zelle entstanden ist.

Zunächst wurde eine Grundschicht bestehend aus 1,5 $\mathrm{ml}$ 0,5\% Agarose in DMEM mit $10 \%$ FCS in einer Vertiefung einer 6-Well-Microtiterplatte ausgegossen. Während diese Grundschicht auskühlte, wurde die Oberschicht mit Zellen angemischt. Diese

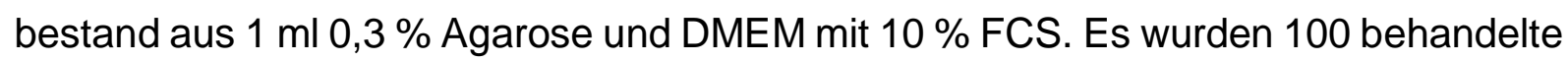
Zellen hinzugegeben und im Brutschrank für 14 Tage bebrütet. Zweimal pro Woche wurde 0,5 ml DMEM mit $10 \%$ FCS hinzugegeben, um den behandelten U87MG-Zellen genug Nährstoffe zur Verfügung zu stellen. Die Kolonie bildenden Einheiten wurden nach 14 Tagen mittels Umkehrmikroskop bei 100-facher Vergrößerung ausgezählt. Es wurden jeweils Triplikate ausgezählt.

Jeder Clonogenic Assay wurde mindestens dreimal durchgeführt und ausgewertet. Die Ergebnisse der aus mit MCM3-siRNA behandelten Zellen entstandenen Kolonien ( $E$ ) wurden in Relation zur Kontrolle, mit Kontroll-siRNA behandelte Zellen, (K) gesetzt und wie folgt berechnet: 


$$
\text { Kolonien (\%) der behandelten Zellen }=100 * \frac{E(\text { Anzahl der Kolonien })}{K(\text { Anzahl der Kolonien })}
$$

\subsubsection{Statistik}

Messwerte wurden als Mittelwert mit Standardabweichung angegeben. Alle Versuche wurden mindestens dreimal durchgeführt. Bei kinetischen Untersuchungen wurde für jeden Messzeitpunkt eine eigene Zellkultur/Probe angelegt. 


\section{Ergebnisse}

\subsection{MCM3-Suppression in U87MG-Zellen durch MCM3-siRNA 13 und}

\section{MCM3-siRNA 15}

Zur quantitativen Analyse von MCM3 wurde zunächst ein Western Blot etabliert. Es wurde gezeigt, dass definierte Mengen an Protein geladen, geblottet und dann auch genau quantifiziert werden können. Um die Beladung der Membran vor dem Western Blot zu überprüfen, wurde eine Ponceau-S-Färbung durchgeführt (Abbildung 14).
A $\quad$ B $\quad$ C $\quad$ D $\quad F$

$123 \mathrm{kDa} \rightarrow$

$50 \mathrm{kDa} \rightarrow$

$17 \mathrm{kDa} \rightarrow$

Abbildung 14: Ponceau-S-Färbung einer PVDFMembran. A) Roti@-Mark prestained Marker, aufgetragenes U87MG-Zelllysat mit den Proteinmengen B) $20 \mu \mathrm{g}$, C) $5 \mu \mathrm{g}$, D) $10 \mu \mathrm{g}$, F) $20 \mu \mathrm{g}$. Unterschiedliche Ladungsmengen regelrecht abgebildet mit unterschiedlich intensiver Färbung bei gleichmäßiger Bandenverteilung. Je kräftiger die Banden abgebildet sind, desto mehr Protein wurde geladen.

Nach einer Reihe von Vorversuchen zur Bestimmung der optimalen Konzentration der Primar- und Sekundärantikörper erwiesen sich folgende Konzentrationen als zuverlässig (Tabelle 8).

\begin{tabular}{|l|l|l|l|}
\hline Primärantikörper & Primärantikörper & Sekundärantikörper & Sekundärantikörper \\
\hline a-Tubulin-AK & MCM3-Antiserum & Anti-Rabbit-AK & Anti-Mouse-AK \\
\hline $1: 1.000$ & $1: 4.000$ & $1: 1.000$ & $1: 10.000$ \\
\hline
\end{tabular}

Tabelle 8: Eingesetzte Antikörperkonzentrationen bei MCM3-Western Blots. 
Es wurde zunächst U87MG-Zelllysat mit $20 \mu \mathrm{g}, 10 \mu \mathrm{g}$ und $5 \mu \mathrm{g}$ Protein auf das Gel geladen und mittels Western Blot geblottet (Abbildung 15). Es konnte gezeigt werden, dass mit diesem Versuchsaufbau eine enge Korrelation zwischen der geladenen und quantifizierten Proteinmenge dargestellt werden kann (Tabelle 9).

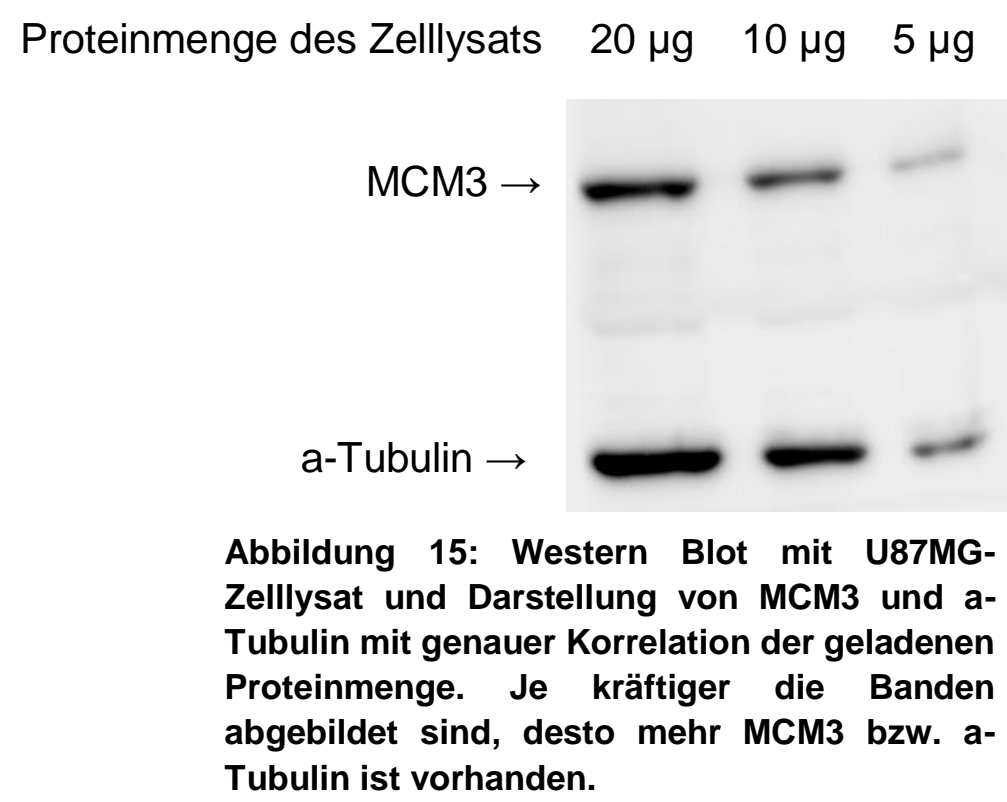

\begin{tabular}{|c|c|c|c|c|}
\hline \multirow{4}{*}{ MCM3 } & $\begin{array}{c}\text { Protein } \\
(\boldsymbol{\mu g})\end{array}$ & Fläche MCM3 & $\begin{array}{c}\text { gemessene } \\
\text { Pixel }\end{array}$ & relative Intensität \\
\cline { 2 - 5 } & 20 & 4928 & 145487 & 1,00 \\
\cline { 2 - 5 } & 10 & 3060 & 75423 & 0,52 \\
\cline { 2 - 5 } & 2 & 2380 & 16137 & 0,11 \\
\hline
\end{tabular}

\begin{tabular}{|c|c|c|c|c|}
\hline & $\begin{array}{c}\text { Protein } \\
(\boldsymbol{\mu g})\end{array}$ & Fläche a-Tubulin & $\begin{array}{c}\text { gemessene } \\
\text { Pixel }\end{array}$ & relative Intensität \\
\cline { 2 - 5 } a-Tubulin & 20 & 5428 & 152501 & 1,00 \\
\cline { 2 - 5 } & 10 & 3264 & 79368 & 0,52 \\
\cline { 2 - 5 } & 2 & 1860 & 20458 & 0,13 \\
\hline
\end{tabular}

Tabelle 9: Quantifizierung des Western Blots. Es zeigt sich eine genaue Korrelation der geladenen Proteinmenge und der Anzahl der gemessenen Pixel. Somit konnte gezeigt werden, dass definierte Mengen an Protein geladen und genau quantifiziert werden können.

Nachdem bei der Quantifizierung der unterschiedlich geladenen Mengen an Protein aus dem U87MG-Zelllysat eine enge Korrelation zu den Erwartungswerten gezeigt werden konnte, wurden nun die mittels Zellkultur hergestellten MCM3-siRNA behandelten Proben vermessen. 
Die Untersuchungen wurden zunächst mit 5 verschiedenen MCM3-siRNAs (MCM3siRNA 10, MCM3-siRNA 13, MCM3-siRNA 15, MCM3-siRNA 16 und MCM3siRNA 3'UT) und einer Kontroll-siRNA durchgeführt.

Es ist bekannt, dass siRNAs beim Einsatz in sehr hoher Konzentration ab $100 \mathrm{nM}$ sogenannte off-target-Effekte verursachen. Die höchste eingesetzte Konzentration betrug $50 \mathrm{nM}$ und war damit weit unter der kritischen Grenze von $100 \mathrm{nM}$. Zunächst wurde die MCM3-siRNA mit dem höchsten Effekt bezüglich einer MCM3-Suppression bestimmt. Des Weiteren wurde die optimale Konzentration der jeweiligen MCM3siRNA mit der höchsten Suppression des MCM3 gesucht. Es wurden alle 5 MCM3siRNAs in den Konzentrationen 0,1 nM, $1 \mathrm{nM}, 10 \mathrm{nM}, 20 \mathrm{nM}, 30 \mathrm{nM}$ und $50 \mathrm{nM}$ eingesetzt und bezüglich ihrer Wirkung analysiert (Abbildung 16). Die Untersuchung ergab, dass die MCM3-siRNA 13 beim Einsatz $10 \mathrm{nM}$ und die MCM3-siRNA 15 beim Einsatz von $20 \mathrm{nM}$ die höchste Suppression an MCM3 aufwiesen. Die maximale Suppression bei MCM3-siRNA 13 lag bei 93,0\% und die der MCM3-siRNA 15 bei 84,3\% (Abbildung 17). Im späteren Verlauf der Untersuchungen wurden die Versuche nur noch mit den siRNAs MCM3-siRNA 13 und MCM3-siRNA 15 in den jeweiligen Konzentrationen fortgesetzt.

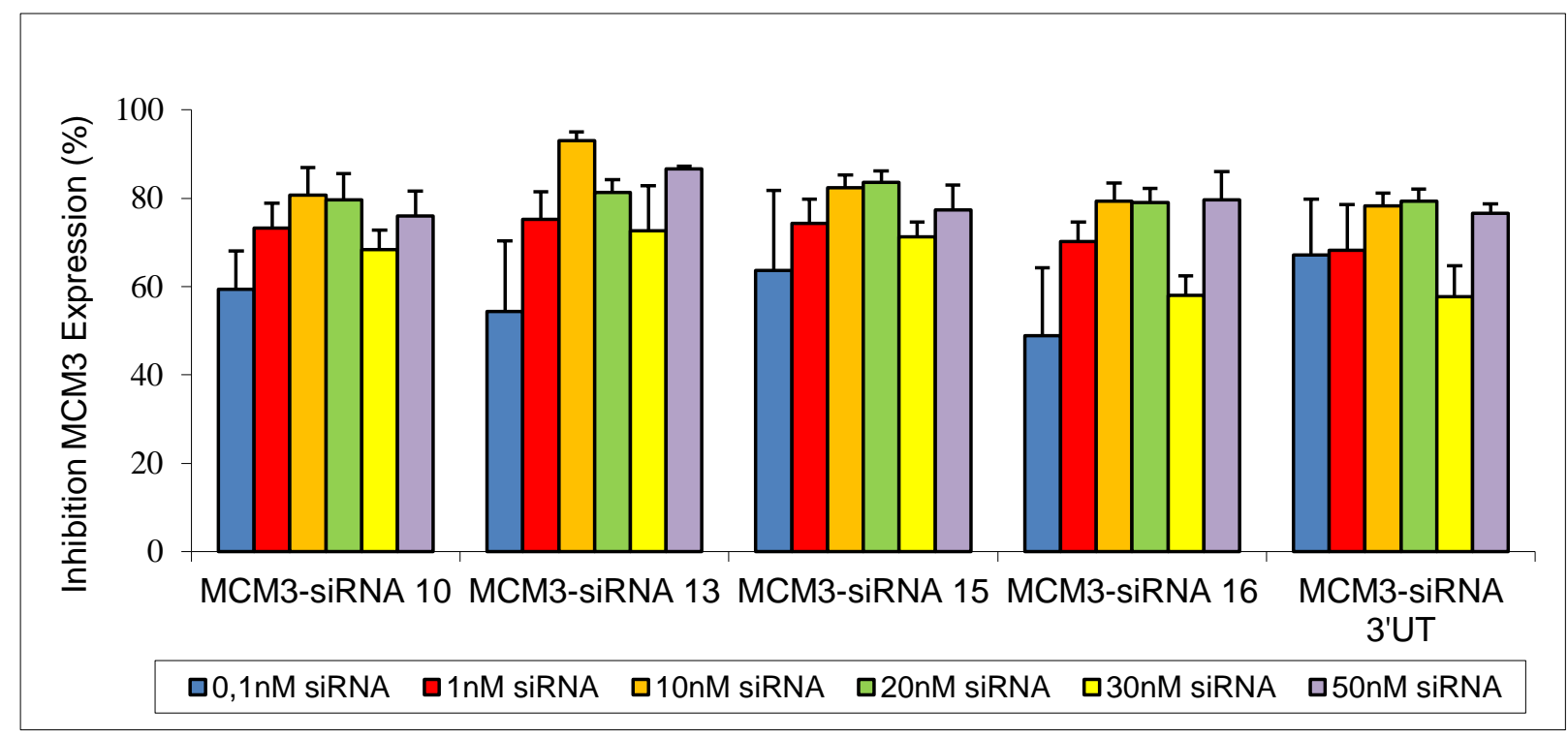

Abbildung 16: Inhibition der MCM3-Proteinexpression in U87MG-Zellen durch spezifische MCM3siRNAs im Vergleich zu Kontroll-siRNA transfizierten U87MG-Zellen. Quantifizierung mittels Western Blot und ImageJ. y-Achse: Inhibition der MCM3 Expression in \% der Kontrolle; $x$-Achse: eingesetzte MCM3-siRNA. 


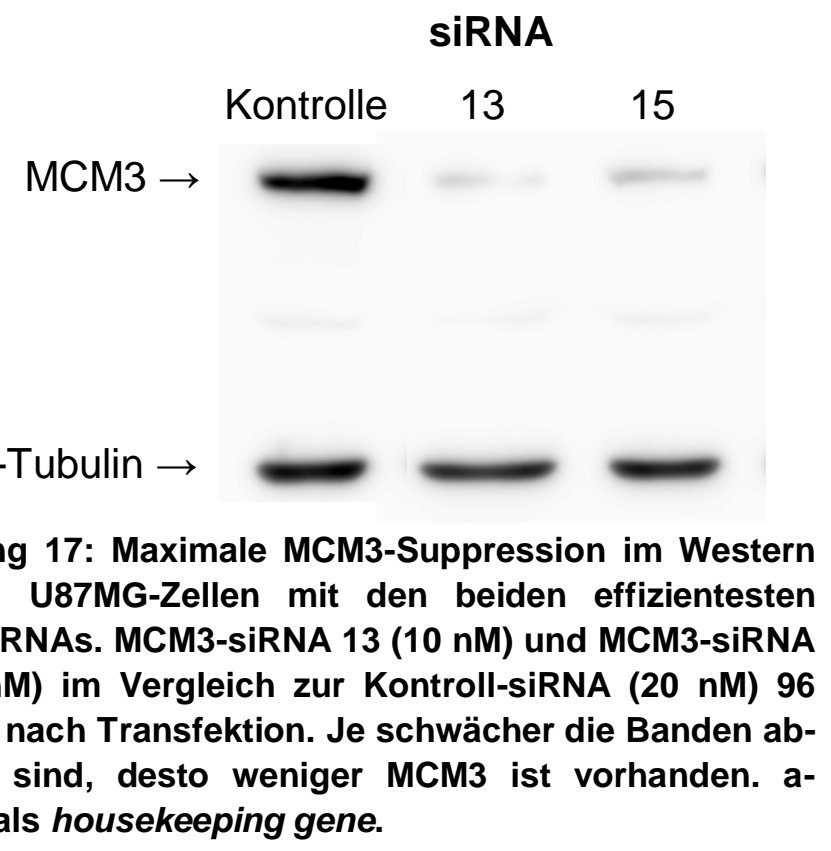

Abbildung 17: Maximale MCM3-Suppression im Western Blot bei U87MG-Zellen mit den beiden effizientesten MCM3-siRNAs. MCM3-siRNA 13 (10 nM) und MCM3-siRNA $15(20 \mathrm{nM})$ im Vergleich zur Kontroll-siRNA (20 nM) 96 Stunden nach Transfektion. Je schwächer die Banden abgebildet sind, desto weniger MCM3 ist vorhanden. aTubulin als housekeeping gene.

Um sicherzustellen, dass die Kontroll-siRNA die notwendigen Voraussetzungen erfüllt, wurde die Kontroll-siRNA ebenfalls in verschiedenen Konzentrationen ( 0 nM (nur Lipofectamine RNAiMAX), 0,1 nM, 1 nM, 20 nM, $50 \mathrm{nM}$ und $100 \mathrm{nM}$ ) eingesetzt. Das Ergebnis zeigte, dass es bei allen eingesetzten Konzentrationen keine Effekte der Kontroll-siRNA gab (Abbildung 18).

\section{Kontroll-siRNA}

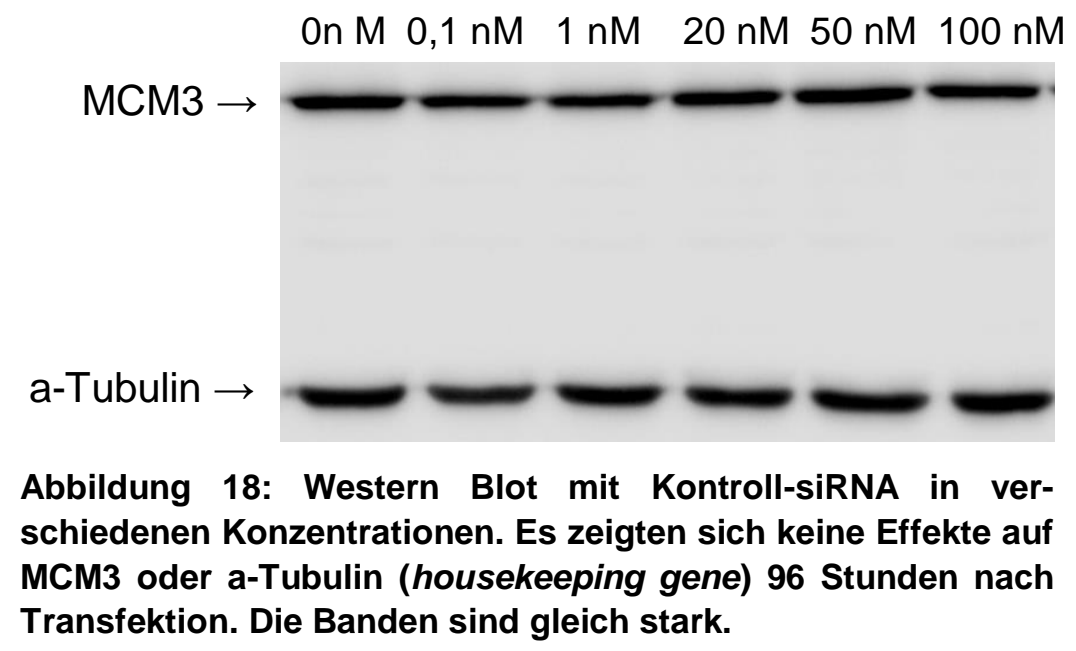

Die behandelten U87MG-Zellen wurden jeweils 96 Stunden nach der Transfektion geerntet. In einer Kinetikuntersuchung konnte gezeigt werden, dass die MCM3Suppression im Verlauf zunimmt und nach 96 Stunden die höchste Suppression des MCM3 vorliegt (Abbildung 19 und 20). In weiteren Versuchen wurde gezeigt, dass 
Suppression von MCM3 nach 120 Stunden nicht mehr signifikant zunahm (Daten nicht gezeigt).

\begin{abstract}
MCM3-siRNA 13
$24 \mathrm{~h} \quad 48 \mathrm{~h} \quad 72 \mathrm{~h} \quad 96 \mathrm{~h}$ Kontroll-siRNA

$\mathrm{MCM} 3 \rightarrow$

a-Tubulin $\rightarrow$

Abbildung 19: Kinetikuntersuchung von transfizierten U87MGZellen mit Kontroll-siRNA (20 nM) und MCM3-siRNA 13 (10 nM) mittels Western Blot. Messzeitpunkte waren 24 Stunden, 48 Stunden, 72 Stunden und 96 Stunden nach Transfektion. Je schwächer die Banden abgebildet sind, desto weniger MCM3 ist vorhanden. a-Tubulin als housekeeping gene.
\end{abstract}

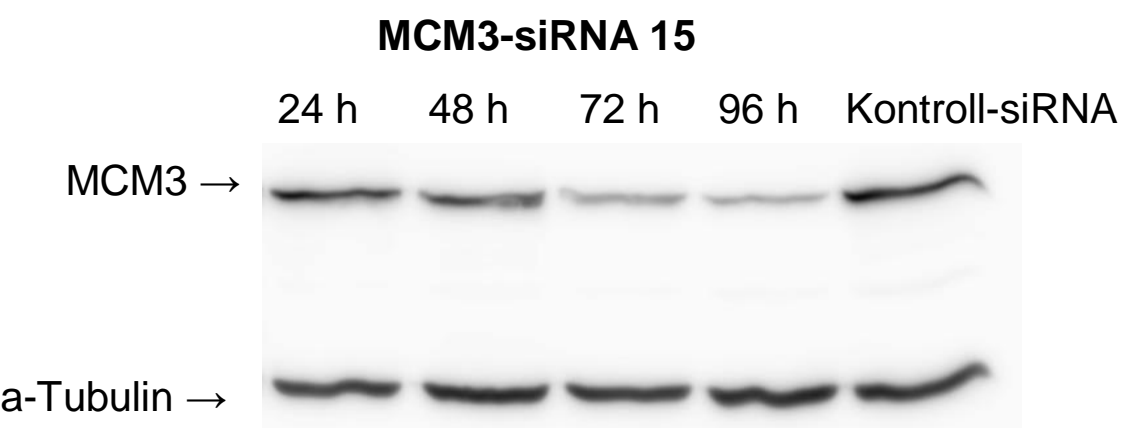

Abbildung 20: Kinetikuntersuchung von transfizierten U87MGZellen mit Kontroll-siRNA (20 nM) und MCM3-siRNA 15 (20 nM) mittels Western Blot. Messzeitpunkte waren 24 Stunden, 48 Stunden, 72 Stunden und 96 Stunden nach Transfektion. Je schwächer die Banden abgebildet sind, desto weniger MCM3 ist vorhanden. a-Tubulin als housekeeping gene.

Zusammenfassend lassen sich folgende Ergebnisse des Western Blots festhalten:

1. Mit dem beschrieben Versuchsaufbau konnte eine enge Korrelation bei der Quantifizierung zwischen Erwartungs- und Messwerten dargestellt werden.

2. Mit den beiden wirksamsten MCM3-siRNAs (MCM3-siRNA 13 und MCM3siRNA 15) konnte eine hohe Suppression von MCM3 erreicht werden.

3. Die eingesetzte Kontroll-siRNA zeigt auch bei höheren Konzentrationen keine supprimierende Wirkung auf MCM3 oder a-Tubulin.

4. Off-target Effekte sind aufgrund der beschriebenen Ergebnisse mit den eingesetzten Konzentrationen unwahrscheinlich. 
5. Der Zeitpunkt 96 Stunden nach Transfektion, ist der Zeitpunkt der höchsten Suppression von MCM3.

Im Folgenden wurden alle Versuche nur mit den beiden effektivsten MCM3-siRNAs MCM3-siRNA 13 (10 nM) und MCM3-siRNA 15 (20 nM) durchgeführt. Im Verlauf wurde überprüft, ob die Suppression von MCM3, die auf Proteinebene fast vollständig erfolgt, Auswirkungen auf die Stoffwechselaktivität, Vitalität, Proliferation, Zellzyklus und Apoptoseinduktion der U87MG-Zellen hat.

\subsection{Stoffwechselaktivität der U87MG-Zellen nach Behandlung mit MCM3-siRNA 13 und 15 im MTT-Test}

Der MTT-Test wurde zur Bestimmung der Stoffwechselaktivität der mit MCM3siRNA 13 und 15 behandelten U87MG-Zellen durchgeführt. Da MCM3 entscheidend am Zellzyklus beteiligt ist und erst nach der Suppression des Proteins Auswirkungen auf die Stoffwechselaktivität zu erwarten sind, erfolgte die Messung an Tag 4 (96 Stunden), Tag 6 (144 Stunden) und an Tag 8 (192 Stunden) nach Transfektion. Da die mit Kontroll-siRNA transfizierten Zellen an Tag 8 nach Transfektion fast konfluent waren, war eine Messung der Stoffwechselaktivität über diesen Zeitraum hinaus nicht möglich. Die Bildung der Formazankristalle korreliert mit der Stoffwechsel-aktivität bzw. der Anzahl stoffwechselaktiver Zellen.

Es zeigten sich geringere optische Dichten (OD) bei beiden eingesetzten MCM3siRNAs. Die MCM3-siRNA 13, die die stärkste Suppression des MCM3 auf Proteinebene bewirkte, bewirkte auch im MTT-Test die niedrigste OD und somit die niedrigste Stoffwechselaktivität der Zellen. Die Stoffwechselaktivität, der mit MCM3siRNA 13 behandelten Zellen lag minimal bei $21,4 \%$ an Tag 8 (Abbildung 21 und 22) und zeigte einen stetig sinkenden Verlauf. Die mit MCM3-siRNA 15 behandelten U87MG-Zellen zeigten ebenfalls eine erniedrigte OD (Abbildung 21 und 22). Allerdings lag die minimale Stoffwechselaktivität mit $65,4 \%$ an Tag 6 deutlich über der von MCM3-siRNA 13. Dieses korrelierte mit den Ergebnissen des Western Blots, da die MCM3-siRNA 13 mit $93 \%$ auch die deutlich höhere Suppression auf Proteinebene zeigte. An Tag 8 kam es bei den MCM3-siRNA 15 behandelten Zellen zu einem Anstieg der Stoffwechselaktivität. 


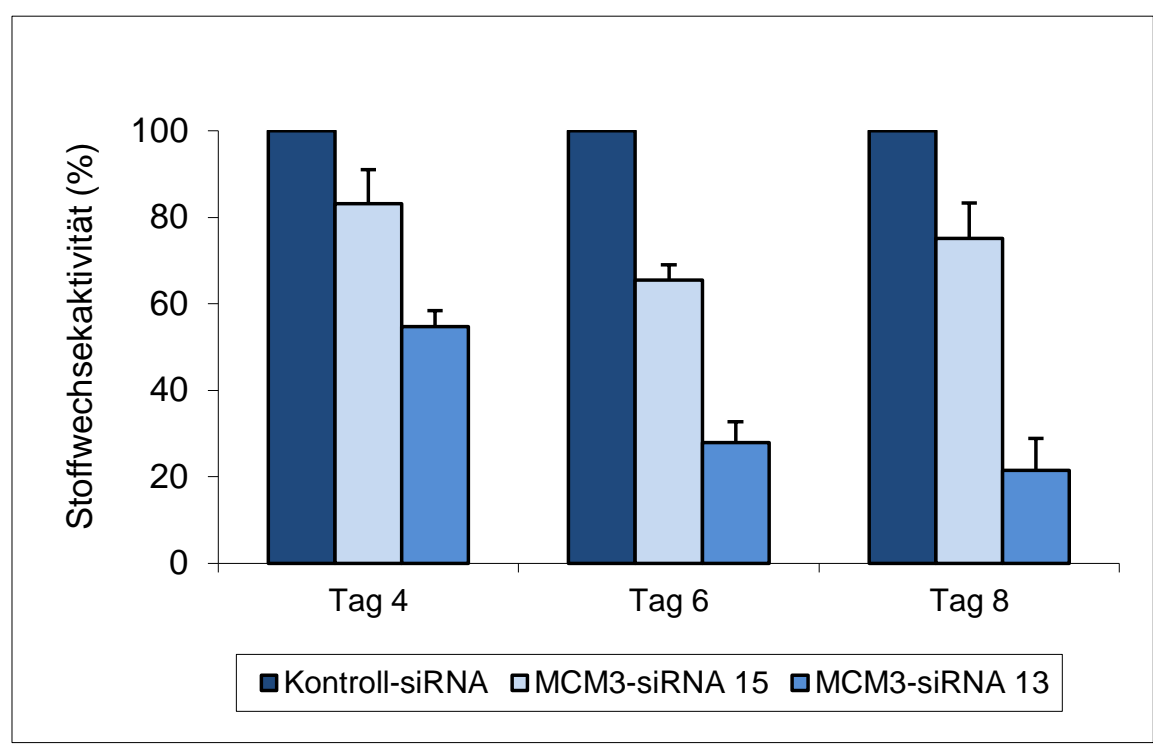

Abbildung 21: MTT-Test zur Überprüfung der Stoffwechselaktivität an Tag 4, Tag 6 und Tag 8 nach Transfektion der U87MG-Zellen. Eingesetzt wurden Kontroll-siRNA (20 nM), MCM3-siRNA 15 (20 nM) und MCM3-siRNA 13 (10 nM). y-Achse: Stoffwechselaktivität in \% der Kontrolle; $x$-Achse: Tag nach Transfektion mit MCM3-siRNA.

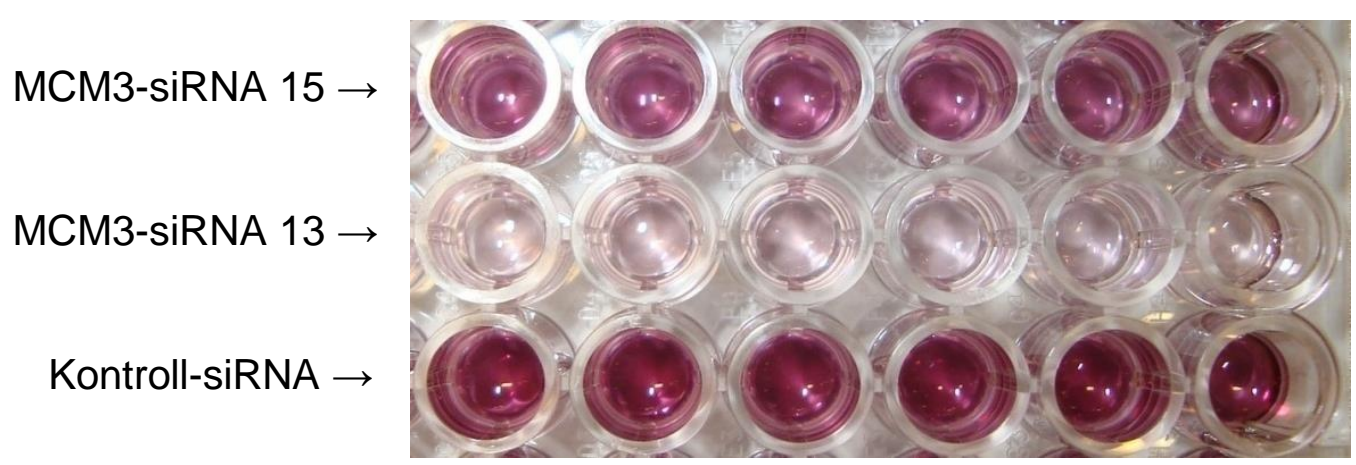

Abbildung 22: MTT-Test zur Überprüfung der Stoffwechselaktivität an Tag 8 nach Transfektion der U87MG-Zellen mit Kontroll-siRNA (20 nM), MCM3-siRNA 13 (10 nM) und MCM3-siRNA 15 (20 nM). Die Färbung durch violettes Formazan wird umso kräftiger, je höher die Stoffwechselaktivität der behandelten U87MG-Zellen ist.

Wie die Ergebnisse des MTT-Tests zeigen, hat die Suppression von MCM3 deutliche Auswirkungen auf die Stoffwechselaktivität. Die Suppression von MCM3 führte zu einer hohen Reduktion der Stoffwechselaktivität. Dieses wurde im Verlauf durch weitere Versuche genauer untersucht. 


\subsection{Proliferation der U87MG-Zellen bei Behandlung mit MCM3- siRNA 13 und 15 im BrdU-Assay}

Im Vergleich zum MTT-Test wird beim BrdU-Assay nicht die Stoffwechselaktivität, sondern die Proliferationsfähigkeit der Zellen untersucht, da der Assay auf dem kompetitiven Einbau eines Thymidin-Analogons, dem 5-Bromo-2'-deoxyuridin, in die DNA beruht. Die Messung erfolgte an Tag 4 (96 Stunden), Tag 6 (144 Stunden) und an Tag 8 (192 Stunden) nach Transfektion, um eine möglichst gute Vergleichbarkeit zum MTT-Test zu erhalten. Auch hier war eine Messung der Zellproliferation über diesen Zeitraum hinaus nicht möglich, da die mit Kontroll-siRNA transfizierten Zellen am Tag 8 nach Transfektion fast konfluent waren.

Beide siRNAs zeigten eine hemmende Wirkung auf die Proliferation. Die niedrigste Proliferation wurde bei MCM3-siRNA 13 bereits an Tag 4 nach Transfektion erreicht. Diese betrug nur 13,1 \% in Bezug auf die mit Kontroll-siRNA behandelten U87MGZellen. Der höchste antiproliferative Effekt trat im Vergleich zur niedrigsten Stoffwechselaktivität im MTT-Test schon früher auf. Im Verlauf der Untersuchung stieg die Proliferationsfähigkeit der MCM3-siRNA 13 behandelten Zellen wieder auf maximal $21,6 \%$ an (Abbildung 23 und 24). Für MCM3-siRNA 15 zeigte sich an Tag 6 die deutlichste Proliferationshemmung mit $64,1 \%(68,1 \%$ an Tag 4). Diese blieb im weiteren Verlauf fast stabil und lag an Tag 8 bei $65,5 \%$ (Abbildung 23 und 24).

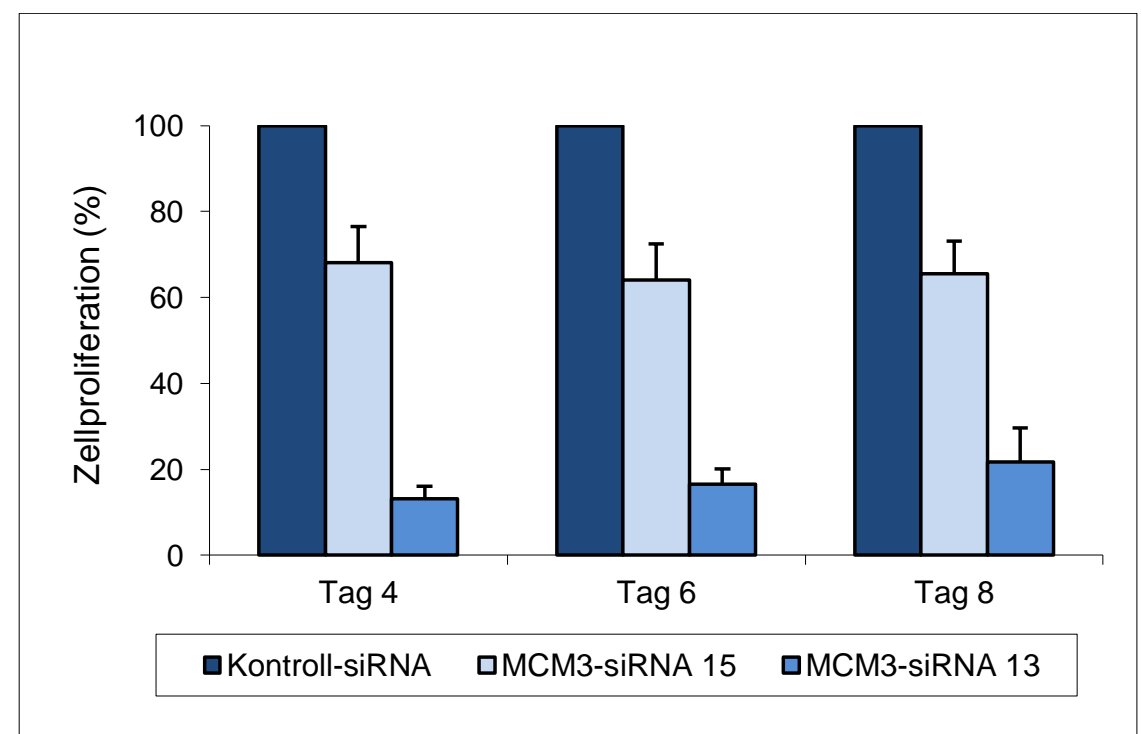

Abbildung 23: BrdU-Assay zur Überprüfung der Proliferationsfähigkeit von U87MG-Zellen an Tag 4, Tag 6 und Tag 8 nach Transfektion mit Kontroll-siRNA (20 nM), MCM3-siRNA 15 (20 nM) und MCM3-siRNA 13 (10 nM). y-Achse: Zellproliferation in \% der Kontrolle; $x$-Achse: Tag nach Transfektion mit MCM3-siRNA. 


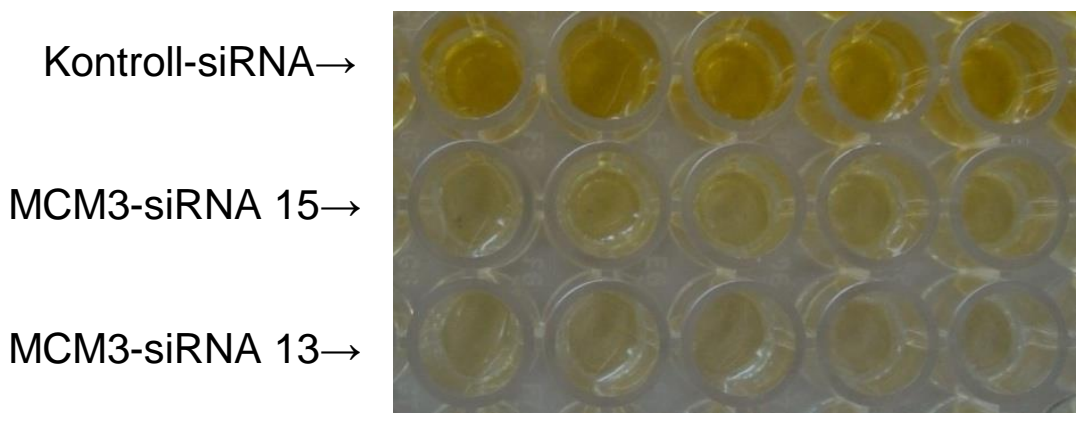

Abbildung 24: BrdU-Assay zur Überprüfung der Proliferationsfähigkeit an Tag 8 nach Transfektion mit Kontroll-siRNA (20 nM), MCM3-siRNA 15 (20 nM) und MCM3-siRNA 13 (10 nM). Je intensiver die Gelbfärbung, desto höher ist die Proliferation der behandelten U87MG-Zellen.

\subsection{Trypanblau-Färbung der U87MG-Zellen nach Transfektion mit MCM3-siRNA 13 und 15 zur Bestimmung der Zellzahl und Vitalität}

Mit der Trypanblau-Färbung wurde ein weiterer Versuch zur Überprüfung der Zellproliferation und der Zellvitalität durchgeführt. Lebende Zellen sind für diesen Farbstoff nicht zugänglich, tote Zellen hingegen nehmen den Farbstoff auf. Des Weiteren wurde die absolute Zellzahl der verschiedenen Versuchsreihen ermittelt. Die Zellzählung und Messung der Trypanblau-Einlagerung wurde nicht als Kinetik durchgeführt, sondern lediglich an Tag 8 ausgewertet. Auch bei diesem Versuch war eine Durchführung über diesen Zeitraum hinaus nicht möglich, da die mit KontrollsiRNA transfizierten Zellen an Tag 8 nach Transfektion sehr dicht gewachsen waren. Bei der lichtmikroskopischen Zählung fiel auf, dass sowohl bei den mit MCM3siRNA 13 als auch bei den mit MCM3-siRNA 15 behandelten U87MG-Zellen sehr wenig tote bzw. blau angefärbte Zellen ( $<8 \%$ ) zu sehen waren. Allerdings zeigte sich, dass bei den behandelten Zellen im Vergleich zur Kontrolle insgesamt deutlich weniger Zellen zu sehen waren. Für die mit MCM3-siRNA 15 behandelten Zellen ergab sich eine Zellzahl von 42,6 \% im Vergleich zur Kontrollgruppe. Bei den MCM3-siRNA 13behandelten U87MG-Zellen zeigte sich eine Zellzahl von nur noch 8,3 \% im Vergleich zur Kontrolle (Abbildung 25).

Wie bereits im MTT-Test und BrdU-Assay dargestellt werden konnte, ergaben sich im Trypanblau-Versuch ebenfalls Hinweise auf einen Proliferationsstopp der behandelten U87MG-Zellen, da bei MCM3-siRNA 13 nur 8,3\% der Zellen gezählt werden konnten, aber nur sehr wenige blau angefärbte Zellen zu sehen waren. Auch korreliert die deutlich höhere Effektivität von MCM3-siRNA 13 mit den zuvor durchgeführten 
Versuchen. Es ergaben sich keine Hinweise für einen program-mierten Zelltod im Sinne von apoptotischen Zellen. Diese Untersuchungsergebnisse korrelieren mit den anderen Tests, da die reduzierte Zellzahl bei MCM3-siRNA trans-fizierten U87MGZellen auf eine Proliferationshemmung hinweist. Für eine Induktion von Apoptose ergaben sich keine Hinweise, da nur sehr wenige tote Zellen bei der Zählung dargestellt werden konnten. Es wurden weitere Versuche zur Überprüfung von Apoptose durchgeführt.

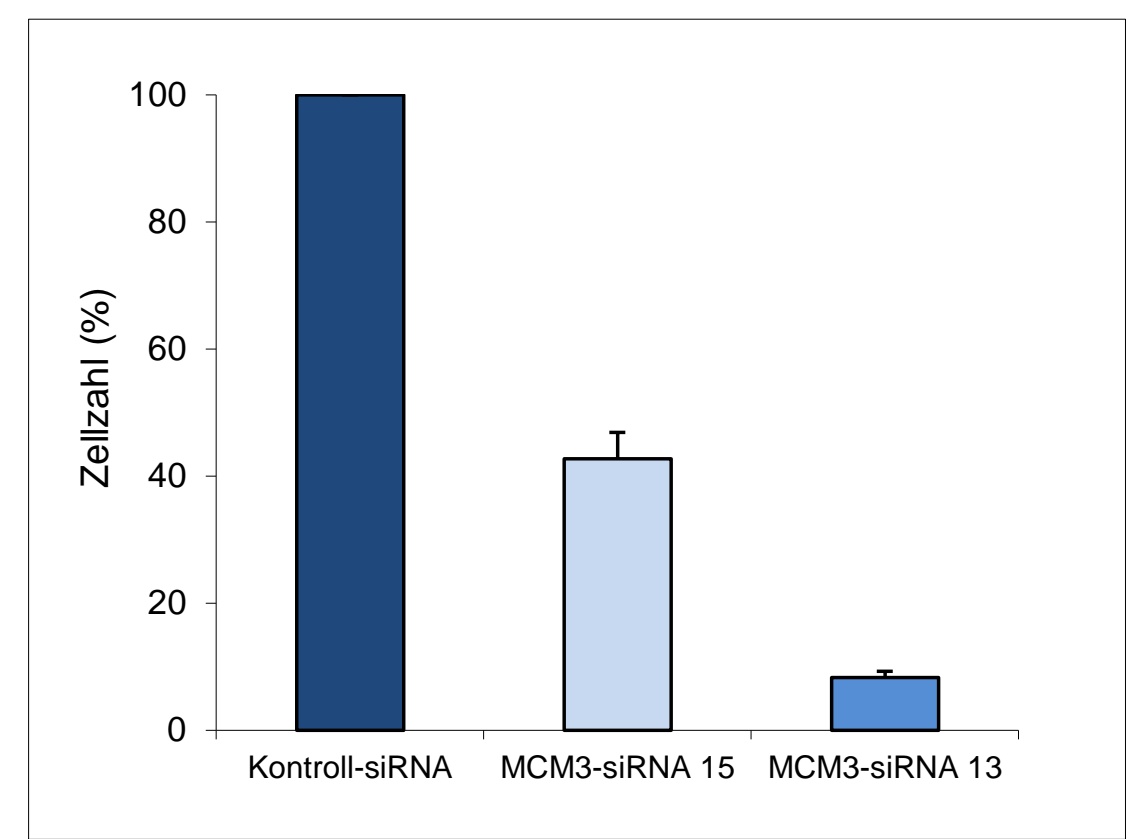

Abbildung 25: Zellzählung mit Trypanblaufärbung an Tag 8 nach Transfektion von U87MG-Zellen mit Kontroll-siRNA (20 nM), MCM3siRNA 15 (20 nM) und MCM3-siRNA 13 (10 nM). Es zeigt sich eine deutlich verringerte Zellzahl der behandelten U87MG- Zellen. yAchse: Zellzahl in \% der Kontrolle; x-Achse: eingesetzte MCM3SiRNA. 


\subsection{Messung der Apoptoserate nach Behandlung der U87MG-Zellen mit MCM3-siRNA 13 und 15 im Cell Death Detection ELISA}

Mit diesem Test wurde untersucht, ob die mit MCM3-siRNA behandelten U87MGZellen apoptotisch werden oder nur einen Proliferationsstopp zeigen. Mit Hilfe des CDDE-Tests werden Mono- und Oligonukleosomen nachgewiesen, die nach dem Zusammenbruch der Plasmamembran im Zytoplasma von apoptotischen Zellen entstehen, nicht aber bei nekrotischen Zellen. Auch beim CDDE-Test wurden die transfizierten Zellen und die Kontrolle nach 96 Stunden, 144 Stunden und 192 Stunden untersucht.

Bei den behandelten U87MG-Zellen konnte für beide MCM3-siRNAs mittels CDDETest keine Apoptose nachgewiesen werden. Bei den mit MCM3-siRNA transfizierten Zellen zeigte sich eine optische Dichte, die nicht oberhalb des Leerwertes lag, wohingegen die Positivkontrolle eine deutliche Peroxidaseaktivität und damit Bildung von Nukleosomen aufwies (Abbildung 26). Dieses Ergebnis korreliert mit den vorangegangenen Versuchen, die einen Proliferationsstop zeigten, aber keinen Hinweis auf eine Apoptoseinduktion ergaben. Dieses Ergebnis wurde durch weitere Untersuchungen überprüft.

Positivkontrolle Negativkontrolle MCM3-siRNA $13 \quad$ MCM3-siRNA 15

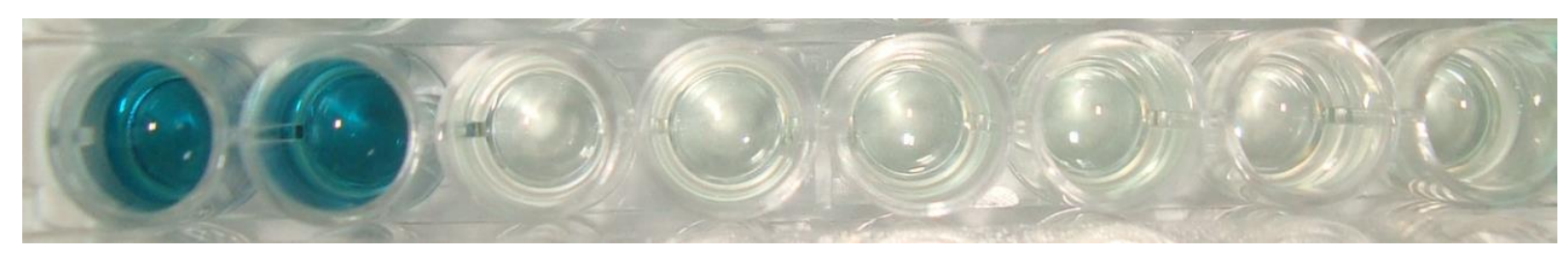

Abbildung 26: CDDE an Tag 8 nach Transfektion mit MCM3-siRNA 13 (10 nM) und MCM3siRNA 15 (20 nM). Es zeigt sich keine bläuliche Färbung wie bei der Positivkontrolle, die eine Apoptose der behandelten U87MG-Zellen anzeigt. 


\title{
3.6 Überprüfung der Apoptoseinduktion im cleaved Caspase-3 Western Blot
}

Im Western Blot konnten die Banden der cleaved Caspase-3 bei der Positivkontrolle gut gezeigt werden. Bei den mit MCM3-siRNA behandelten U87MG-Zellen konnten keine Caspase-Spaltprodukte nachgewiesen werden (Abbildung 27). Dies korrelierte mit den bisherigen Untersuchungsergebnissen wie z.B. den Daten aus dem CDDETest, da auch bei dieser Untersuchung keine Apoptose nachgewiesen werden konnte.

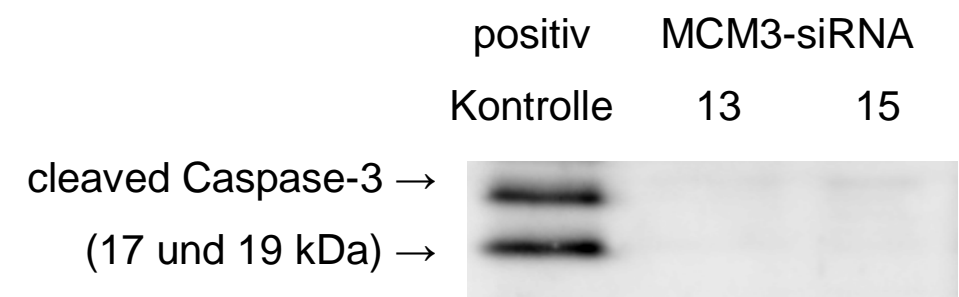

\begin{abstract}
Abbildung 27: Cleaved Caspase-3 Western Blot an Tag 8 nach Transfektion der U87MG-Zellen mit MCM3-siRNA 13 (10 nM) und MCM3-siRNA 15 (20 nM). Es können keine Caspase-Spaltprodukte nachgewiesen werden, somit ergab sich kein Hinweis auf eine Apoptoseinduktion bei den behandelten U87MG-Zellen
\end{abstract}

\subsection{Zellzyklusanalyse mittels FACS-Analyse mit Propidiumiodid}

Die FACS-Analyse wurde mit Propidiumiodid durchgeführt, da Nukleinsäure-bindende fluoreszierende Farbstoffe wie Propidiumiodid genutzt werden können, um den DNAGehalt in einer Zelle zu bestimmen. Daraus können Rückschlüsse auf die Zellzyklusphase gezogen werden, in der sich die Zellen befinden.

MCM-Proteine binden an Chromatin in der G1-Phase des Zellzyklus und bereiten dadurch die DNA für die Replikation bzw. den Eintritt der Zelle in die S-Phase vor. Im Verlauf der S-Phase dissoziieren die MCM-Proteine wieder von der DNA, sodass sichergestellt ist, dass die DNA pro Zellzyklus nur einmal repliziert werden kann. Im Weiteren sollte untersucht werden, inwieweit MCM3-siRNAs durch Suppression von MCM3 möglicherweise einen Zellzyklusarrest in der G0/G1-Phase oder auch einen mitotischen Arrest, erkennbar an einer Zunahme der Zellen in der G2/M-Phase, bewirken können. 
Zunächst konnte gezeigt werden, dass die Kontroll-siRNA keine Veränderungen im Zellzyklusverhalten im Vergleich zu den nur mit Liposomen behandelten U87MGZellen bewirkte (Abbildung 28a und 28b). Bei mit MCM3-siRNA 13-transfizierten Zellen fanden sich an Tag $420 \%$ mehr Zellen in der G1-Phase und jeweils ca. $10 \%$ weniger in S- und G2/M-Phase als bei den U87MG-Zellen, die mit Kontroll-siRNA behandelt wurden. An Tag 6 nach Transfektion zeigten sich bei den mit MCM3-siRNA 13transfizierten Zellen etwas mehr Zellen in den Phasen S und G2/M, wohingegen die Anzahl von Zellen in der G1-Phase im Vergleich zur Kontrolle um ca. $13 \%$ reduziert war (Abbildung 28a und 28b). Das Ergebnis zeigte, dass sich MCM3-siRNA 13transfizierte Zellen in einem G1-Arrest und einem mitotischen Arrest in der G2/MPhase befinden.

Das Zellzyklusverhalten von mit MCM3-siRNA 15-transfizierten U87MG-Zellen unterschied sich an Tag 4 nicht wesentlich von den Kontrollen. Eine Abnahme von Zellen in der G1-Phase bei gleichzeitiger Erhöhung des Anteils von Zellen in der G2/M-Phase im Vergleich zur Kontrolle an Tag 6 ließ sich geringfügig auch für mit MCM3-siRNA 15 transfizierte U87MG-Zellen zeigen (Abbildung 28a und 28b). Die durch MCM3siRNA 15 induzierten geringeren Effekte korrelierten ebenfalls mit den Ergebnissen der vorangegangenen Tests, in denen sich die MCM3-siRNA 15 als deutlich weniger effektiv als die MCM-siRNA 13 erwies. 


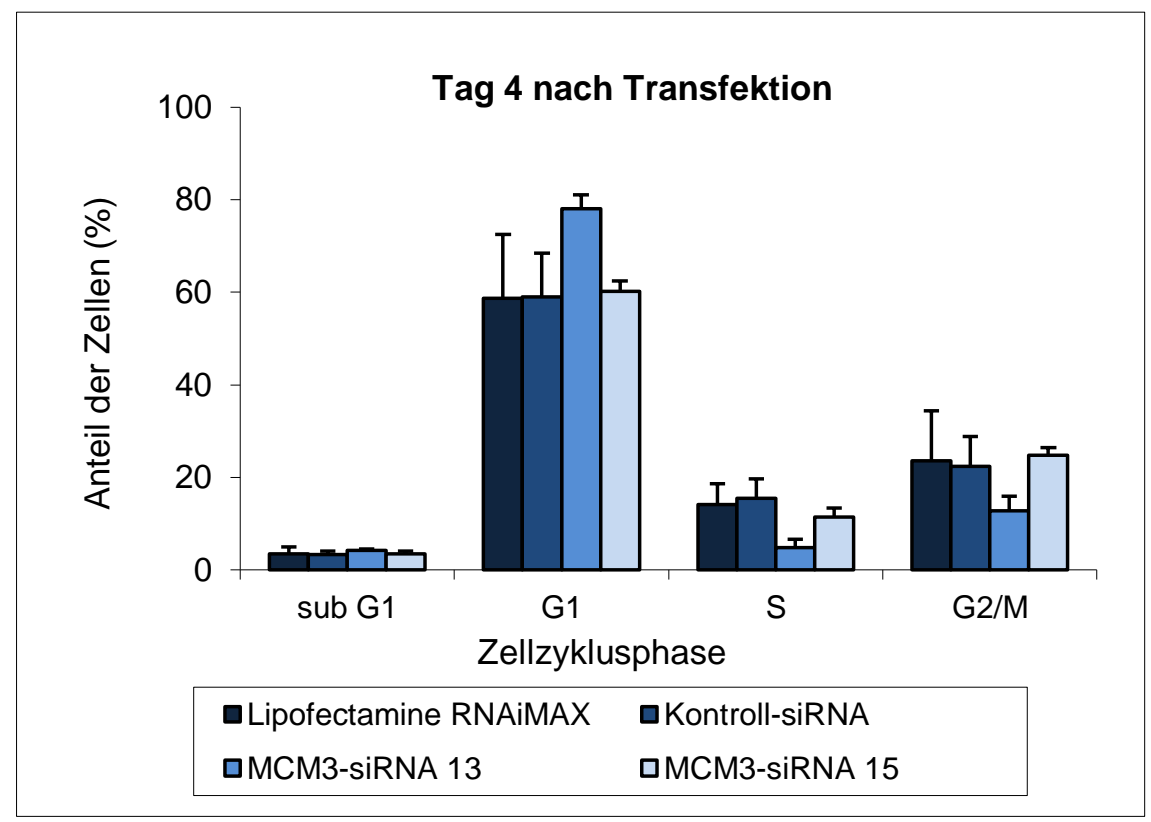

Abbildung 28a: FACS-Analyse zur Ermittlung der Zellzyklusphase der behandelten U87MG-Zellen mit Propidiumiodid an Tag 4 nach Transfektion. Eingesetzt wurden nur Lipofectamine RNAiMAX, Kontroll-siRNA (20 nM), MCM3-siRNA 13 (10 nM) und MCM3siRNA 15 (20 nM). Bei MCM3-siRNA 13-behandelten Zellen sind mehr Zellen in der G1-Phase nachzuweisen. y-Achse: Anteil der Zellen in \% der Kontrolle; $x$-Achse: Zellzyklusphase.

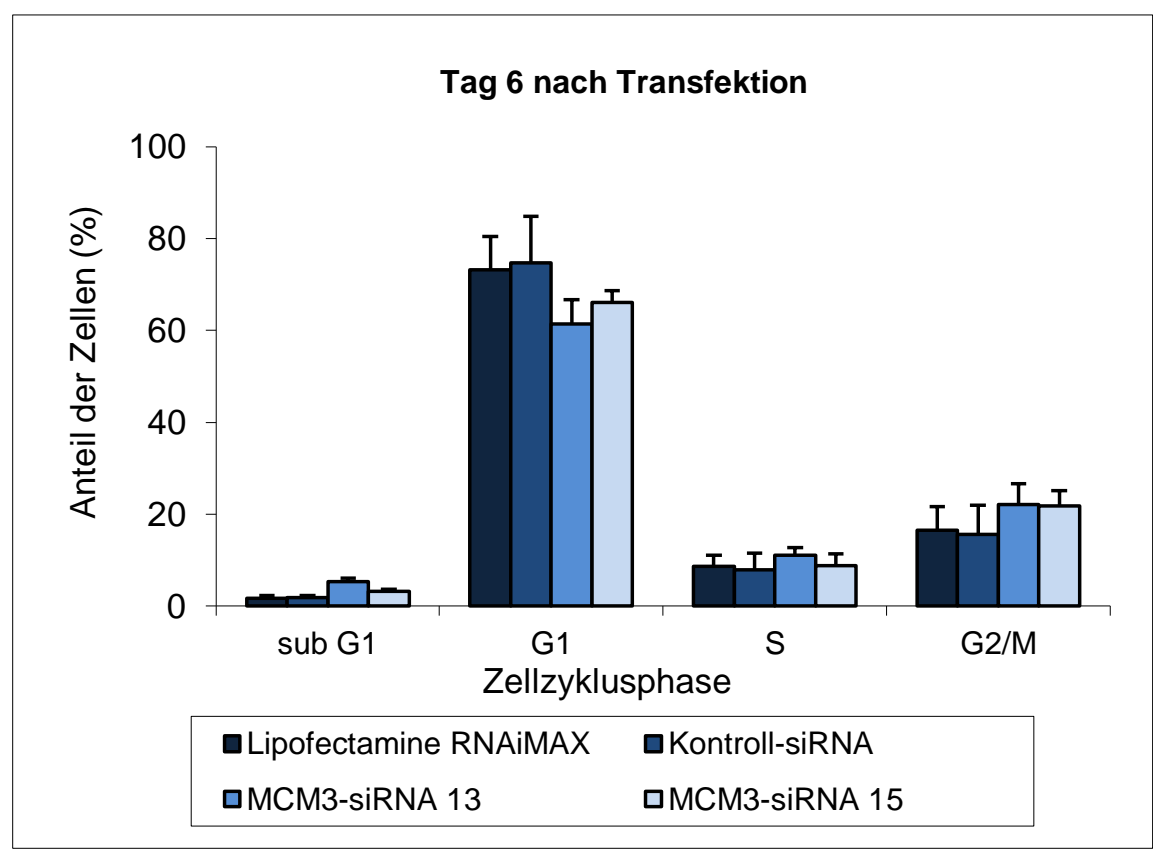

Abbildung 28b: FACS-Analyse zur Ermittlung der Zellzyklusphase der behandelten U87MG-Zellen mit Propidiumiodid an Tag 6 nach Transfektion. Eingesetzt wurden nur Lipofectamine RNAiMAX, Kontroll-siRNA (20 nM), MCM3-siRNA 13 (10 nM) und MCM3siRNA 15 (20 nM). y-Achse: Anteil der Zellen in \% der Kontrolle; $x$ Achse: Zellzyklusphase. 


\section{8 Überprüfung der MCM3-mRNA-Suppression nach Transfektion der U87MG-Zellen mit MCM3-siRNAs mittels real-time RT-PCR}

Wie bereits im Western Blot auf Proteinebene gezeigt, sind MCM3-siRNAs 13 und 15 sehr effektive Inhibitoren der MCM3-Expression. Im Weiteren wurde mittels real-time RT-PCR überprüft, ob und in welchem Ausmaß die Behandlung der U87MG-Zellen mit MCM3-siRNAs auch die MCM3-mRNA supprimiert.

Es zeigte sich eine deutliche Suppression der MCM3-mRNA nach Transfektion mit den MCM3-spezifischen siRNAs. Diese trat deutlich früher ein als die Inhibition der MCM3Proteinexpression (vergleiche Abbildungen 19 und 20 mit Abbildung 29). Bereits 24 Stunden nach MCM3-siRNA-Transfektion von U87MG-Zellen lag die MCM3-mRNA in mit MCM3-siRNA 13 und 15-transfizierten Zellen nur noch bei $13 \%$ bzw. $19 \%$ der Kontrolle (Abbildung 29).

Auffällig war, dass die Kinetik der mRNA-Suppression, die über 5 Tage durchgeführt wurde, von MCM3-siRNA 13- gegenüber MCM3-siRNA 15-behandelten Zellen sehr unterschiedlich ausfiel. Die MCM3-siRNA 15 bewirkt eine dauerhafte, starke Inhibition der MCM3-mRNA, die an Tag 5 nach Transfektion $96 \%$ betrug. Die höchste Suppression von MCM3-mRNA der MCM3-siRNA 15-behandelten Zellen wurde an Tag 4 mit 98,9\% gemessen.

Die mit MCM3-siRNA 13 behandelten Zellen zeigten eine maximale MCM3-mRNASuppression von $96 \%$ bereits an Tag 2. An den folgenden Tagen stieg die gemessene MCM3-mRNA-Konzentration im Vergleich zur Kontrolle allerdings wieder deutlich an. An Tag 3 zeigte sich ein sprunghafter Anstieg von MCM3-mRNA mit einer Suppression von nur $51 \%$ in der kinetischen Untersuchung. An Tag 4 und 5 stieg die Suppression von MCM3-mRNA wieder etwas an und lag bei $20 \%$ und $35 \%$ im Vergleich zur Kontrolle.

Eine hohe Suppression der MCM3-mRNA für beide eingesetzten MCM3-siRNAs korrelierte gut mit den anderen Versuchen. Allerdings fiel der Anstieg der MCM3mRNA für die MCM3-siRNA 13-behandelten U87MG-Zellen auf. 


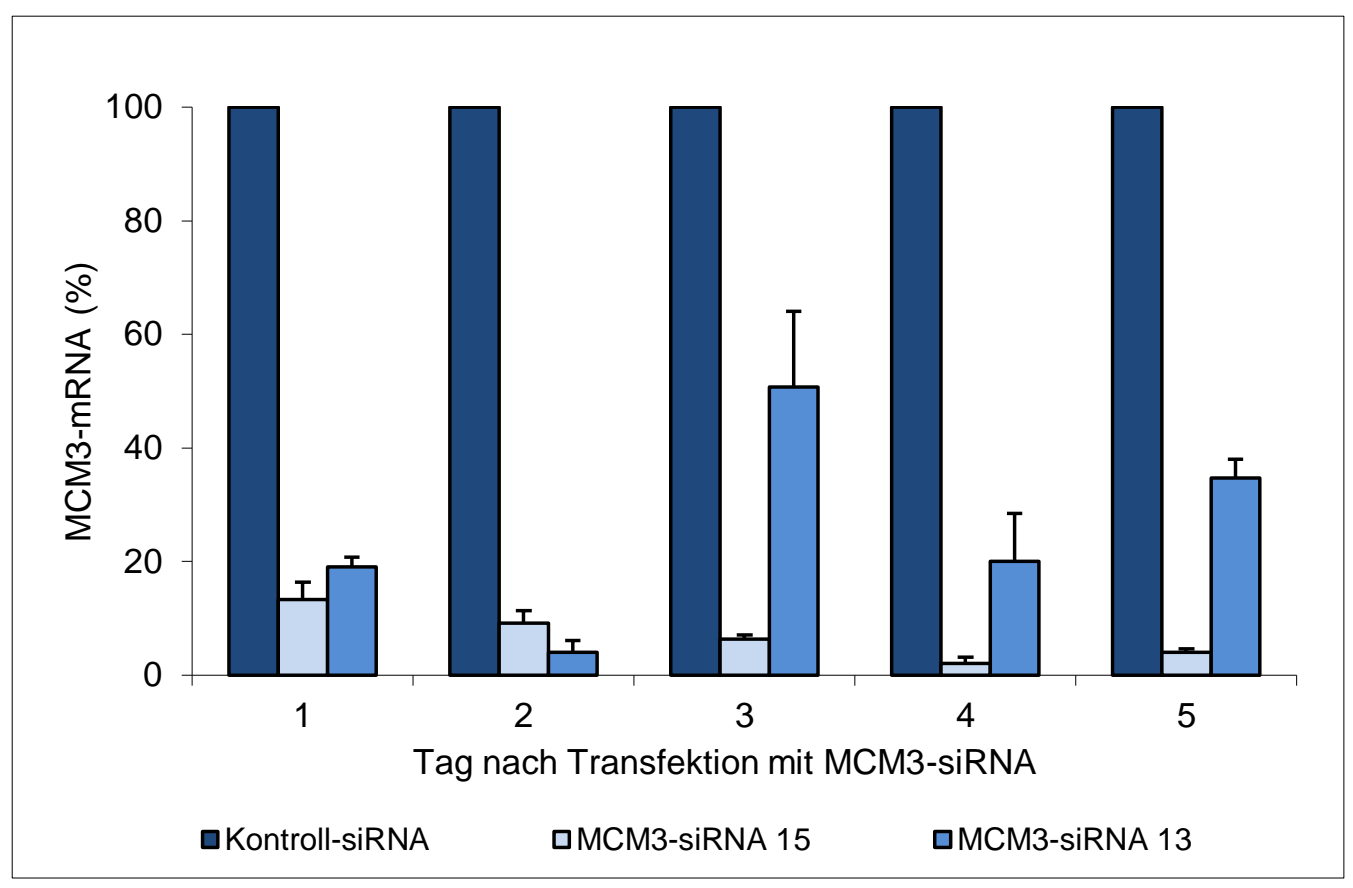

Abbildung 29: Quantitative real-time RT-PCR zur Bestimmung der MCM3-mRNASpiegel. Messung an Tag 1-5 nach Transfektion der U87MG-Zellen mit KontrollsiRNA (20 nM), MCM3-siRNA 15 (20 nM) und MCM3-siRNA 13 (10 nM). y-Achse: MCM3-mRNA in \% der Kontrolle; x-Achse: Tag nach Transfektion mit MCM3SiRNA.

\subsection{Langzeituntersuchung der Wirkung von MCM3-Suppression auf die Klonzahl mittels Clonogenic Assay}

Zur Untersuchung der Klonzahl nach Transfektion der U87MG-Zellen mit den MCM3siRNAs wurde ein Clonogenic Assay 14 Tage nach Transfektion durchgeführt. Hierbei konnte gezeigt werden, dass sich die bereits in vorausgegangenen Versuchen gezeigte verminderte Proliferation durch die Suppression von MCM3 durch MCM3siRNA auch im Langzeitversuch mit einer Dauer von 14 Tagen darstellen lässt.

Die mit MCM3-siRNA behandelten Zellen zeigten im Vergleich zur Kontrolle eine deutlich verminderte Zahl an Kolonien. Wie in den vorherigen Versuchen bereits dargestellt, zeigt die MCM3-siRNA 13 die höchste Wirksamkeit mit nur noch 7,7 \% der Kolonien im Vergleich zur Kontrolle. Bei der MCM3-siRNA 15 waren noch $37 \%$ der Kolonien im Vergleich zur Kontrolle zu sehen. (Abbildung 30). 


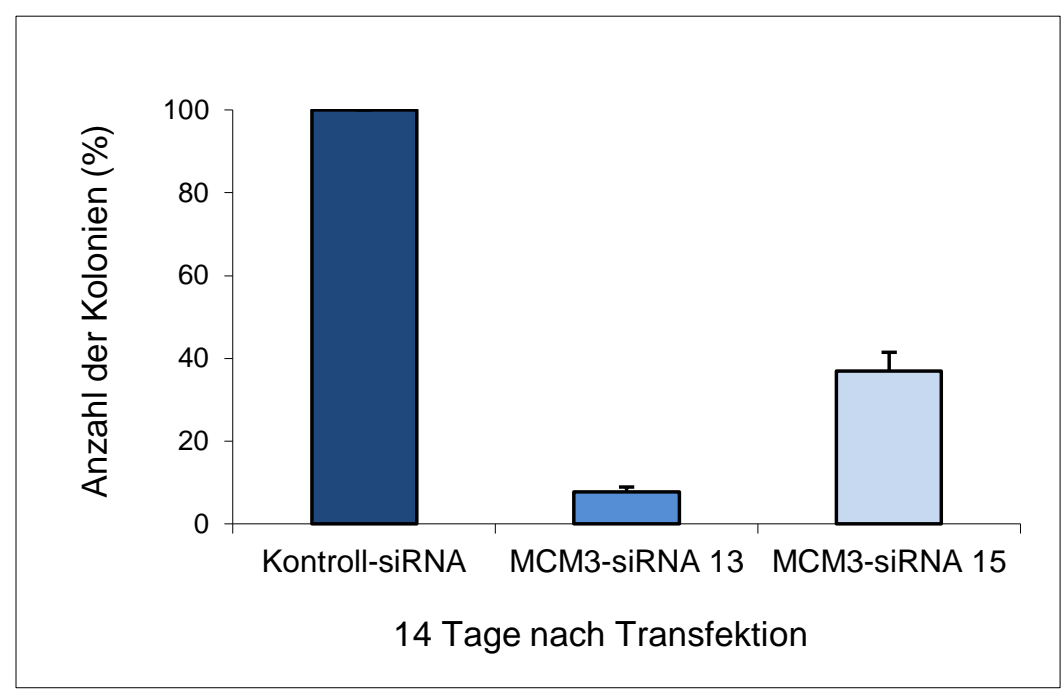

Abbildung 30: Clonogenic Assay zur Überprüfung des Langzeitüberlebens 14 Tage nach Transfektion der U87MGZellen mit Kontroll-siRNA (20nM), MCM3-siRNA 13 (10nM) und MCM3-siRNA 15 (20nM). Es zeigt sich eine deutlich verminderte Klonzahl. y-Achse: Anzahl der Kolonien in \% der Kontrolle; $x$ Achse: eingesetzte MCM3-siRNA. 


\section{Diskussion}

\subsection{Starke Suppression von MCM3 auf Proteinebene}

In dieser Arbeit wurde gezeigt, dass eine MCM3-Suppression in U87MG-Glioblastomzellen mittels RNA-Interferenz möglich ist. Die Quantifizierung der Western Blot-Ergebnisse zeigte eine sehr gute Korrelation zur geladenen Proteinmenge. Im Western Blot konnte für mehrere MCM3-siRNAs eine hohe Suppression von MCM3 gezeigt werden. Die beiden effektivsten MCM3-siRNAs waren MCM3-siRNA 13 und MCM3-siRNA 15, wobei die MCM3-siRNA 13 mit $93 \%$ Suppression von MCM3 den stärksten Effekt hatte. Die höchste Suppression von MCM3 bei MCM3-siRNA 15 lag bei $84,3 \%$. In den Kinetikuntersuchungen zeigte sich ein stetiger Anstieg der Suppression mit dem Maximum an Tag 4 (96 Stunden) nach Transfektion der U87MGZellen. Da die MCM3-siRNA-Wirkung über die Hemmung der mRNA-Trans-lation erfolgt, haben die MCM3-siRNAs keinen Einfluss auf zum Zeitpunkt der Transfektion bereits vorhandenes MCM3-Protein. Deshalb war dieses Ergebnis auch so zu erwarten.

\subsection{Verminderung der Stoffwechselaktivität und Proliferation durch MCM3-Suppression}

Die anschließenden Stoffwechselaktivitäts- und Proliferationstests zeigten, dass es durch die Antagonisierung von MCM3 zu einer verringerter Stoffwechselaktivität und Proliferation der U87MG-Zellen kommt. Sowohl im MTT-Test als auch im BrdU-Assay zeigte die MCM3-siRNA 13 die stärkste Suppression der Stoffwechselaktivität und der Proliferation. MCM3-siRNA 15 hatte im Vergleich zu MCM3-siRNA 13 eine etwas geringere Wirksamkeit. Im MTT-Test zeigten sich stetig abnehmende OD-Werte in den kinetischen Untersuchungen bis Tag 8. Die niedrigste Stoffwechselaktivität lag mit 21,4 \% an Tag 8 vor. Im BrdU-Assay zeigte sich für MCM3-siRNA 13 die niedrigste OD und somit die stärkste Verminderung der Proliferation $(13,1 \%)$ schon an Tag 4. Im Verlauf bis Tag 8 stieg diese dann wieder leicht auf 21,6\% an.

Bei MCM3-siRNA 15 zeigte sich im MTT-Test an Tag 8 ein leichter Anstieg der Stoffwechselaktivität. Die niedrigste Stoffwechselaktivität mit 65,4 \% lag an Tag 6 vor. Im BrdU-Assay lag die Reduktion der Proliferation von Tag 4 bis Tag 8 stabil bei ca. $65 \%$. 
Diese Effekte sind durch eine Vermehrung der nicht transfizierten Zellen zu erklären. Da die nicht transfizierten Zellen sich weiter teilen, nehmen diese im Verhältnis zu den transfizierten Zellen relativ gesehen zu. Die nicht transfizierten Zellen sind aber im Gegensatz zu den transfizierten U87MG-Zellen aufgrund fehlender MCM3Suppression nicht in ihrer Stoffwechselaktivität und Proliferationsfähigkeit eingeschränkt. Dies erklärt die ansteigenden OD-Werte in den kinetischen Untersuchungen. Des Weiteren ist ein intrazellulärer siRNA-Abbau sowie eine intrazelluläre Verdünnung der siRNAs wahrscheinlich. Dies führt innerhalb dieser Zellpopulation zu einem Anstieg sich teilender Zellen ohne MCM3-Suppression, was ebenfalls zu erhöhter Stoffwechselaktivität bzw. Proliferationsfähigkeit im Verlauf der kinetischen Untersuchungen führt. Die Stoffwechselaktivitäts- und Proliferationstests wurden zuletzt an Tag 8 gemessen, da die mit Kontroll-siRNA transfizierten Zellen dann zu konfluent waren, um weitere Messzeitpunkte einzuschließen.

In allen durchgeführten Untersuchungen zeigte die MCM3-siRNA 13 die höchste Wirksamkeit und die deutlichste Suppression.

Die Untersuchungen mittels MTT-Test und BrdU-Test zeigten Ergebnisse, die mit den Ergebnissen der Western Blots sehr gut korrelierten, da die höhere Suppression von MCM3 auf Proteinebene durch MCM3-siRNA 13 im Vergleich zu MCM3-siRNA 15 auch die stärkere Inhibition der Stoffwechselaktivität und Proliferation der U87MGZellen zeigte.

\subsection{MCM3-Suppression bewirkt einen Proliferationsstopp mit Zell- zyklusarrest, aber keine Apoptose}

Auch bei der Trypanblau-Färbung zeigte sich eine deutlich verminderte Zellzahl, was durch einen Proliferationsstopp oder auch durch den Untergang von Zellen zu erklären war. Die Zellzahl der MCM3-siRNA 13-behandelten Zellen lag bei nur 8,3 \% im Vergleich zur Kontrollgruppe. Bei MCM3-siRNA 15 waren es 42,6\%. Auch bei der Trypanblau-Färbung korrelierte die deutlich höhere Effektivität von MCM3-siRNA 13 mit den zuvor durchgeführten Versuchen.

Es zeigten sich allerdings nur sehr wenig blau angefärbte Zellen bei der Zellzählung. Da tote Zellen durch Trypanblau angefärbt werden, war von einem Proliferations-stopp und nicht von einer Apoptoseinduktion auszugehen. Dieses wurde durch nachfolgende Untersuchungen wie CDDE-Test und Caspase-3-Western Blot weiter belegt. 
Im CDDE-Test konnte im Vergleich zur Kontrolle weder bei MCM3-siRNA 13 noch bei MCM3-siRNA 15 eine erhöhte Apoptoserate festgestellt werden. Im Caspase-3Western Blot ergaben sich nach der Behandlung der U87MG-Zellen mit den MCM3siRNAs ebenfalls keine Hinweise auf eine Induktion von Apoptose, da keine CaspaseSpaltprodukte nachgewiesen wurden.

Zum Nachweis eines Proliferationsstopps wurde nachfolgend eine Zellzyklusanalyse mittels FACS-Analyse mit Propidiumiodid durchgeführt. In der Zellzyklusanalyse bestätigte sich, was die bisherigen Ergebnisse vermuten ließen. Die mit MCM3siRNA 13 behandelten U87MG-Zellen zeigten einen G0/G1-Arrest und im Verlauf einen mitotischen Arrest in der G2/M-Phase. Es waren $20 \%$ mehr Zellen in der G1Phase und jeweils $10 \%$ weniger in S- und G2/M-Phase als bei den U87MG-Zellen, die mit Kontroll-siRNA behandelt wurden. Die Ergebnisse der FACS-Analyse für die mit MCM3-siRNA 13 behandelten Zellen passen zu den Vorversuchen. Für MCM3siRNA 15-transfizierte U87MG-Zellen konnte eine Abnahme von Zellen in der G0/G1Phase bei gleichzeitiger Erhöhung des Anteils von Zellen in der G2/M-Phase an Tag 6 in geringem Ausmaß ebenfalls gezeigt werden, allerdings kein G1-Arrest wie bei den mit MCM3-siRNA 13 behandelten Zellen. Unter Berücksichtigung von Publikationen, die den Einfluss verschiedener Chemotherapeutika inklusive small molecules auf den Zellzyklus in verschiedenen Krebszelllinien untersuchten (Marcus et al. 2005), sollte der Zeitpunkt der FACS-Analyse für weitere Experimente variiert werden.

Da die Behandlung der U87MG-Zellen mittels MCM3-siRNA keine Effekte auf bereits vorhandenes MCM3 hat, wurden die Untersuchungszeitpunkte in dieser Arbeit mit Tag 4 und Tag 6 unter der Annahme gewählt, dass sich die Suppression von MCM3 erst einstellen muss, damit Veränderungen am Zellzyklus nachgewiesen werden können. Demzufolge wurden die Untersuchungen zum Zeitpunkt der maximalen MCM3Suppression an Tag 4 nach Transfektion durchgeführt.

Aufgrund der Ergebnisse von Marcus et al. sollten aber auch sicher Zeitpunkte früher als 4 Tage nach siRNA-Transfektion analysiert werden (z.B. Zeitpunkt 24, 48 und 72 Stunden nach siRNA-Transfektion). Wie anhand der Ergebnisse der Western Blots dargestellt, waren die MCM3-Konzentrationen bereits nach 48 Stunden um $32 \%$ und nach 72 Stunden um über $90 \%$ im Vergleich zur Kontrolle reduziert, so dass zu diesem Zeitpunkt auch schon Veränderungen des Zellzyklusverhaltens vorliegen könnten. Deshalb sollte in weiteren Experimenten überprüft werden, ob sich an früheren Zeitpunkten nach Transfektion schon Effekte im Sinne von G0/G1- oder G2/M- 
Arresten der U87MG-Zellen darstellen lassen. Vielleicht ist unter diesen Versuchsbedingungen ein noch deutlicherer Effekt der MCM3-siRNAs auf den Zellzyklus darzustellen als in den bisherigen ab Tag 4 durchgeführten Untersuchungen.

Im Clonogenic Assay konnte gezeigt werden, dass sich die verminderte Proliferation durch die Suppression von MCM3 durch MCM3-siRNAs auch im Langzeitversuch mit einer Dauer von 14 Tagen darstellen lässt. Die MCM3-siRNA 13 zeigte auch im Clonogenic Assay die höchste Effektivität. Bei MCM3-siRNA 13-behandelten U87MGZellen waren nach 14 Tagen nur 7,7\% der Kolonien im Vergleich zur Kontrolle gewachsen. Bei der MCM3-siRNA 15 konnten noch $37 \%$ der Kolonien im Vergleich zur Kontrolle dokumentiert werden. Die Ergebnisse des Langzeitversuchs korrelierten sehr gut mit den Ergebnissen des MTT-Tests, des BrdU-Assays und der TrypanblauFärbung, da sich eine deutlich verminderte Proliferation der behandelten Zellen zeigte. Die größere Effektivität von MCM3-siRNA 13 im Vergleich zur MCM3-siRNA 15, die in den anderen Versuchen zu sehen war, bestätigte sich im Clonogenic Assay ebenfalls. $\mathrm{Da}$ MCM3 im Vergleich zu anderen MCM-Proteinen in Tumorzellen stark überexprimiert ist, kann aufgrund der Versuchsergebnisse angenommen werden, dass erst ab einer Suppression des MCM3-Proteinniveaus von $>90 \%$ wirklich effektive hemmende Effekte auf Stoffwechselaktivität und Proliferation von Glio-blastomzellen erzielt werden können.

\subsection{Bestimmung der MCM3-mRNA-Spiegel in der kinetischen Untersuchung von MCM3-siRNA-behandelten Zellen mittels real-time RT-PCR.}

Die Untersuchung der MCM3-Suppression auf mRNA Ebene stehen etwas im Kontrast zu den anderen Ergebnissen, bei denen MCM3-siRNA 13 stets die wirksamste siRNA war. Während in allen durchgeführten funktionellen Assays wie auch im Western Blot die MCM3-siRNA 13 den höchsten Effekt hatte, stellte sich dies in der mRNA-Analyse anders dar. Die Suppression von MCM3-mRNA an Tag 2 nach Transfektion der U87MG-Zellen war mit $96 \%$ Hemmung für MCM3-siRNA 13 und $90 \%$ für MCM3siRNA 15 im Bereich der Erwartungen. Ab Tag 3 stieg die Konzentration der mRNA im Vergleich zur Kontrolle in den mit MCM3-siRNA 13 behandelten Proben wieder bis auf $49 \%$ im Vergleich zur Kontrolle an und betrug am letzten Tag der Messung $35 \%$. Im Vergleich dazu blieb die Suppression von MCM3-mRNA in den mit MCM3-siRNA 15 
behandelten U87MG-Zellen auf einem unverändert hohen Niveau von über $90 \%$. Am letzten Tag zeigte sich bei den U87MG-Zellen, die mit MCM3-siRNA 15 behandelt wurden, eine Suppression von $96 \%$. Es wäre aufgrund der vorangegangenen Versuche ein deutlich höherer Effekt für die MCM3-siRNA 13 und nicht für MCM3siRNA 15 zu erwarten gewesen. Anders betrachtet wäre aufgrund der real-time RTPCR-Ergebnisse ein deutlich stärkerer Effekt auf Proteinebene und in den funktionellen Assays für die MCM3-siRNA 15 zu erwarten gewesen. Da beide siRNAs an guide- und passenger-Strang modifiziert und in sehr niedrigen Konzentrationen eingesetzt wurden, erscheinen Off-Target-Effekte als Erklärung für die dargestellten Effekte eher unwahrscheinlich. Auch weil anhand von Western Blot und real-time RTPCR gezeigt wurde, dass die Expression von housekeeping-Genen nicht beeinflusst wurde.

Ein möglicher Erklärungsansatz ist, dass die endogenen MCM3-mRNA-Konzentrationen im Gegensatz zu den MCM3-Protein-Spiegeln in Abhängigkeit von der Zellzyklusphase sehr stark schwanken und am Ende der G1-Phase besonders hoch sind (Musahl et al. 1998). Da bei den mit MCM3-siRNA 13 behandelten Zellen ein hoher Teil der U87MG-Zellen in einen G1-Arrest tritt, könnte somit auch erklärt werden, wieso die Konzentration von MCM3-mRNA in den Zellen wieder zunimmt und es bei MCM3siRNA 15 nicht dazu kommt. Deshalb sollte eine erneute Wiederholung der Versuchsreihe mit synchronisierten U87MG-Zellen durchgeführt werden, um einer Verschleierung von MCM3-siRNA-Effekten durch verschiedene Zellzyklusstadien der Zellen entgegenzuwirken, da sich bei synchronisierten Zellpopulationen alle Zellen in der gleichen Zellzyklusphase befinden. Synchronisierte Zellen sollten eine zuverlässigere vergleichende Beurteilung der durch die verschiedenen MCM3-siRNAs ausgelösten Effekte bezüglich des Zellzyklus erlauben.

\subsection{MCM3 ist ein geeignetes Angriffsziel in der Glioblastomtherapie}

Aufgrund ihres schnellen und infiltrativen Wachstums beträgt die mediane Überlebenszeit von Patienten mit einem Glioblastom nur wenige Monate, die auch mit der aktuellen Therapie nur etwas gesteigert werden kann (Claes et al. 2007). Die postoperative Tumormasse hat eine große prognostische Aussagekraft für die mittlere Überlebenszeit der Patienten (Stummer et. al 2006). Wie in dieser Arbeit dargestellt, führt die Behandlung von U87MG-Zellen mittels MCM3-siRNA zu einem Proliferationsstopp. Eine Therapie, die im Anschluss an die operative Tumorreduktion 
das Wachstum hemmen würde, könnte eine erneute Ausdehnung des Tumors oder auch die Entstehung von Rezidiven deutlich verlangsamen. Dieses würde für Patienten mit einem Glioblastom keine Heilung bedeuten, aber könnte zu einer deutlich verlängerten Überlebenszeit führen. Des Weiteren könnten tödliche Komplikationen wie Hirndrucksymptomatik mit neurologischen Ausfallserschei-nungen aufgrund der Tumorausdehnung nicht verhindert, aber doch verzögert werden und so die Lebensqualität der Patienten deutlich verbessert werden.

Dafür ist es wichtig, die in dieser Arbeit in vitro gezeigten Ergebnisse zuerst auch in vivo im Mausmodell zu überprüfen. Es gibt verschiedene Möglichkeiten siRNAs in vivo anzuwenden. Eine Möglichkeit ist die Verwendung von viralen Vektoren, z.B. adenoassoziierten Viren, die einen effizienten Transport in Zielgewebe ermöglichen (Shim und Kwon 2010, Wu et al. 2006).

Weiterhin werden kationische Lipide wie Lipofectamine® 2000 für die direkte intravenöse Anwendung verwendet (Kamlah et al. 2009). Neuere Entwicklungen werden als noch effektiver beschrieben, wie z.B. Invivofectamine ${ }^{\circledR} 2.0$ von Lifetechnologies.

Die neusten Entwicklungen auf dem Gebiet der Nanotechnologie sind ebenfalls vielversprechend (lyer et al. 2014, Shi et al. 2014). Eine erfolgreiche In-VivoAnwendung von an Nanopartikel gekoppleten siRNAs im Mausmodell wurde bereits mehrfach publiziert. So konnte z.B. nach Behandlung mittels an Nanopartikel gekoppelter siRNAs ein vermindertes Wachstum von Kopf-Hals-Karzinomen bei Mäusen gezeigt werden (Rahman et al. 2012).

Für eine Therapie am Menschen müssten geeignete Transportwege für die siRNA in die spezifischen Zielgewebe und in der Glioblastomzelle etabliert werden. Die Entwicklung solcher Transportsysteme ist aktueller Gegenstand der Forschung. 


\section{Zusammenfassung}

In dieser Arbeit wurde die spezifische Suppression von MCM3, das in Glioblastomzellen vermehrt exprimiert wird, in humanen Glioblastomzellen (U87MG) mittels RNAi und deren Auswirkungen auf Stoffwechselaktivität, Zellvitalität, Proliferation, Zellzyklus und Apoptose untersucht. Es konnte gezeigt werden, dass spezifische MCM3-siRNAs einen hemmenden Effekt auf die Proliferation humaner Glioblastomzellen ausüben können.

Es wurden in Vorversuchen fünf MCM3-siRNAs getestet, wobei alle eine Suppression von MCM3 auf Proteinebene zeigten. Die weiteren Analysen wurden mit den beiden effektivsten MCM3-siRNAs (MCM3-siRNA 13 und MCM3-siRNA 15) fortgesetzt. Die MCM3-siRNA 13 zeigte auf Proteinebene im Western Blot bei einer niedrigen Konzentration von $10 \mathrm{nM}$ eine MCM3-Suppression von >90\%, MCM3-siRNA 15 immerhin eine Inhibition von 84 \%. In funktionellen Analysen zur Stoffwechselaktivität und Proliferation wie MTT-Test, BrdU-Assay und Trypanblau-Färbung konnte eine verminderte Stoffwechselaktivität und ein Proliferationsstopp der behandelten U87MG-Zellen nachgewiesen werden. Dieser zeigte sich in einem G0/G1- sowie G2/M-Arrest der behandelten Zellen in der FACS-Analyse mit Propidiumiodid. Hinweise für eine Einleitung der Apoptose von U87MG-Zellen durch Behandlung mit MCM3-siRNAs ergaben sich nicht. Die effektivste der beiden eingesetzten MCM3siRNAs war sowohl im Western Blot als auch in den funktionellen Assays die MCM3siRNA 13. Sie zeigte sowohl auf Proteinebene die höchste Suppressionsrate als auch die niedrigste Stoffwechselaktivität und Proliferation in den funktionellen Assays. In der real-time RT-PCR zeigte sich ebenfalls eine hohe Suppression von MCM3-mRNA. Hier konnte allerdings für die sonst im Vergleich zu MCM3-siRNA 13 weniger effektive MCM3-siRNA 15 die höchste Suppression von MCM3-mRNA dargestellt werden. Es gibt Erklärungen, warum die MCM3-siRNA 13 auf mRNA-Ebene weniger effektiv als MCM3-siRNA 15 war, aber dieses muss in weiteren Versuchen noch genauer analysiert werden.

Der gezeigte Proliferationsstopp der Glioblastomzellen könnte bei einer möglichen therapeutischen siRNA-Behandlung eine Ausdehnung des Tumors oder die Entstehung von Rezidiven verlangsamen. Für die Patienten wäre dies keine Heilung, es könnte aber zu einer verlängerten Überlebenszeit mit einer höheren Lebensqualität führen. 


\section{Literaturverzeichnis}

1. Aparicio OM, Weinstein DM, Bell SP (1997): Components and dynamics of DNA replication complexes in S. cerevisiae: redistribution of MCM proteins and Cdc45p during $S$ phase. Cell 91, 59-69

2. Ashkavandi ZJ, Najvani AD, Tadbir AA, Pardis S, Ranjbar MA, Ashraf MJ (2013): MCM3 as a novel diagnostic marker in benign and malignant salivary gland tumors. Asian Pac J Cancer Prev 14, 3479-3482

3. Bernstein E, Caudy AA, Hammond SM, Hannon GJ (2001): Role for a bidentate ribonuclease in the initiation step of RNA interference. Nature $\underline{409}, 363-366$

4. Berridge MV, Herst PM, Tan AS (2005): Tetrazolium dyes as tools in cell biology: new insights into their cellular reduction. Biotechnol Annu Rev $\underline{11}, 127-$ 152

5. Bressler H: Die Krankheiten des Kopfes und der Sinnesorgane. Verlag der Voss'schen Buchhandlung, Berlin 1839

6. Chapman EJ, Carrington JC (2007): Specialization and evolution of endogenous small RNA pathways. Nat Rev Genet $\underline{8}$, 884-896

7. Claes A, Idema AJ, Wesseling P (2007): Diffuse glioma growth: a guerilla war. Acta Neuropathol 114, 443-458

8. Davis FG, McCarthy BJ, Freels S, Kupelian V, Bondy ML (1999): The conditional probability of survival of patients with primary malignant brain tumors: surveillance, epidemiology, and end results (SEER) data. Cancer $\underline{85}$, 485-491

9. Facoetti A, Ranza E, Benericetti E, Ceroni M, Tedeschi F, Nano R (2006): Minichromosome maintenance protein 7: a reliable tool for glioblastoma proliferation index. Anticancer Res $\underline{26}, 1071-1075$

10. Fire A, Albertson D, Harrison SW, Moerman DG (1991): Production of antisense RNA leads to effective and specific inhibition of gene expression in $\mathrm{C}$. elegans muscle. Development $\underline{113}, 503-514$

11. Fire A, Xu S, Montgomery MK, Kostas SA, Driver SE, Mello CC (1998): Potent and specific genetic interference by double-stranded RNA in Caenorhabditis elegans. Nature $\underline{391}, 806-811$

12. Gonzalez MA, Pinder SE, Callagy G, Vowler SL, Morris LS, Bird K, Bell JA, Laskey RA, Coleman N (2003): Minichromosome maintenance protein 2 is a 
strong independent prognostic marker in breast cancer. J Clin Oncol 21, 43064313

13. Hammond SM, Bernstein E, Beach D, Hannon GJ (2000): An RNA-directed nuclease mediates post-transcriptional gene silencing in Drosophila cells. Nature $\underline{404}$, 293-296

14. Harmalkar MN, Shirsat NV (2006): Staurosporine-induced growth inhibition of glioma cells is accompanied by altered expression of cyclins, CDKs and CDK Inhibitors. Neurochem Res $\underline{31}$, 685-692

15. Hegi ME, Diserens AC, Gorlia T, Hamou MF, de Tribolet N, Weller M, Kros JM, Hainfellner JA, Mason W, Mariani L (2005): MGMT gene silencing and benefit from temozolomide in Glioblastom. N Engl J Med 352, 997-1003

16. Hendrickson M, Madine M, Dalton S, Gautier J (1996): Phosphorylation of MCM4 by cdc2 protein kinase inhibits the activity of the minichromosome maintenance complex. Proc Natl Acad Sci U S A 93, 12223-12228

17. Herzenberg LA, Sweet RG, Herzenberg LA (1976): Fluorescence-activated cell sorting. Sci Am 234, 108-117

18. Hutvagner G, Zamore PD (2002): RNAi: nature abhors a double-strand. Curr Opin Genet Dev 12, 225-232

19. Hutvagner G, Simard MJ (2008): Argonaute proteins: key players in RNA silencing. Nat Rev Mol Cell Biol $\underline{9}, 22-32$

20. Igci YZ, Erkilic S, Igci M, Arslan A (2014): MCM3 Protein Expression in Follicular and Classical Variants of Papillary Thyroid Carcinoma. Pathol Oncol Res $\underline{20}$, 87-91

21. Iyer A, Duan Z, Amiji M (2014): Nano-Delivery Systems for Nucleic Acid Therapeutics in Drug Resistant Tumors. Mol Pharm, [Epub ahead of print]

22. Izant JG, Weintraub H (1984): Inhibition of thymidine kinase gene expression by anti-sense RNA: a molecular approach to genetic analysis. Cell $\underline{36}, 1007-$ 1015

23. Kamlah F, Eul BG, Li S, Lang N, Marsh LM, Seeger W, Grimminger F, Rose F, Hänze J (2009): Intravenous injection of siRNA directed against hypoxiainducible factors prolongs survival in a Lewis lung carcinoma cancer model. Cancer Gene Ther $\underline{16}$, 195-205

24. Kearsey SE, Labib K (1998): MCM proteins: evolution, properties, and role in DNA replication. Biochim Biophys Acta 1398, 113-136 
25. Kleihues P, Louis DN, Scheithauer BW, Rorke LB, Reifenberger G, Burger PC, Cavenee WK (2002): The WHO classification of tumors of the nervous system. J Neuropathol Exp Neurol 61, 215-225

26. Korkolopoulou P, Givalos N, Saetta A, Goudopoulou A, Gakiopoulou H, Thymara I, Thomas-Tsagli E, Patsouris E (2005): Minichromosome maintenance proteins 2 and 5 expression in muscle-invasive urothelial cancer: a multivariate survival study including proliferation markers and cell cycle regulators. Hum Pathol $\underline{36}$, 899-907

27. Kubota Y, Mimura S, Nishimoto S, Masuda T, Nojima H, Takisawa H (1997): Licensing of DNA replication by a multi-protein complex of MCM/P1 proteins in Xenopus eggs. EMBO J 16, 3320-3331

28. Laperriere N, Zuraw L, Cairncross G; Cancer Care Ontario Practice Guidelines Initiative Neuro-Oncology Disease Site Group (2002): Radiotherapy for newly diagnosed malignant glioma in adults: a systematic review. Radiother Oncol $\underline{64}$, 259-273

29. Lau KM, Chan QK, Pang JC, Li KK, Yeung WW, Chung NY, Lui PC, Tam YS, Li HM, Zhou L, Wang Y, Mao Y, Ng HK (2010): Minichromosome maintenance proteins 2, 3 and 7 in medulloblastoma: overexpression and involvement in regulation of cell migration and invasion. Oncogene $\underline{29}, 5475-5489$

30. Lei M, Kawasaki Y, Tye BK (1996): Physical interactions among Mcm proteins and effects of Mcm dosage on DNA replication in Saccharomyces cerevisiae. Mol Cell Biol 16, 5081-5090

31. Lei M, Tye BK (2001): Initiating DNA synthesis: from recruiting to activating the MCM complex. J Cell Sci 114,1447-1454

32. Louis DN, Ohgaki H, Wiestler OD, Cavenee WK, Burger PC, Jouvet A, Scheithauer BW, Kleihues P (2007): The 2007 WHO classification of tumours of the central nervous system. Acta Neuropathol 114, 97-109

33. Lowry OH, Rosebrough NJ, Farr AL, Randall RJ (1951): Protein measurement with the Folin phenol reagent. J Biol Chem 193, 265-275

34. Maine GT, Sinha P, Tye BK (1984): Mutants of S. cerevisiae defective in the maintenance of minichromosomes. Genetics 106, 365-385

35. Maiorano D, Lutzmann M, Méchali M (2006): MCM proteins and DNA replication. Curr Opin Cell Biol $\underline{18}, 130-136$ 
36. Marcus Al, Peters U, Thomas SL, Garrett S, Zelnak A, Kapoor TM, Giannakakou P (2005): Mitotic kinesin inhibitors induce mitotic arrest and cell death in Taxol-resistant and -sensitive cancer cells. J Biol Chem 280, 1156911577

37. Masai H, Matsui E, You Z, Ishimi Y, Tamai K, Arai K (2000): Human Cdc7related kinase complex. In vitro phosphorylation of MCM by concerted actions of Cdks and Cdc7 and that of a criticial threonine residue of Cdc7 by Cdks. J Biol Chem 275, 29042-29052

38. Minniti G, Muni R, Lanzetta G, Marchetti P, Enrici RM (2009): Chemotherapy for glioblastoma: current treatment and future perspectives for cytotoxic and targeted agents. Anticancer Res $\underline{29}, 5171-5184$

39. Mosmann T (1983): Rapid colorimetric assay for cellular growth and survival: application to proliferation and cytotoxicity assays. J Immunol Methods $\underline{65}, 55-$ 63

40. Musahl C, Holthoff HP, Lesch R, Knippers R (1998): Stability of the replicative Mcm3 protein in proliferating and differentiating human cells. Exp Cell Res $\underline{241}$, 260-264

41. Nakada M, Nakada S, Demuth T, Tran NL, Hoelzinger DB, Berens ME (2007): Molecular targets of glioma invasion. Cell Mol Life Sci 64, 458-478

42. Nicoletti I, Migliorati G, Pagliacci MC, Grignani F, Riccardi C (1991): A rapid and simple method for measuring thymocyte apoptosis by propidium iodide staining and flow cytometry. J Immunol Methods 139, 271-279

43. Ohgaki H, Kleihues P (2005 a): Epidemiology and etiology of gliomas. Acta Neuropathol 109, 93-108

44. Ohgaki H, Kleihues $P$ (2005 b): Population-based studies on incidence, survival rates, and genetic alterations in astrocytic and oligodendroglial gliomas. $J$ Neuropathol Exp Neurol 64, 479-489

45. Porstmann T, Ternynck T, Avrameas S (1985): Quantitation of 5-bromo-2deoxyuridine incorporation into DNA: an enzyme immunoassay for the assessment of the lymphoid cell proliferative response. $\mathrm{J}$ Immunol Methods $\underline{82}$, 169-179

46. Prokhorova TA, Blow JJ (2000): Sequential MCM/P1 subcomplex assembly is required to form a heterohexamer with replication licensing activity. J Biol Chem $\underline{275}, 2491-2498$ 
47. Rahman MA, Amin AR, Wang X, Zuckerman JE, Choi CH, Zhou B, Wang D, Nannapaneni S, Koenig L, Chen Z (2012): Systemic delivery of siRNA nanoparticles targeting RRM2 suppresses head and neck tumor growth. J Control Release 159, 384-92

48. Riemenschneider MJ, Reifenberger G (2009): Molecular neuropathology of gliomas. Int J Mol Sci $\underline{10}, 184-212$

49. Rutz S, Scheffold A (2004): Towards in vivo application of RNA interference new toys, old problems. Arthritis Res Ther $\underline{6}, 78-85$

50. Schneider T, Mawrin C, Scherlach C, Skalej M, Firsching R (2010): Die Gliome des Erwachsenen. Dtsch Arztebl Int 107, 799-808

51. Schories B, Engel K, Dörken B, Gossen M, Bommert K (2004): Characterization of apoptosis-induced Mcm3 and Cdc6 cleavage reveals a proapoptotic effect for one Mcm3 fragment. Cell Death Differ 11, 940-942

52. Schrader C, Janssen D, Klapper W, Siebmann JU, Meusers P, Brittinger G, Kneba M, Tiemann M, Parwaresch R (2005): Minichromosome maintenance protein 6, a proliferation marker superior to Ki-67 and independent predictor of survival in patients with mantle cell lymphoma. Br J Cancer 93, 939-945

53. Schwacha A, Bell SP (2001): Interactions between two catalytically distinct MCM subgroups are essential for coordinated ATP hydrolysis and DNA replication. Mol Cell $\underline{8}, 1093-1104$

54. Shi J, Xu Y, Xu X, Zhu X, Pridgen E, Wu J, Votruba AR, Archana S, Zetter BR, Farokhzad OC (2014): Hybrid lipid-polymer nanoparticles for sustained siRNA delivery and gene silencing. Nanomedicine, [Epub ahead of print]

55. Shim MS, Kwon YJ (2010): Efficient and targeted delivery of siRNA in vivo. FEBS J $\underline{277}, 4814-27$

56. Soeling A, Sackewitz M, Volkmar M, Schaarschmidt D, Jacob R, Holzhausen HJ, Rainov NG (2005): Minichromosome maintenance protein 3 elicits a cancerrestricted immune response in patients with brain malignancies and is a strong independent predictor of survival in patients with anaplastic astrocytoma. Clin Cancer Res 11, 249-258

57. Stummer W, Pichlmeier U, Meinel T, Wiestler OD, Zanella F, Reulen HJ, ALAGlioma Study Group (2006): Fluorescence-guided surgery with 5-aminolevulinic acid for resection of malignant glioma: a randomised controlled multicentre phase III trial. Lancet Oncol $\underline{7}, 392-401$ 
58. Stupp R, Hottinger AF (2008): Management of malignant glioma - quo vadis? Onkologie 31, 300-302

59. Stupp R, Mason WP, van den Bent MJ, Weller M, Fisher B, Taphoorn MJ, Belanger K, Brandes AA, Marosi C, Bogdahn U (2005): Radiotherapy plus concomitant and adjuvant temozolomide for glioblastoma. N Engl J Med $\underline{352}$, 987-996

60. Thierry AR, Rabinovich P, Peng B, Mahan LC, Bryant JL, Gallo RC (1997): Characterization of liposome-mediated gene delivery: expression, stability and pharmacokinetics of plasmid DNA. Gene Ther 4, 226-237

61. Tye BK (1999): MCM proteins in DNA replication. Annu Rev Biochem $\underline{68}, 649-$ 686

62. Virchow R: Die krankhaften Geschwülste. Verlag von August Hirschwald, Berlin 1864-65

63. Wu Z, Asokan A, Samulski RJ (2006): Adeno-associated virus serotypes:

vector toolkit for human gene therapy. Mol Ther $\underline{14}, 316-327$

64.Zamore PD, Tuschl T, Sharp PA, Bartel DP (2000): RNAi: double-stranded RNA directs the ATP-dependent cleavage of mRNA at 21 to 23 nucleotide intervals. Cell 101, 25-33 